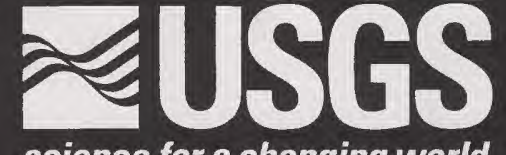

Prepared in cooperation with the

City of Spearfish, South Dakota

\title{
Hydrogeologic Characterization of the Minnelusa and Madison Aquifers near Spearfish, South Dakota
}

Water-Resources Investigations Report 98-4156
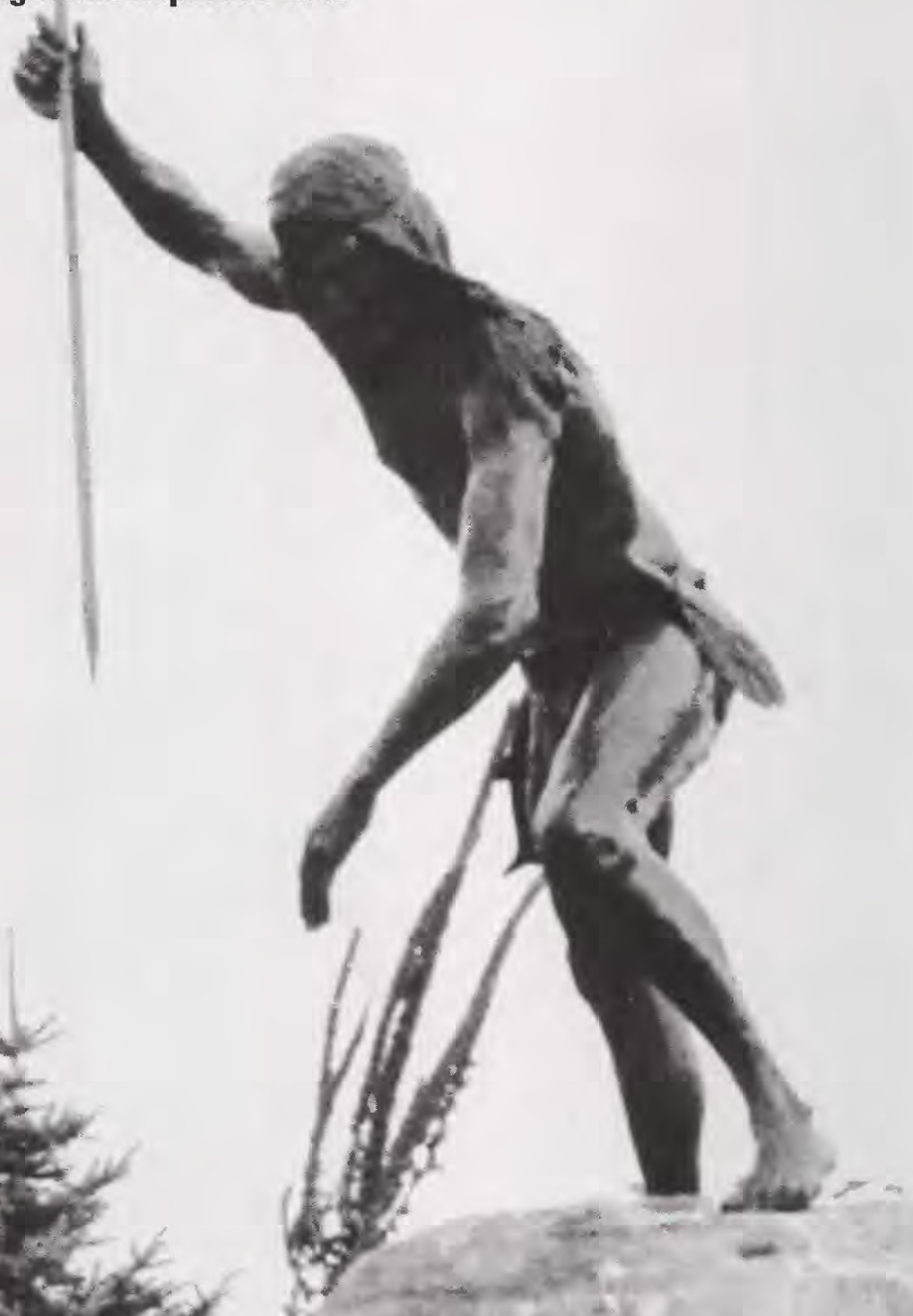
Cover photograph: Statue in Spearfish. Statue was created by T.R. Chytka.

Photograph by D.L. Rahder. 


\section{Hydrogeologic Characterization of the Minnelusa and Madison Aquifers near Spearfish, South Dakota}

By Earl A. Greene, Allen M. Shapiro, and Janet M. Carter

Water-Resources Investigations Report 98-4156 
U.S. Department of the Interior

Bruce Babbitt, Secretary

U.S. Geological Survey

Charles G. Groat, Director

Rapid City, South Dakota: 1999

For additional information, write to:

District Chief

U.S. Geological Survey

1608 Mt. View Road

Rapid City, SD 57702

Copies of this report can be purchased from:

U.S. Geological Survey

Branch of Information Services

Box 25286

Denver, CO 80225-0286 


\section{CONTENTS}

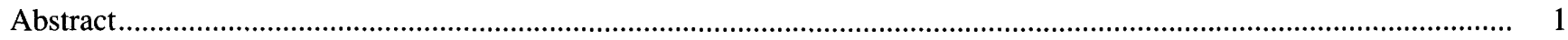

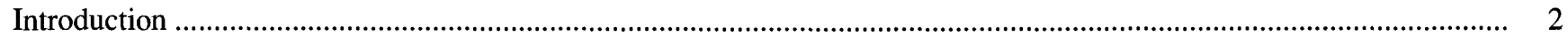

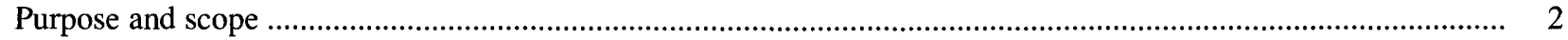

Previous investigations ………………………………………………………………………………… 5

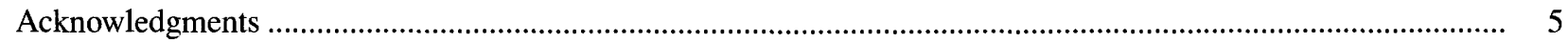

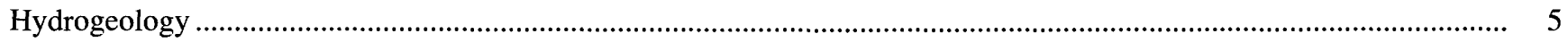

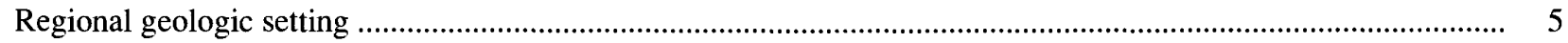

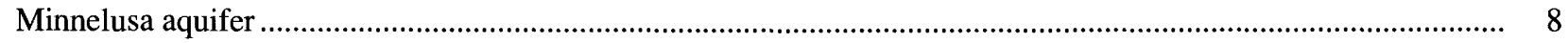

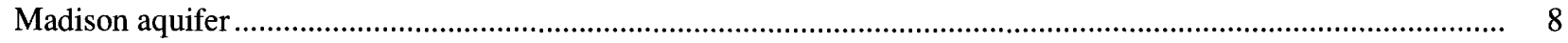

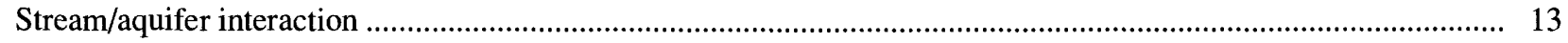

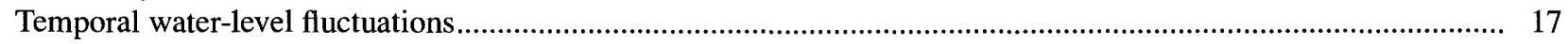

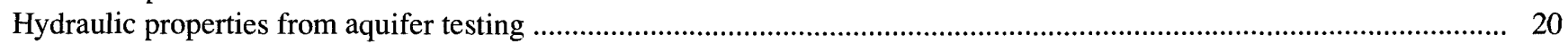

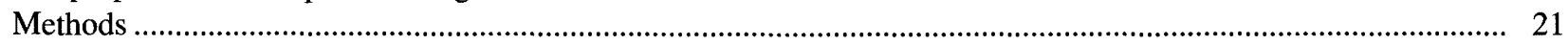

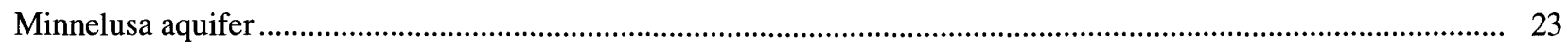

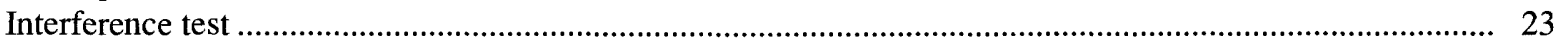

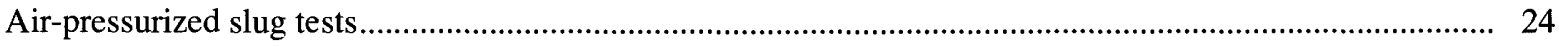

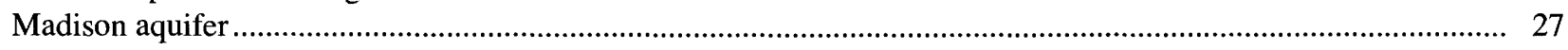

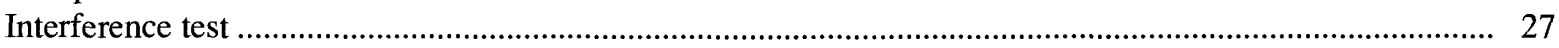

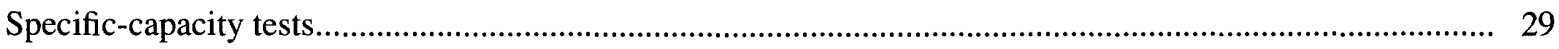

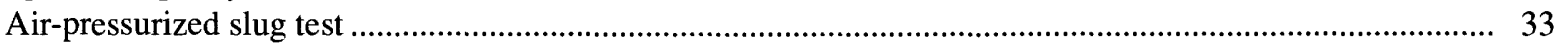

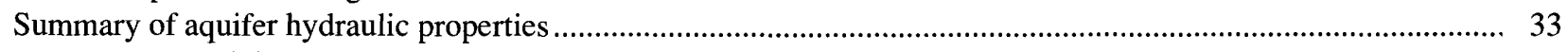

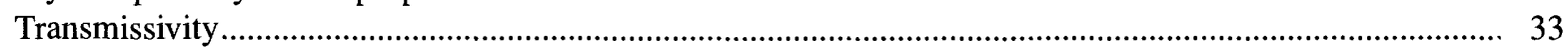

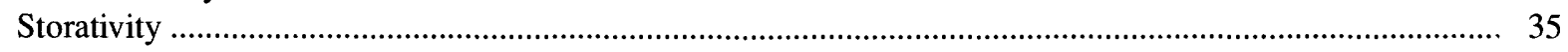

Synthesis of hydrologic information ………………………………………………………………………... 35

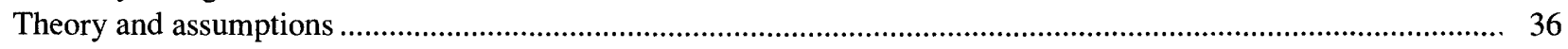

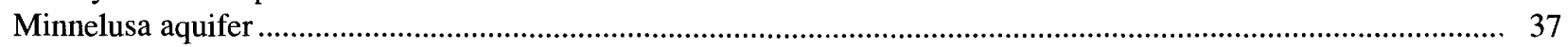

Model domain, boundary conditions, and parameter values ........................................................................ 37

Model discretization ……………………………………………………………………………... 39

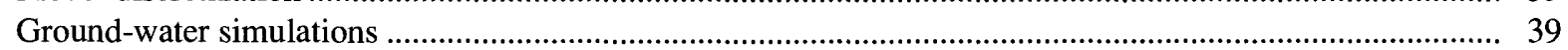

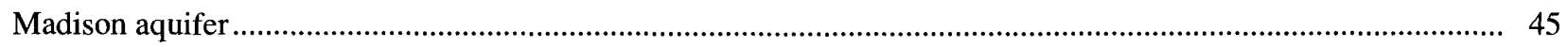

Model domain, boundary conditions, and parameter values .................................................................... 45

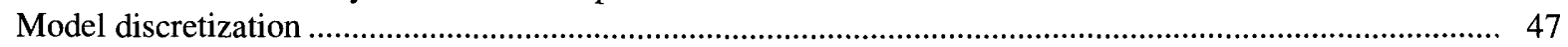

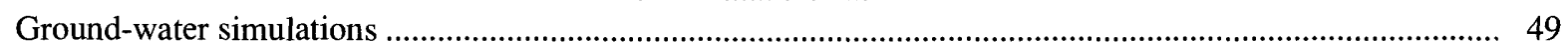

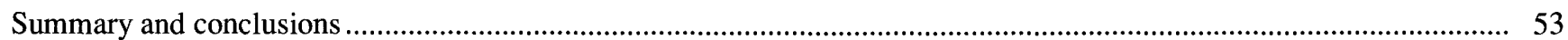

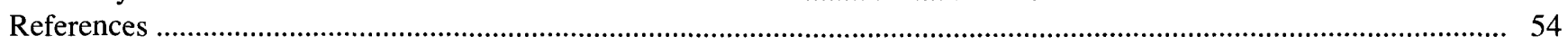

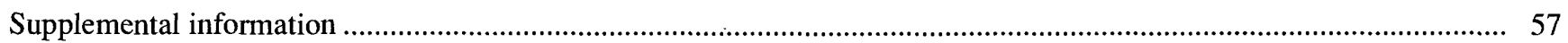

\section{ILLUSTRATIONS}

1. Map showing location of study area

2. Map showing locations of Spearfish's production wells, State observation wells, and USGS streamflow-gaging stations

3. Well-numbering system

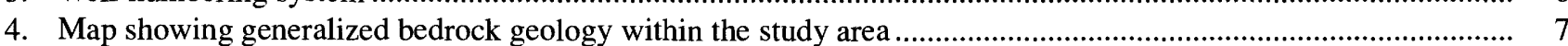

5. Map showing structure contours and major structural features .............................................................................. 9

6. Orientation of dip of bedrock and major structural features near Spearfish ........................................................ 10

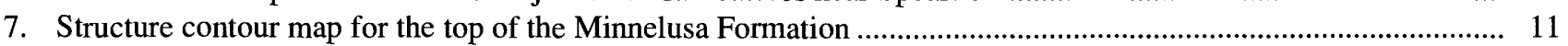

8. Potentiometric surface map of the Minnelusa aquifer, 1993 ............................................................................ 12 


\section{ILLUSTRATIONS-Continued}

9. Caliper and acoustic-televiewer logs for the upper part of the Madison aquifer in the Ellingson well ......

10. Caliper and acoustic-televiewer logs for the upper part of the Madison aquifer in the Kyte well.

11. Potentiometric surface map of the Madison aquifer, 1993.

12. Geologic cross sections along aqueduct

13. Long-term hydrographs for two wells completed in the Minnelusa aquifer

14. Graphs showing comparison of streamflow in Spearfish Creek above the Madison Limestone outcro? (06430900) and below (06431500) for 2 years of record

15. Hydrographs for observation wells LA-88B and LA-88C.

16. Graph showing comparison of streamflow and aquifer hydrographs for Spearfish Creek and observation well LA-88C

17. Map showing locations of wells used for hydraulic testing in the study area.....

18. Graph showing best fit type curve match to the drawdown data for observation well LA-88B from pumping the golf course well

19. Graph showing best fit type curve match to the drawdown data from the air-pressurized slug test conducted in observation well LA-87B using an applied air pressure of 6.5 pounds per square inch

Graphs showing best fit type curve match to the drawdown data from the air-pressurized slug test conducted in observation well LA-88B using an applied air pressure of a) 30 , b) 12 , and

c) 5 pounds per square inch.

21. Graphs showing best fit type curve match to the drawdown data from the air-pressurized slug tests conducted in observation well LA-88A at a) $100 \%$, b) $61 \%$, and c) $43 \%$ of the equilibrium water level, using an applied air pressure of 5 pounds per square inch.

22. Graph showing best fit type curve match to the drawdown data obtained at the Kyte well from the Dickey well interference test in the Madison aquifer.

23. Diagram showing conceptual model of ground-water flow to a well pumping in a unit consisting of solutional openings and a network of diffuse fractures...

24. Graphs showing step-drawdown test conducted in the Nevin well a) time versus drawdown data for a given pumping rate and $b$ ) determination of the turbulent head loss coefficient, $C$.

25. Graphs showing best fit type curves to the drawdown data from air-pressurized slug tests conducted in observation well LA-88B at a) $56 \%$ and b) $87 \%$ of the equilibrium water level, using an applied air pressure of 4.1 pounds per square inch .

26. Map showing model domain for the Minnelusa aquifer

27. Map showing finite-difference grid for numerical simulation of ground-water flow in the Minnelusa aquifer ........

28. Diagram showing distribution of transmissivity and recharge to reproduce the measured potentiometric surface of the Minnelusa aquifer.

29. Measured and simulated potentiometric surfaces for the Minnelusa aquifer (simulation used a recharge rate of 90,000 cubic feet per day and the distribution of transmissivity shown in figure 28)

30. Diagram showing distribution of transmissivity to reproduce the measured potentiometric surface of the Minnelusa aquifer after increasing the recharge rate by $25 \%$ to 112,500 cubic feet per day ......

1. Measured and simulated potentiometric surfaces for the Minnelusa aquifer (simulation used a recharge rate increased by $25 \%$ and a distribution of transmissivity increased by $25 \%$ as shown in figure 30 )

2. Map showing model domain for the Madison aquifer

33. Map showing finite-difference grid for numerical simulation of ground-water flow in the Madison a auifer ..

34. Diagram showing distribution of recharge, ground-water pumping, and transmissivity to reproduce the measured potentiometric surface of the Madison aquifer

5. Comparison of the measured and simulated potentiometric surfaces for the Madison aquifer using the distribution of stream recharge, ground-water pumping, and transmissivity shown in figure 34

36. Comparison of the measured and simulated potentiometric surfaces for the Madison aquifer using the distribution of stream recharge, ground-water pumping, and transmissivity shown in figure 34 , except with recharge from False Bottom Creek increased to 64,800 cubic feet per day ..... 


\section{TABLES}

1. Daily net losses of water along Spearfish Creek into the Minnelusa Formation and Madison Limestone between the upstream and downstream gaging sites .

2. Transmissivity $(T)$ and storativity $(S)$ estimates from type-curve matches to recovery data collected during air-pressurized slug tests conducted in observation wells LA-88A, LA-88B, and LA-87B near Spearfish, S. Dak.

3. Estimated transmissivity from analysis of specific-capacity tests completed in the College, Dickey, Ellingson, and Nevin wells

4. Summary of hydraulic properties from aquifer tests conducted in the Minnelusa and Madison aquifers near Spearfish, S. Dak.

5. Average ground-water withdrawals from production wells completed in the Madison aquifer in the vicinity of Spearfish, S. Dak.

6. Data for interference test at golf course well

7. Data for air-pressurized slug test at observation well LA-87B...

8. Data for air-pressurized slug tests at observation well LA-88B for applied pressures of 5,12 , and 30 pounds per square inch

9. Data for air-pressurized slug tests at observation well LA-88A for 100,61 , and 43 percent of the equilibrium water level, using an applied air pressure of 5 pounds per square inch.

10. Data for interference test at Dickey well

11. Data for air-pressurized slug tests at observation well LA-88C for 87 and 56 percent of the equilibrium water level, using an applied air pressure of 4.1 pounds per square inch.

\begin{tabular}{rll}
\hline Multiply & \multicolumn{1}{c}{ By } & To obtain \\
\hline cubic foot per second $\left(\mathrm{ft}^{3} / \mathrm{s}\right)$ & 0.02832 & cubic meter per second \\
cubic foot per day $\left(\mathrm{ft}^{3} / \mathrm{d}\right)$ & 0.02832 & cubic meter per day \\
foot $(\mathrm{ft})$ & 0.3048 & meter \\
foot squared per day $\left(\mathrm{ft}^{2} / \mathrm{d}\right)$ & 0.09290 & meter squared per day \\
foot squared per day $\left(\mathrm{ft}^{2} / \mathrm{d}\right)$ & $1.075 \times 10^{-6}$ & meters squared per second \\
gallon per minute $\left(\mathrm{gal} / \mathrm{min}^{-}\right)$ & 0.06309 & liter per second \\
inch $(\mathrm{in})$. & 2.54 & centimeter \\
inch $(\mathrm{in})$. & 25.4 & millimeter \\
inch per year $\left(\mathrm{in} / \mathrm{yr}^{2}\right)$ & 25.4 & millimeter per year \\
mile $\left(\mathrm{mi}^{2}\right)$ & 1.609 & kilometer \\
million gallons per day $(\mathrm{Mgal} / \mathrm{d})$ & 0.04381 & cubic meter per second \\
pound per square inch $\left(\mathrm{lb} / \mathrm{in}^{2}\right)$ & 6.895 & kilopascal \\
pound per square inch $\left(\mathrm{lb} / \mathrm{in}^{2}\right)$ & 6,895 & pascal \\
square mile $\left(\mathrm{mi}^{2}\right)$ & 259.0 & hectare \\
square mile $\left(\mathrm{mi}^{2}\right)$ & 2.590 & square kilometer \\
\hline
\end{tabular}

Sea level: In this report, "sea level" refers to the National Geodetic Vertical Datum of 1929 (NGVD of 1929) - a geodetic datum derived from a general adjustment of the first-order level nets of both the United States and Canada, formerly called Sea Level Datum of 1929.

Water year: In Geological Survey reports dealing with surface-water supply, water year is the 12-month period, October 1 through September 30. The water year is designated by the calendar year in which it ends; thus, the water year ending September 30. 1994, is called the "1994 water year." 
. 


\title{
Hydrogeologic Characterization of the Minnelusa and Madison Aquifers near Spearfish, South Dakota
}

\author{
By Earl A. Greene, Allen M. Shapiro, and Janet M. Carter
}

\section{ABSTRACT}

The hydrogeology of the Minnelusa and Madison aquifers near Spearfish, South Dakota, was characterized in a 3-year study to determine the spatial distribution of the transmissivity and storativity of the aquifers. Numerical modeling was conducted to synthesize the known hydrologic information and illustrate where additional information is needed to better characterize the Minnelusa and Madison aquifers for management of the ground-water resources.

The general direction of ground-water flow in the Minnelusa and Madison aquifers is from the outcrops (south of Spearfish) northward. The hydraulic gradient of the aquifers is steepest near the outcrops and decreases northward. Mapped structural features in the vicinity of the Spearfish coincide with low hydraulic gradients of the potentiometric surface indicating zones of high hydraulic conductivity. Hydrographs of water levels in the Minnelusa and Madison aquifers show a direct response to recharge from snowmelt runoff and precipitation.

Transmissivities estimated from aquifer tests conducted in the Minnelusa and Madison aquifers are affected by the scale of the formation stressed by the particular aquifer test. Aquifer tests that stressed a larger area of the aquifer $(1,000$ to $2,000 \mathrm{ft})$ generally showed a higher estimate of transmissivity than the tests that stressed only a few feet around the borehole. This illustrates the heterogeneity present in the Minnelusa and Madison aquifers. Consequently the results of aquifer tests may only provide information pertinent to the immediate vicinity around the well and may not provide estimates of aquifer properties needed to characterize regional ground-water flow.

Numerical simulation of steady-state ground-water flow in the aquifers provided an understanding of recharge, the relation between transmissivity and recharge, and the role that geologic structures play in controlling ground-water movement. Using estimated values of recharge and ground-water withdrawals for the aquifers, the general characteristics of the measured potentiometric surfaces can be reproduced by a spatial distribution of the transmissivity. To obtain the large spatial variations in the mapped potentiometric surface measured in the Minnelusa aquifer, transmissivity values varied over several orders of magnitude, with high transmissivity zones refresenting the location of the mapped structural features. In the Madison aquifer, a simple spatial distribution in transmissivity reproduced the characteristics of the measured potentiometric surface, with lower transmissivity near the outcrop and higher transmissivity northward. In general, for both aquifers the transmissivity toward the northern part of the model domain is more than an order of magnitude larger than transmissivity near the outcrop. 
Recharge rates used in the simulation of hydraulic heads in the Minnelusa and Madison aquifers are only estimates and the actual recharge rates could be larger or smaller. For both aquifers, the measured hydraulic heads could be simulated by changing estimates of recharge and transmissivity; thus, accurate estimates of recharge are needed to estimate regional transmissivities and characterize regional ground-water movement in the Minnelusa and Madison aquifers in the Spearfish area. The management of the groundwater resources in the Spearfish area will require improved estimates of recharge in order to improve estimates of regional transmissivity.

\section{INTRODUCTION}

The Madison aquifer in the northern Black Hills area currently is being developed as the main source of municipal water for the residents of the City of Spearfish, S. Dak. As a result of the growing population, an increased demand is being placed on the ground-water resources. The Minnelusa aquifer is a major source of water for domestic and stock use in the Spearfish area and potentially is a principal source of water for municipal use. Even though the Minnelusa aquifer is more developed than the Madison aquifer in the study area, its hydraulic properties are still poorly understood, and the ability to supply sufficient water for municipal use is unknown. Current knowledge on the hydrogeology of the Madison aquifer in this area is minimal. Therefore, additional knowledge about the hydrogeology and information on the long-term availability of water is needed to formulate sound groundwater management plans and to make future regulatory decisions.

The U.S. Geological Survey (USGS) has been cooperating with Federal agencies, State of South Dakota, Rapid City, West Dakota Water Development District, and others since the early 1980 's to develop an understanding of the hydrogeology of the Minnelusa and Madison aquifers in western South Dakota. From 1992-95, the USGS, in cooperation with the City of Spearfish, conducted a study to characterize the general hydrogeology and the hydraulic properties of the Minnelusa and Madison aquifers in the Spearfish area (fig. 1).

\section{Purpose and Scope}

The purpose of this report is to present the results of a 3-year study to characterize the hydrogeology and describe the hydraulic properties of the Minnelusa and Madison aquifers in the Spearfish area. In addition, the hydrogeology of the aquifers is synthesized through a numerical model of ground-water flow.

Several methods of investigation were used to characterize the hydraulic properties and investigate the availability of water from the Minnelusa and Madison aquifers in the Spearfish area. Results of previously published studies and data from existing wells in the area were used to evaluate the extent and nature of the aquifers, including aquifer thickness and depth below land surface, and to map the potentiometric surface. In addition, temporal water-level fluctuations were analyzed at observation vrells completed in the Minnelusa and Madison aquifers.

Streamflow records were analyzed at two streamflow-gaging stations along Spearfish Creek (fig. 2). The hydrographs of streamflow upstream of the outcrops of the Minnelusa Formation and Madison Limestone and downstream from the outcrops were compared to estimate streamflow loss to the aquifers.

Borehole geophysical logging at city production wells (Vigna, Kyte, and Ellingson) (fig. 2) was used to investigate and define the physical properties of the Madison aquifer, especially the role of enhanced secondary porosity in controlling ground-water movement in the fractured and karst Madiscn Limestone. Analysis of geophysical logs provided information on the location and orientation of fractures, including the character of the karst features.

Aquifer tests consisting of multiple-well (interference) tests, specific-capacity tests, and slug tests were conducted at several wells complated in the Minnelusa and Madison aquifers to determine the transmissivity and storativity of the formations. Interference tests were conducted in the Minnelusa and Madison aquifers. Single-well constant-discharge (specific-capacity) tests were conducted in the Madison aquifer at the Ellingson, Colloge, and Kyte wells. Air-pressurized slug tests were conducted at three observation wells completed in the Minnelusa aquifer (LA-88A, LA-88B, LA-87B), and at one observation well completed in the Madison aquifer (LA-88C) (fig. 2). Numerical modeling of the Minnelusa and Madison aquifers in the Spearfish area was conducted to synthesize the available rydrologic information and illustrate where additional information is needed to characterize regional ground-water flow. 


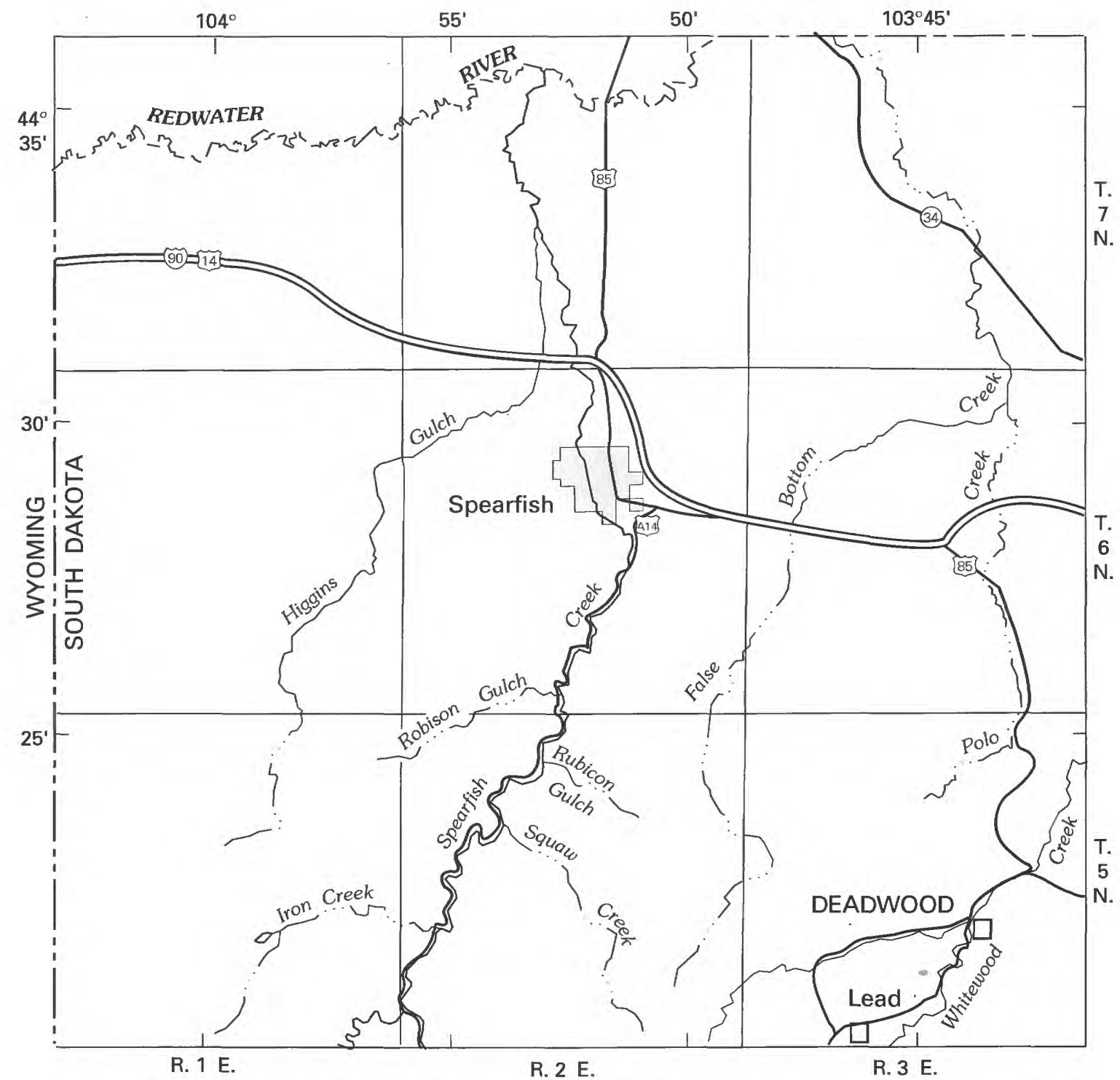

Base from U.S. Geological Survey State base map, 1:500,000. Drainage from Digital Line Graph, 1:100,000 and U.S. Geological Survey quadrangles, 1:24,000

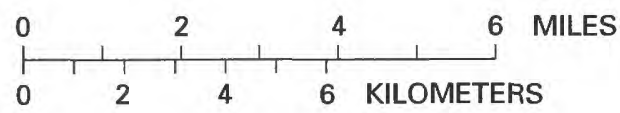

\section{MILES}

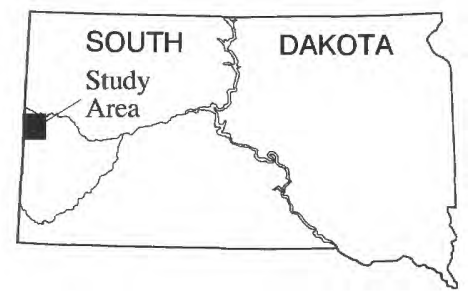

Figure 1. Location of study area. 


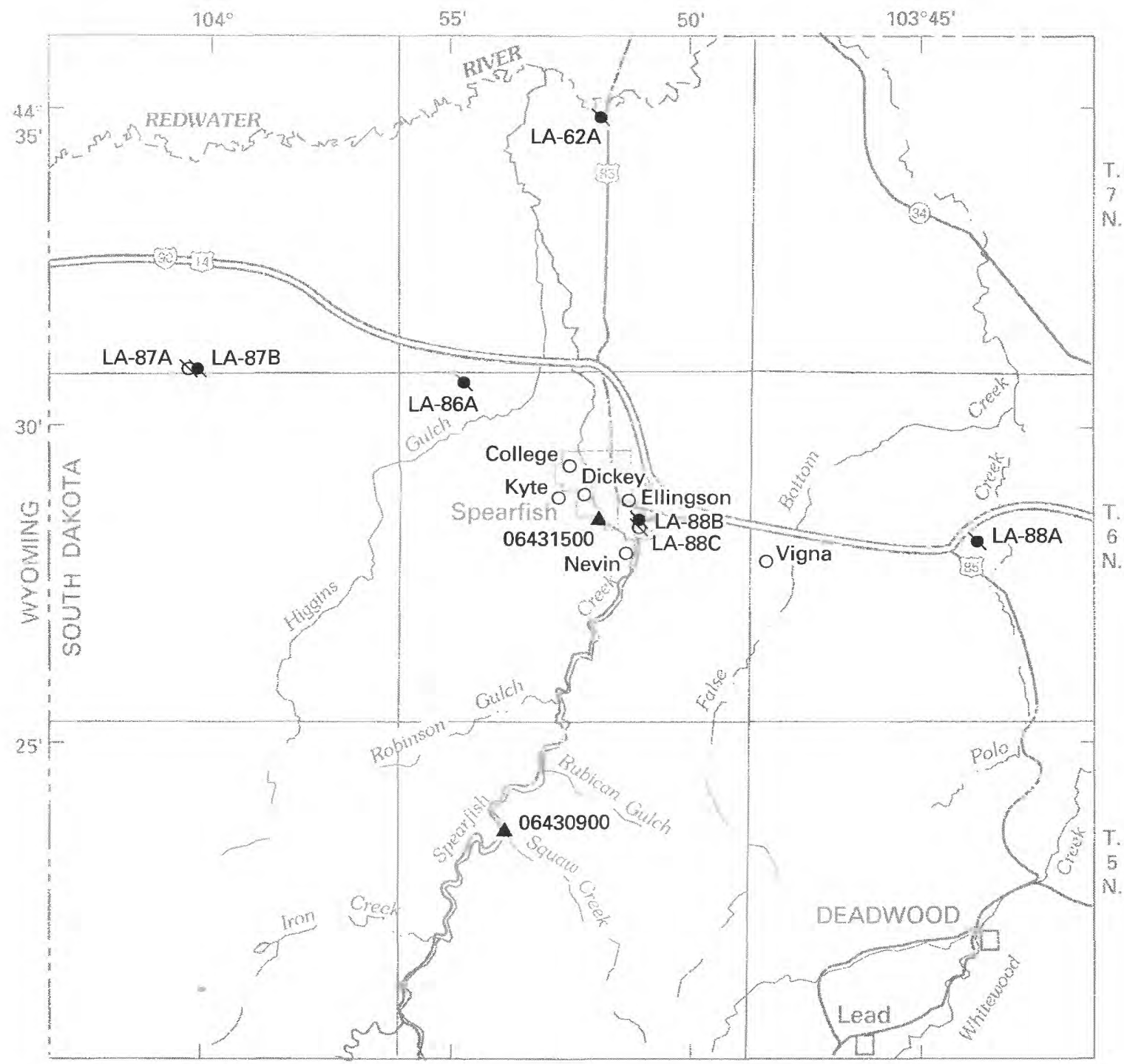

R. 1 E.

R. 2 E.

R. $3 E$.

Base from U.S. Geological Survey State base map, 1:500,000. Drainage from Digital Line Graph, 1:100,000 and U.S. Geological Survey quadrangles, 1:24,000

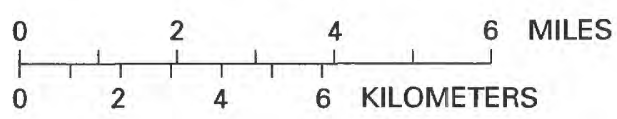

EXPLANATION

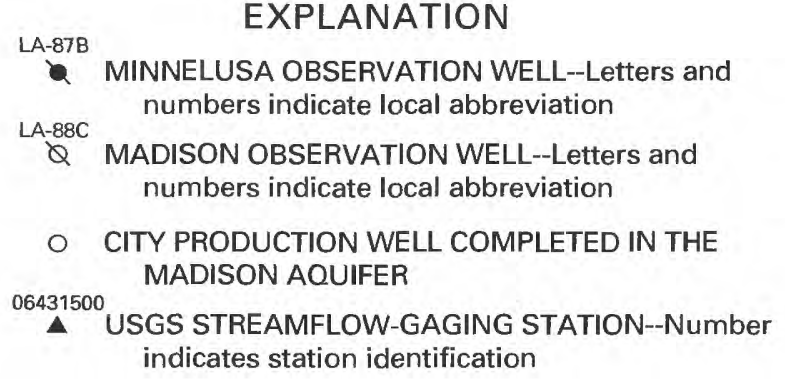

Figure 2. Locations of Spearfish's production wells, State observation wells, and USGS streamflow-gaging stations. 
Some well locations are referred to by their local number, which is based on the Federal land-survey system of western South Dakota (fig. 3). The local number consists of the township number followed by " $\mathrm{N}$," range number followed by " $\mathrm{E}$," and section number followed by a maximum of four uppercase letters that indicate, respectively, the 160-, 40-, 10-, and 2.5-acre tract in which the well is located. These letters are assigned in a counterclockwise direction beginning with " $A$ " in the northeast quarter. Thus, well $6 \mathrm{~N} 2 \mathrm{E} 23 \mathrm{BBBA}$ is in the NE1/4 of the NW1/4 of the NW1/4 of the NW1/4 of section 23 in township 6 north and range 2 east.

\section{Previous Investigations}

Many reports describe the general geology and hydrology of western South Dakota including the northern Black Hills area. The geology of the central and northern Black Hills was described by Darton and O'Harra (1905, 1909) and Darton and Paige (1925). A geologic map of the Black Hills area was presented by Dewitt and others (1989). Road logs by Rahn and others (1985) and Gries and Steece (1985) described the engineering geology and stratigraphy in the northern Black Hills. The geologic structure and altitude of the top of the Minnelusa Formation for the northeastern Black Hills was presented by Peter and others (1988).

A number of reports and papers have been published describing the ground-water resources of the northern Black Hills, but ground-water studies of the Spearfish area are limited. A ground-water inventory of the aquifers in western South Dakota, including the Madison and Minnelusa aquifers, was presented by Rahn (1985). Kyllonen and Peter (1987) presented a digital model of ground-water flow in the Inyan Kara, Minnelusa, and Madison aquifers of the northern Black Hills and Bear Lodge Mountains. They concluded that flow between the Minnelusa and Inyan Kara aquifers was not significant. Furthermore, the relation of leakage between the Minnelusa and Madison aquifers was not understood by the modeling effort. Greene and Rahn (1995) developed a field approach to identify localized anisotropy and characterize permeability resulting from modern karst superimposed on paleokarst in the Madison aquifer in the Spearfish area.

\section{Acknowledgments}

The authors thank Mr. Ted Vore and the employees of the City of Spearfish for their assistance during the aquifer tests and collection of hydraulic data. The South Dakota Department of Environment and Natural Resources provided access to their observation wells and water-level information. The authors also thank the U.S. Geological Survey Borehole Geophysical Research Project in Lakewood, Colorado, for their help in obtaining and interpreting geophysical logs of selected wells in Spearfish.

\section{HYDROGEOLOGY}

\section{Regional Geologic Setting}

The Black Hills uplift of western South Dakota and eastern Wyoming formed a north-northwestern trending elongated dome about 60 to 65 million years ago (DeWitt and others, 1986). The Black Hills uplift is about $120 \mathrm{mi}$ long and $60 \mathrm{mi}$ wide. Elevations range from 7,242 ft above sea level to about $3,000 \mathrm{ft}$ in the adjacent plains.

The core of the uplift is composed of hard, erosion-resistant undifferentiated Precambrian-age igneous and metamorphic rocks along with Precambrian- and Tertiary-age intrusive igneous rocks. Surrounding the Precambrian core are outcrops of Paleozoic-age strata, which primarily are bands of dipping limestones, interbedded sandstones, and shales. The Paleozoic-age sequence contains the formations that are most important for this study. The oldest sedimentary unit in the study area is the Cambrian-age Deadwood Formation, which is separated from the Mississippian-age Madison Limestone by several minor layers, including the Winnipeg Formation, Whitewood Formation, and the Englewood Limestone. The Pennsylvanian- and Lower Permian-age Minnelusa Formation unconformably overlies the Madison Limestone.

Above the Minnelusa Formation is the Lower Permian-age Opeche Shale and Minnekahta Limestone. The Quaternary-, Tertiary-, and Mesozoic-age rocks are considered confining beds to the Minnelusa and Madison aquifers. A generalized bedrock geology map for the study area (fig. 4) was constructed by modifying the geologic maps by Darton (1905), Darton and O'Harra (1905, 1909), Darton and Paige (1925), DeWitt and others, (1989), Lisenbee (1991a, 1991b, 1991c, 1991d, 1991e), and Lisenbee and Redden (1991). 


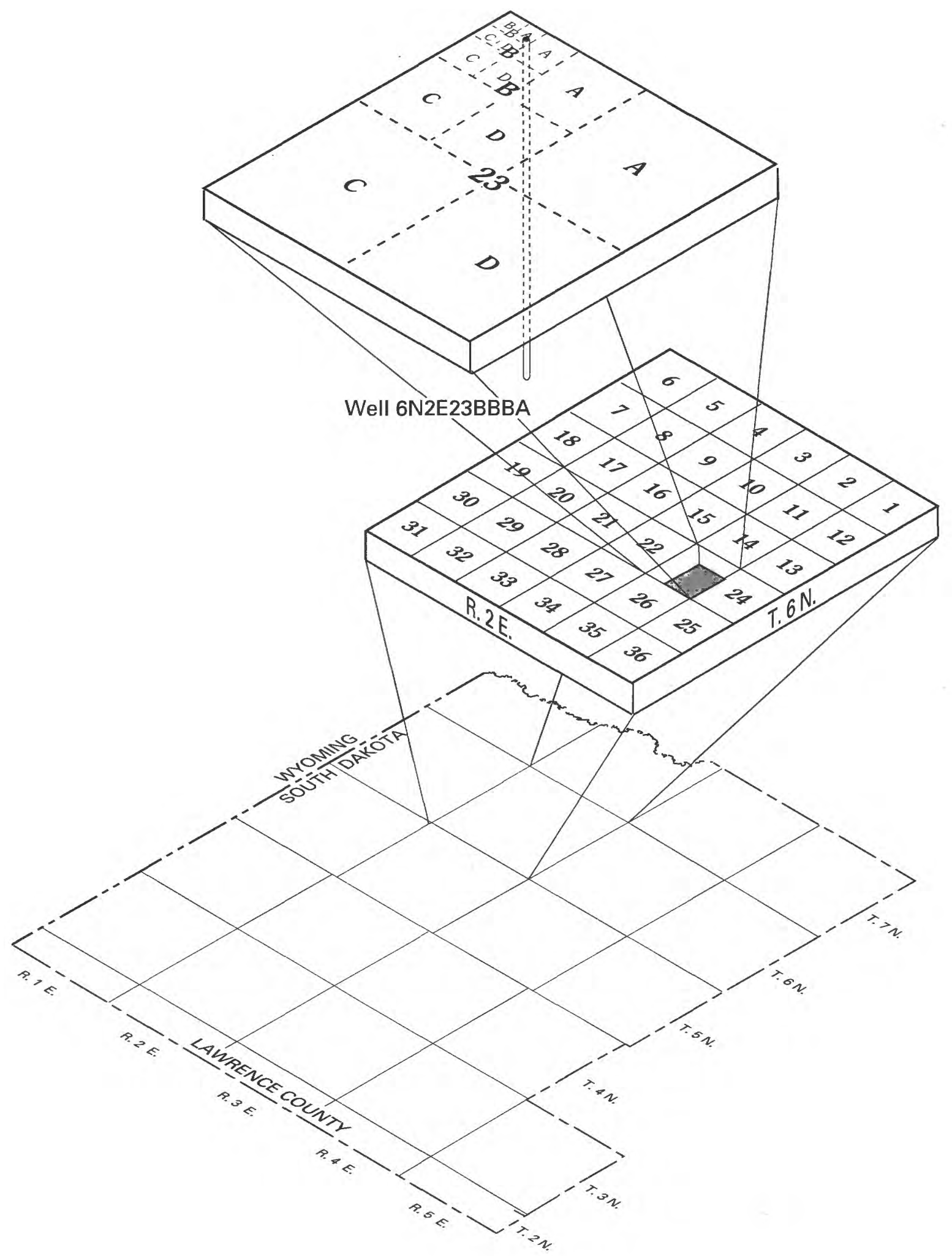

Figure 3. Well-numbering system. The well number consists of the township, followed by " $\mathrm{N}$," the range number followed by "E," and the section number, followed by a maximum of four uppercase letters that indicate, respectively, the 160-, 40-, 10-, and $21 / 2$-acre tract in which the well is located. These letters are assigned in a counterclockwise direction beginning with " $\mathrm{A}$ " in the northeast quarter. A serial number following the last letter is used to distinguish between wells in the same $21 / 2$-acre tract. 


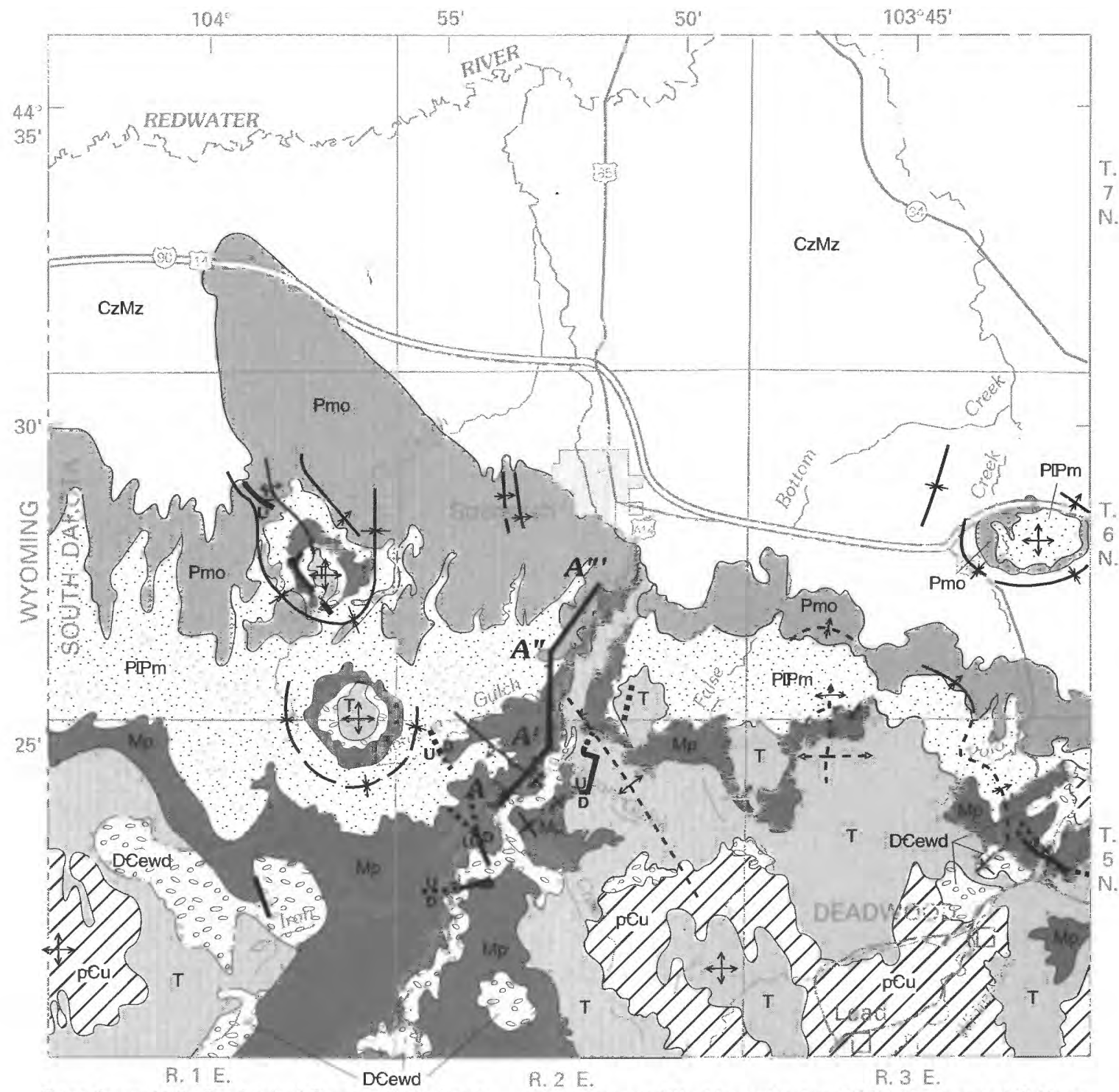

Base from U.S. Geological Survey State base map, 1:500,000. Drainage from Digital Line Graph, 1:100,000 and U.S. Geological Survey quadrangles, 1:24,000

Geology modified from Darton, 1905; Darton and O'Harra, 1905, 1909; Darton and Sidney Paige, 1925; DeWitt and others, 1989; Lisenbee, 1991a, 1991b, 1991c, 1991d, 1991e; and Lisenbee and Redden, 1991.

\section{EXPLANATION}

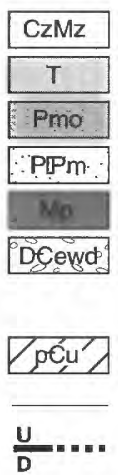

TERTIARY IGNEOUS ROCKS MINNELUSA FORMATION

MADISON LIMESTONE

\section{PRECAMBRIAN (undivided)}

\section{CONTACT}

CENOZOIC AND MESOZOIC ROCKS

MINNEKAHTA LIMESTONE AND OPECHE SHALE

DEADWOOD FORMATION, ENGLEWOOD LIMESTONE, WHITEWOOD DOLOMITE, AND WINNIPEG FORMATION

FAULT--"U"indicates upthrown side and "D" indicates downthrown side. Dashed where approximately located.

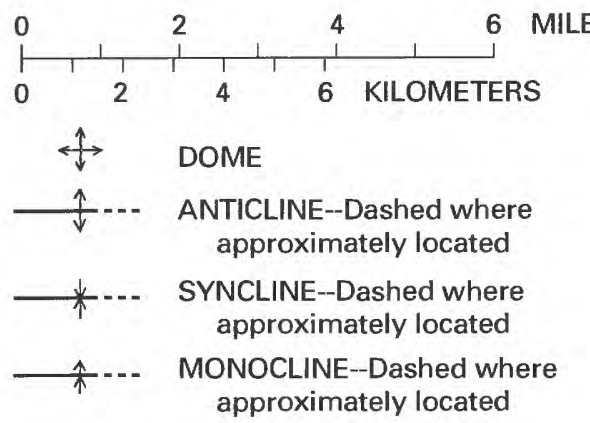

A $\boldsymbol{A}^{\prime \prime \prime}$ LINE OF GEOLOGIC SECTION-Shown in figure 12

Figure 4. Generalized bedrock geology within the study area. 
Regional structure of the bedrock in the Black Hills may control and have an influence on direction and magnitude of ground-water flow in the Minnelusa and Madison aquifers. However, the exact nature of structural controls (orientation, dip, and direction of the bedrock and structural features such as domes, faults, folds, anticlines, and synclines) on ground-water flow is not well defined in the study area. The regional structure of the bedrock in the Spearfish area is complicated by the tectonic event of the Black Hills uplift. Figure 5 (modified from Lisenbee, 1985) is a tectonic map of bedrock in the Spearfish area, and illustrates the complexity of structure in the study area. General dip of the bedrock is in a northeast direction (fig. 6). A number of major structural features (domes and anticlines) in the study area were mapped by Lisenbee (1985). Overall these features, such as the LaFlamme Anticline, are orientated in a northwest direction (fig. 6), but locally the Belle Fourche Anticline (northeast of Spearfish) is orientated in a northern direction and may control ground-water movement in this part of the study area.

\section{Minnelusa Aquifer}

The Minnelusa Formation is approximately $500 \mathrm{ft}$ thick in the study area, with the sandstones in the upper part of the formation containing the Minnelusa aquifer (Kyllonen and Peter, 1987). The Minnelusa Formation consists largely of alternating units of sandstone and dolomite interbedded with lesser amounts of shale and chert. The upper part of the formation contains dolomite, anhydrite, sandstone, siltstone, and cherty dolomite. The lower part of the Minnelusa Formation consists of interbedded dolomite and sandstone with lesser amounts of anhydrite and shale. The lower part of the Minnelusa Formation is a confining layer or semi-confining layer separating the Minnelusa aquifer from the Madison aquifer (Greene, 1993). A structure contour map of the top of the Minnelusa Formation in the Spearfish area was prepared for this study by modifying the work of Kyllonen and Peter (1987) to include additional information from wells drilled after 1985 (fig. 7). The location and orientation of the LaFlamme Anticline and Belle Fourche Anticline shown in figure 7 are similar to the tectonic map of the Black Hills area (fig. 5) developed by Lisenbee (1985). Figure 7 shows that the Minnelusa Formation crops out at an elevation of about $4,100 \mathrm{ft}$ above sea level in the southern part of the study area and generally dips at a 5-percent slope to an elevation of about 1,800 ft above sea level near the northern boundary of the study area.

The Minnelusa aquifer usually is contained within the upper part of the formation in relatively thick zones of poorly cemented sandstones. From analysis of geophysical logs of the Minnelusa Formation, the aquifer is contained within the upper 200 to $300 \mathrm{ft}$ of the formation (Greene, 1993). The Minnelusa aquifer probably has a similar thickness in the Spearfish area (Kyllonen and Peter, 1987).

Water-level measurements in 1993 from approximately 75 wells completed within the Minnelusa aquifer throughout the study area were used to map a potentiometric surface (fig. 8). The general direction of ground-water flow is from south to north. The hydraulic gradient of the Minnelusa aquifer is the steepest near the outcrop of the Minnelusa Formation and gradually decreases north of Spearfish. Three areas stand out as zones of low hydraulic gradient and coincide with the mapped structural features of the Belle Fourche Anticline, LaFlamme Anticline, and the unnamed monocline that is to the northwest of Spearfish. The low hydraulic gradient, or equivalently the large distance between potentiometric contours, along these structural features probably indicates zones of high hydraulic conductivity.

\section{Madison Aquifer}

The Madison Limestone is a major cliff-forming unit with a composition varying from pure limestone to pure dolomite, including various combinations of the two (Shapiro and Gries, 1968). The Madison Limestone commonly is referred to as the Pahasapa Limestone in the Black Hills region.

The Madison Limestone forms a very large and extensive aquifer surrounding the Black Hills. Much of the regional permeability is associated with karstification at the end of the Mississippian period. However, during post-Larimide time, as the Black Hills was uplifted, karstification was renewed and this increased permeability has been superimposed on the Mississippian karst development (Greene and Rahn, 1995). Rahn and Gries (1973) showed that streams lose some or all of their flow as they cross the outcrop of the Madison Limestone, only to have recharge waters resurface at springs in a different watershed. 


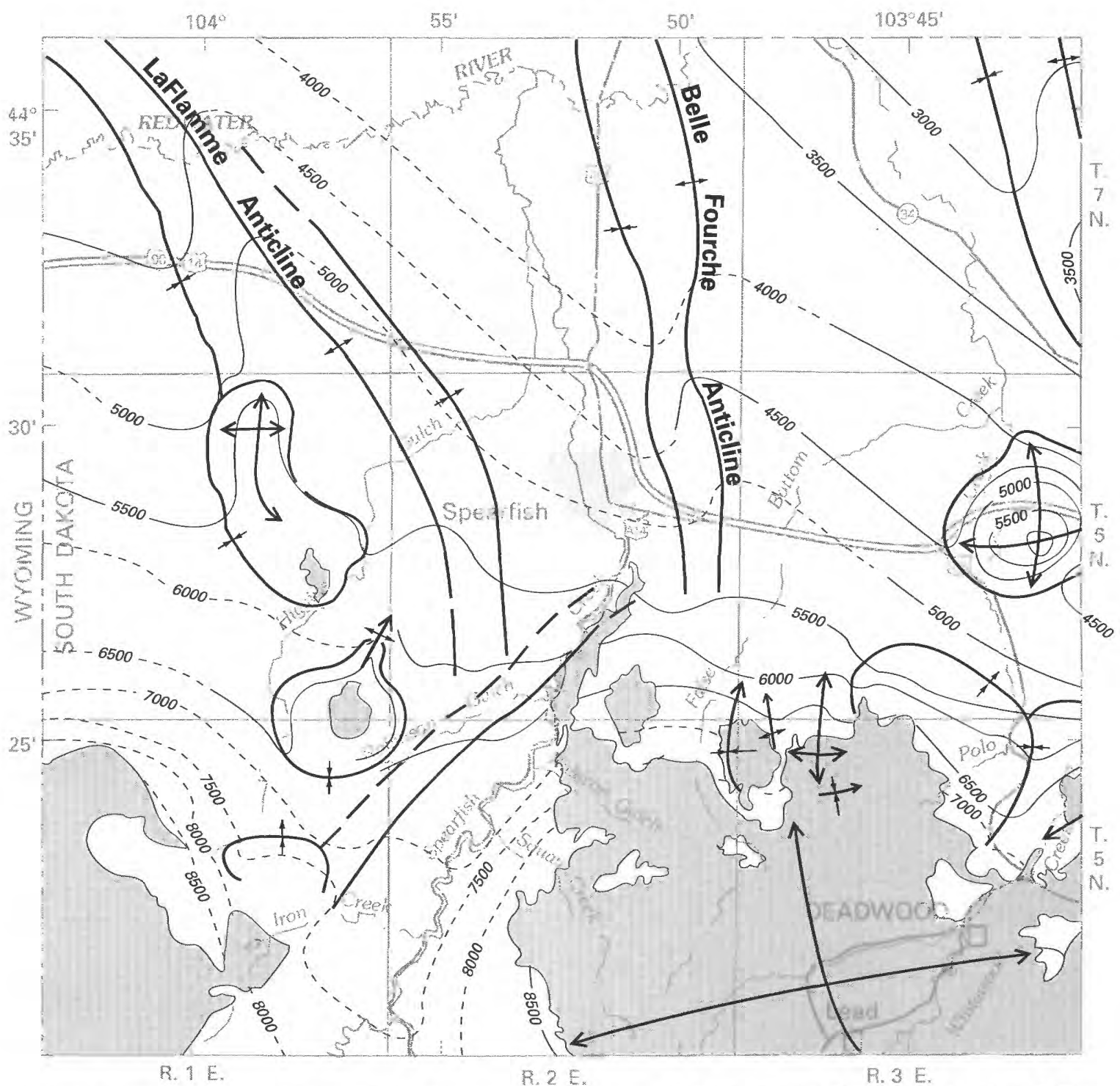

Base from U.S. Geological Survey State base map, 1:500,000. Drainage from Digital Line Graph, 1:100,000 and U.S. Geological Survey quadrangles, 1:24,000

Structures modified from Lisenbee, 1985

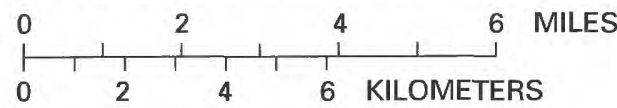

EXPLANATION

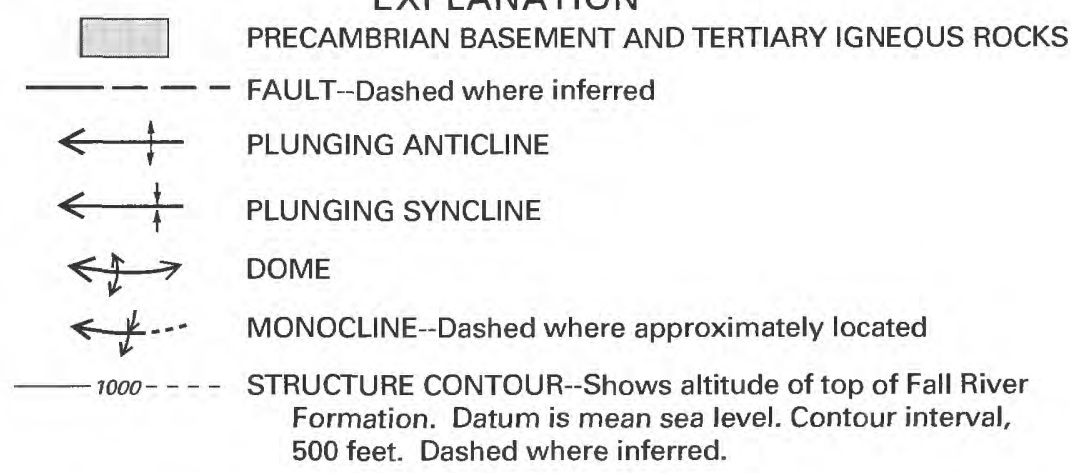

Figure 5. Structure contours and major structural features. 


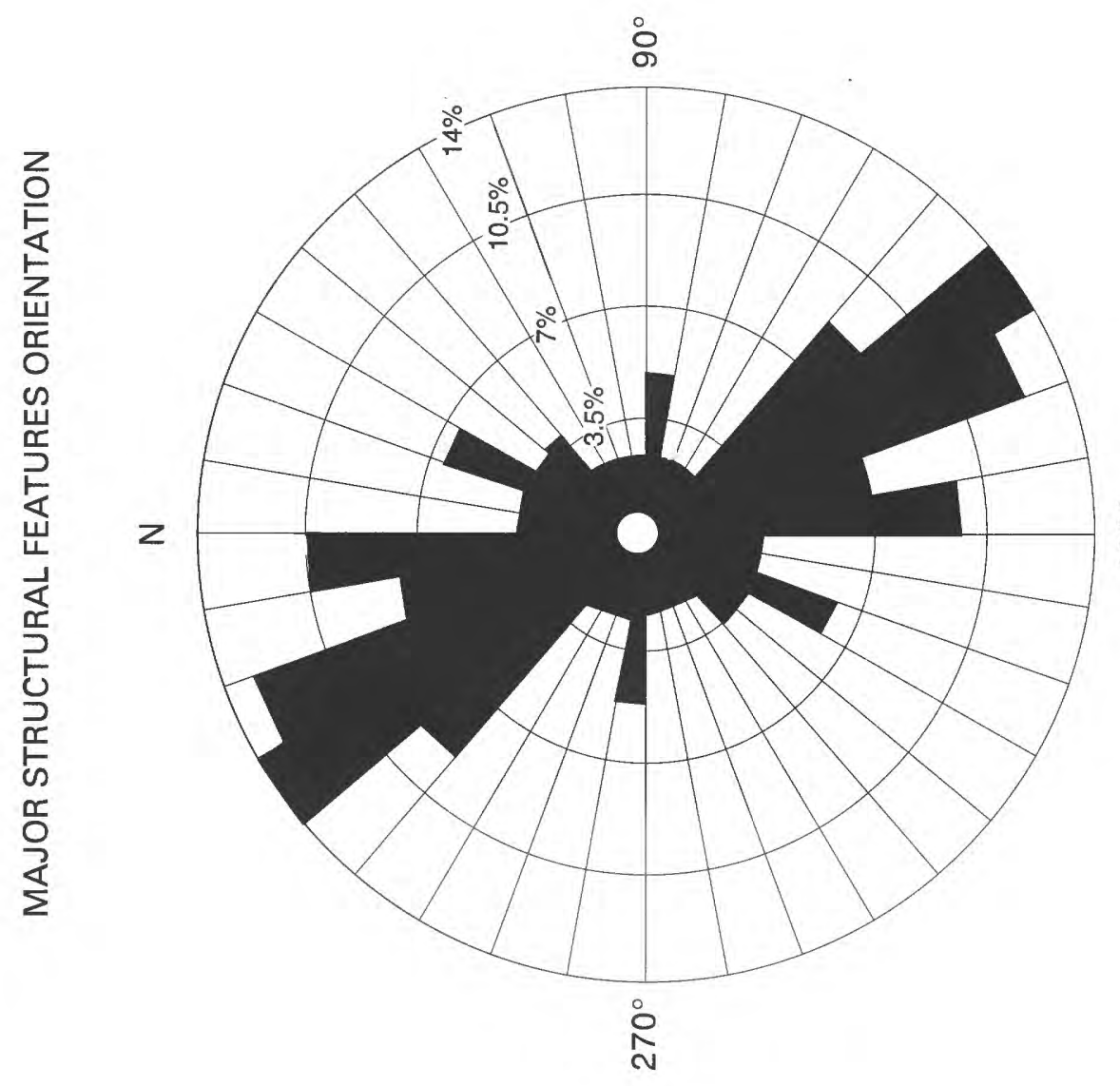

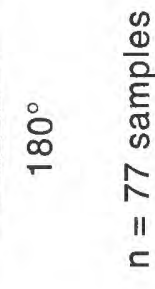

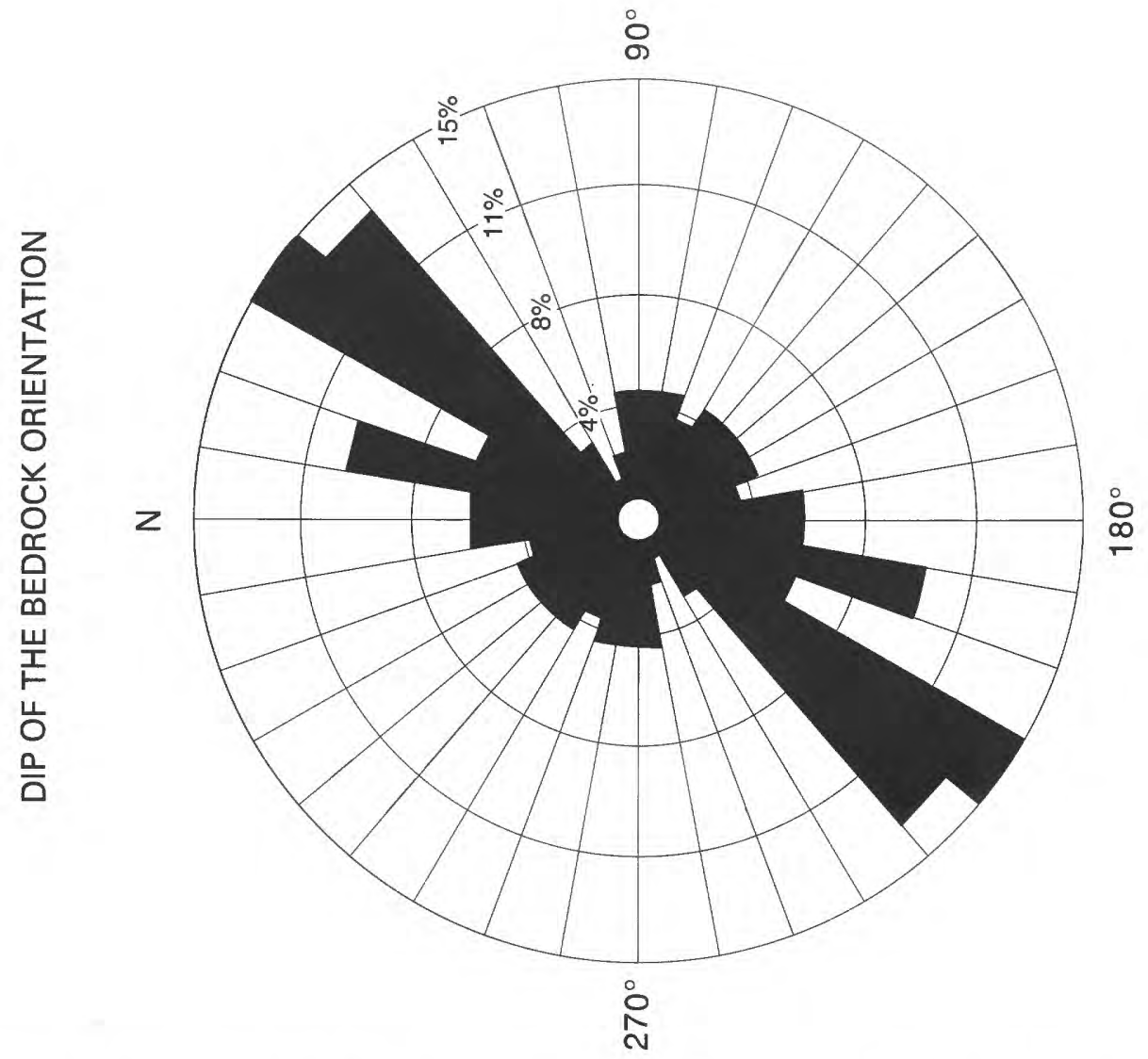

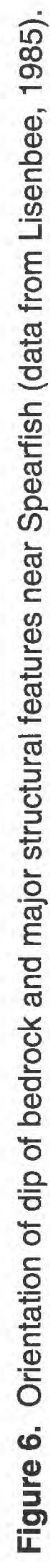




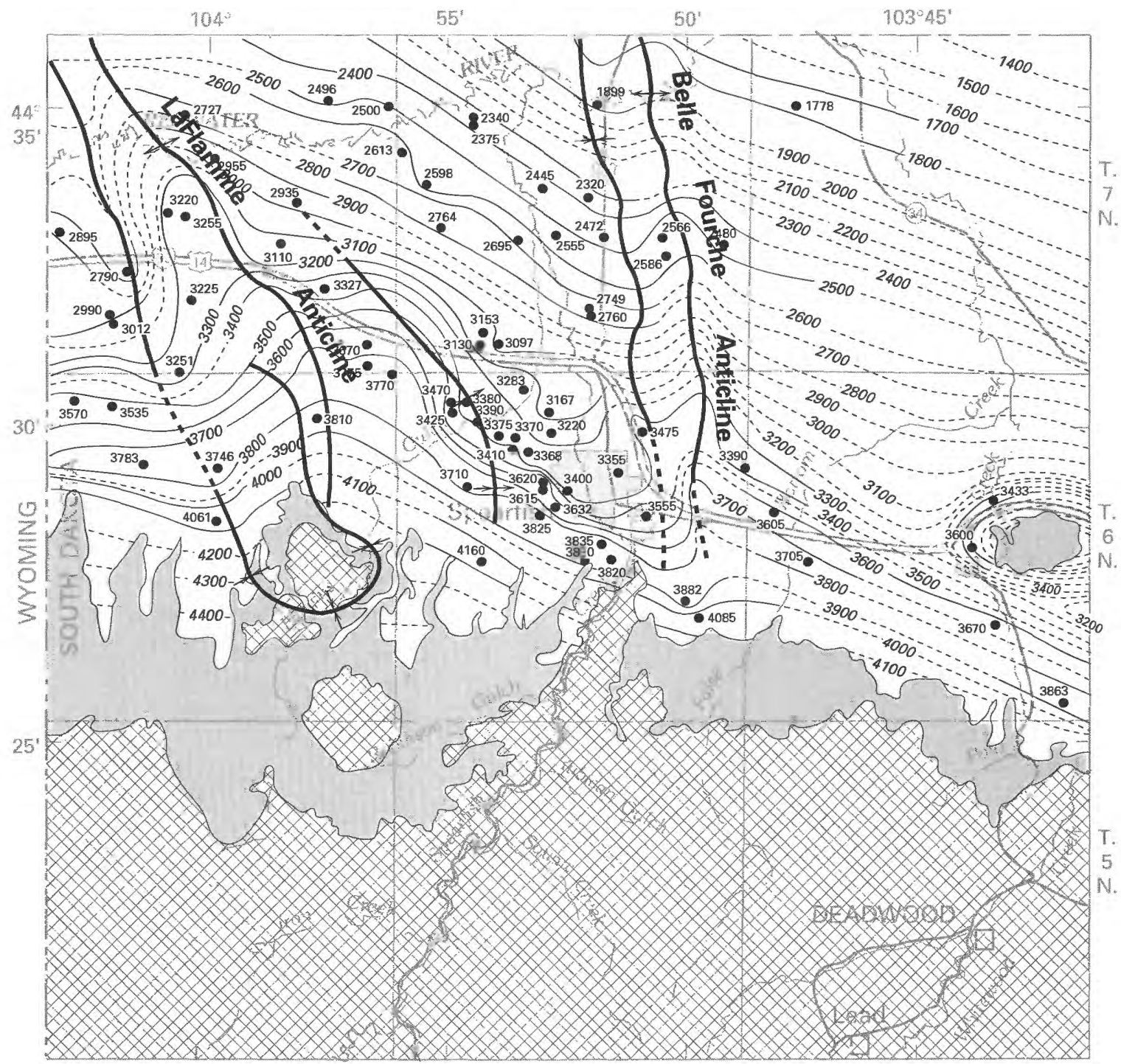

R. $1 E_{\text {. }}$

Base from U.S. Geological Survey State base map, 1:500,000. Drainage from Digital Line Graph, 1:100,000 and U.S. Geological Survey quadrangles, 1:24,000
R. 2 E.
R. $3 E$.

Contours and structures modified from Kyllonen and Peter, 1987

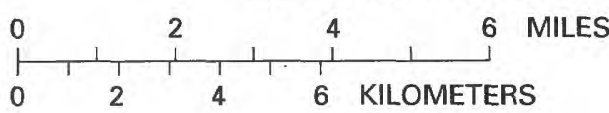

\section{EXPLANATION}

\section{OUTCROP OF THE MINNELUSA FORMATION}

\section{MINNELUSA FORMATION ABSENT}

\section{- 3000 --. STRUCTURE CONTOUR--Shows altitude of top of} Minnelusa Formation. Dashed where approximately located. Contour interval, 100 feet. Datum is sea level.

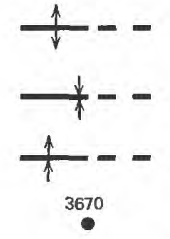

ANTICLINE--Dashed where approximately located SYNCLINE--Dashed where approximately located MONOCLINE--Dashed where approximately located WELL COMPLETED IN THE MINNELUSA AQUIFER--Number is altitude of the top of the Minnelusa Formation

Figure 7. Structure contour map for the top of the Minnelusa Formation. 


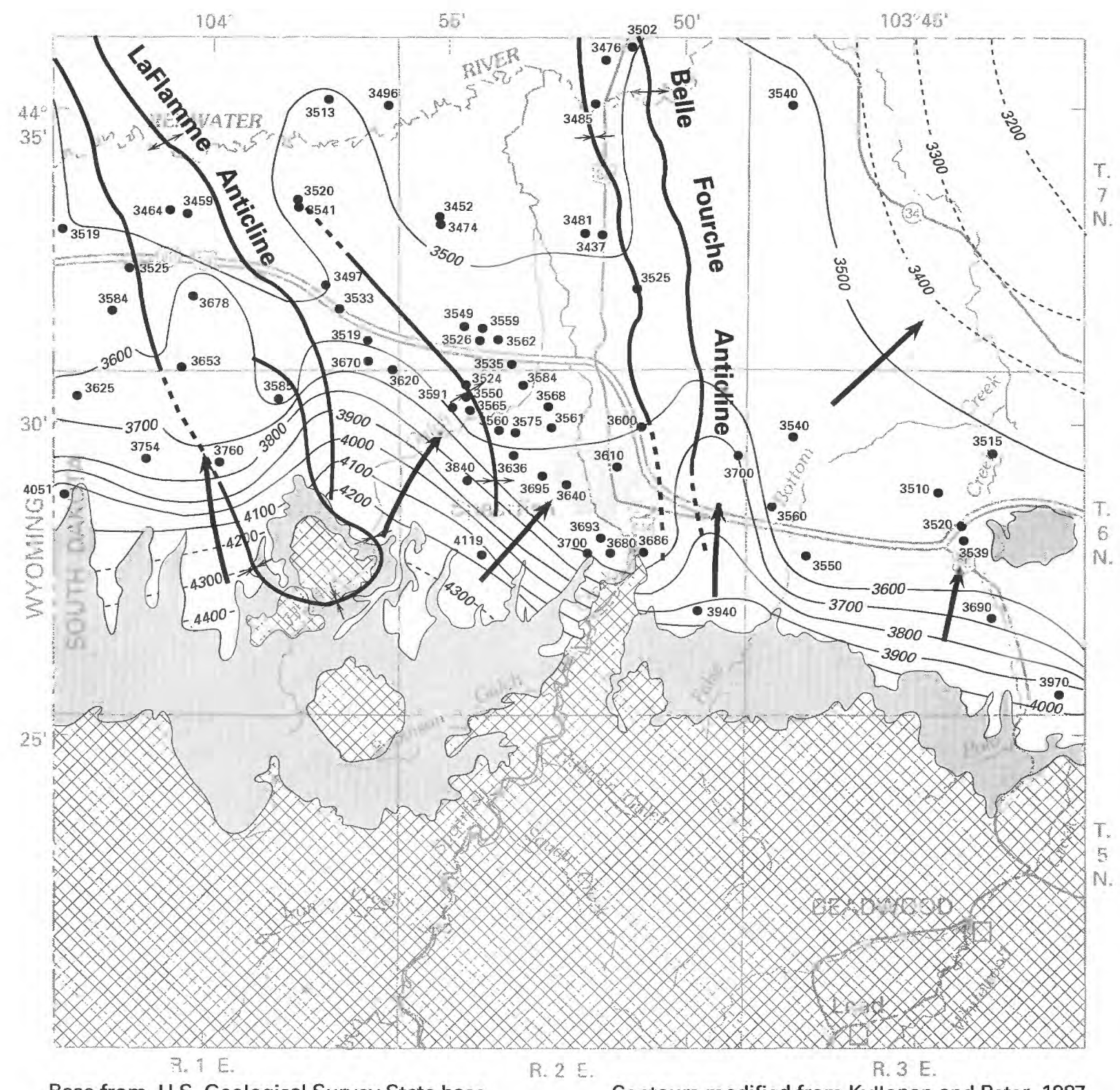

Base from U.S. Geological Survey State base map, 1:500,000. Drainage from Digital Line Graph, 1:100,000 and U.S. Geological Survey quadrangles, 1:24,000

\section{EXPLANATION}
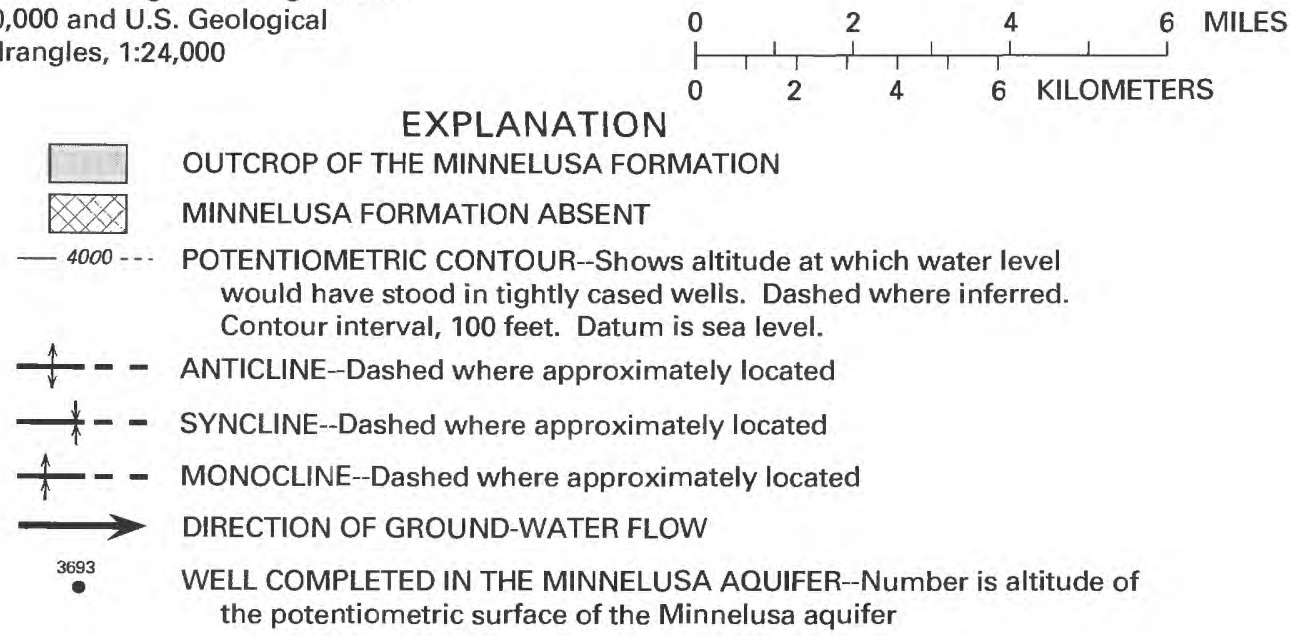

Figure 8. Potentiometric surface map of the Minnelusa aquifer, 1993. 
The Madison aquifer is highly heterogeneous. The local heterogeneity in the aquifer is due to fractures, joints, solution-enlarged openings, and a regional change in the character of the aquifer caused by a general thickening of the formation northward. Ground-water flow in the Madison aquifer may locally be controlled by large caverns (solutional openings) as illustrated by the caliper and acoustic-televiewer logs from the Ellingson well (fig. 9). In other areas of the formation, ground-water flow may be controlled by bedding-plane fractures and small vugs as shown by the caliper and acoustic-televiewer logs from the Kyte well (fig. 10).

Because the Madison Limestone is stratigraphically lower than the Minnelusa Formation, only about 20 wells have been completed in the aquifer within the study area. Most of these wells are water-supply wells drilled within the Spearfish city limits. Because of the lack of spatial data and the karstic nature of the surface of the Madison Limestone, a structure contour map for the top of the Madison Limestone was not constructed. Because there were very few water-level measurements from the Madison aquifer in 1993, the potentiometric surface is approximated for most of the study area (fig. 11). The general direction of ground-water flow is from south to north near the outcrop. Regionally, ground water moves north past Spearfish and then moves to the east. At the northern end of the study area, ground-water flow is from west to east (Downey, 1984; Kyllonen and Peter, 1987). The hydraulic gradient of the Madison aquifer is the steepest near the outcrop and decreases north of Spearfish. Near Spearfish, the bending of the potentiometric contours could be due to structural controls or the influence of city production wells.

\section{Stream/Aquifer Interaction}

A major source of recharge to the Minnelusa and Madison aquifers in the Spearfish area is from streams losing part or all of their flow as they cross the outcrops ("loss zones") of the Minnelusa Formation and Madison Limestone. Several streams (Spearfish Creek, False Bottom Creek, and Iron Creek) in the study area cross the outcrop of the Madison Limestone upgradient of the City of Spearfish (fig. 11) and may recharge the aquifers. Spearfish Creek, a perennial stream, has the largest discharge of any stream in the study area and therefore has the greatest potential for recharging the Minnelusa and Madison aquifers.

In 1910, the Homestake Mining Company constructed a 23,862-ft tunnel (aqueduct) that diverts water from Spearfish Creek upstream of the Madison Limestone loss zone. Spearfish Creek water is channeled through the aqueduct to a holding pond where the tunnel emerges about 1 mi south of Spearfish (fig. 4). From the holding pond, the water is diverted in a pipeline to standpipes, where it drops $665 \mathrm{ft}$ (Blackstone, 1914) to a hydroelectric power plant. After the water has been used to generate electricity for the Homestake Mining Company, it is discharged back to Spearfish Creek at Spearfish. The aqueduct has a width of $6.5 \mathrm{ft}$, and a side-wall height of $5 \mathrm{ft}$, with a 3.25 -ft-radius arched roof (Blackstone, 1914). The overall slope of the aqueduct is $1 \mathrm{in}$. per $100 \mathrm{ft}$. Concrete was used to line the floor and sides of the tunnel. The arched roof also was lined with concrete for about three-fifths of the distance (Blackstone, 1914).

A geologic cross section (fig. 12) was drawn along the strike of the aqueduct for sections A-A', $A^{\prime}-A^{\prime \prime}$, and $A^{\prime \prime}-A^{\prime \prime \prime}$ shown on figure 4. Cross section $A-A^{\prime}$ begins at the diversion of Spearfish Creek into the aqueduct. This section of the aqueduct is approximately $6,500 \mathrm{ft}$ in length and has a strike of $\mathrm{N} 35^{\circ} \mathrm{E}$. The elevation of the aqueduct is $4,375 \mathrm{ft}$ above mean sea level (Blackstone, 1914). This section passes through the Deadwood Formation, Winnipeg Formation, Englewood Limestone and enters the Madison Limestone at A'.

The second section $A^{\prime}-A^{\prime \prime}$ begins at a dogleg in the aqueduct. The strike of this section is $\mathrm{N} 5^{\circ} \mathrm{E}$ and extends for about 8,500 ft. This portion of the aqueduct passes through the Madison Limestone and the Minnelusa Formation. The third section A"-A"' has a strike of $\mathrm{N} 40^{\circ} \mathrm{E}$ and extends approximately $8,400 \mathrm{ft}$. This portion of the aqueduct passes through the Minnelusa Formation throughout its entire length. The aqueduct exits the ground at an elevation of $4,355 \mathrm{ft}$. The total distance that the aqueduct is in the Madison Limestone is approximately $6,300 \mathrm{ft}$, and the total distance in the Minnelusa Formation is about $10,400 \mathrm{ft}$. It is along these sections that water in the aqueduct could be recharging the Minnelusa and Madison aquifers. 


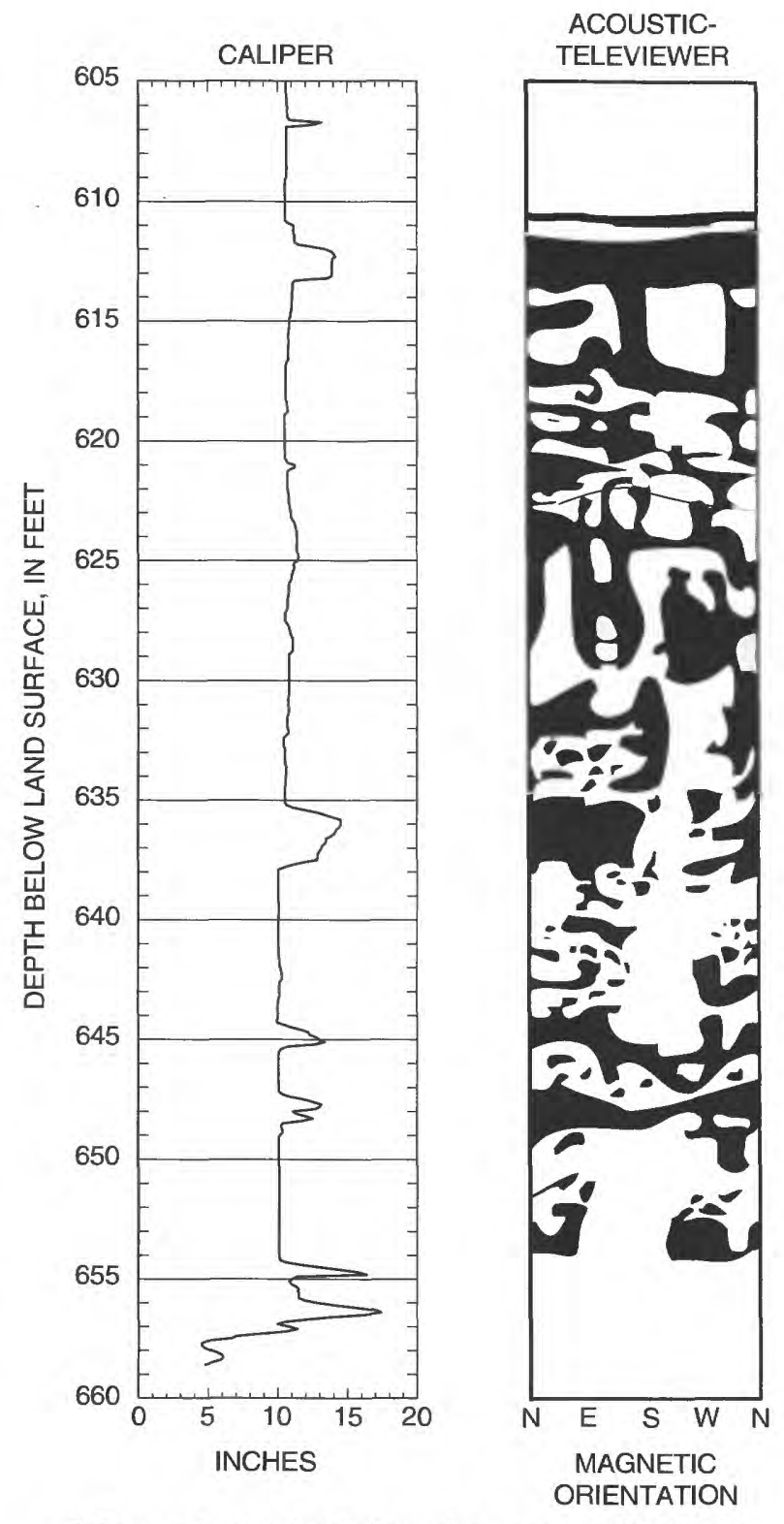

Caliper and acoustic-televiewer logs were provided by the U.S. Geological Research Project, Lakewood, Colorado.

Figure 9. Caliper and acoustic-televiewer logs for the upper part of the Madison aquifer in the Ellingson well. (Black areas of the acoustic-televiewer log represents the void space at the borehole wall.)

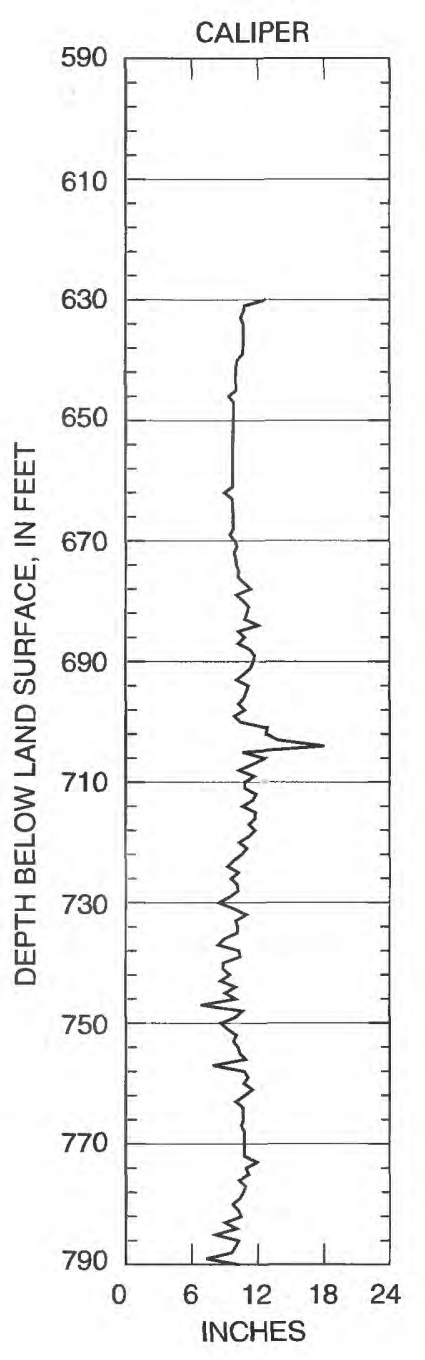

ACOUSTIC-

TELEVIEWER

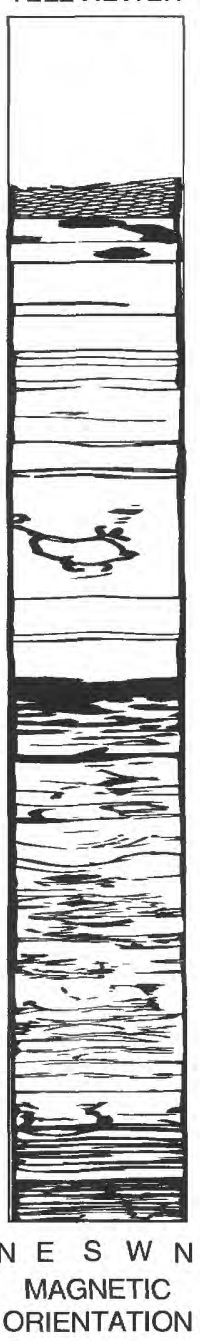

Caliper and acoustic-televiewer logs were provided by the U.S. Geological Research Project, Lakewood, Colorado.

Figure 10. Caliper and acoustic-televiewer logs for the upper part of the Madison aquifer in the Kyte well. (Black areas of the acoustic-televiewer log represents the void space at the borehole wall.) 


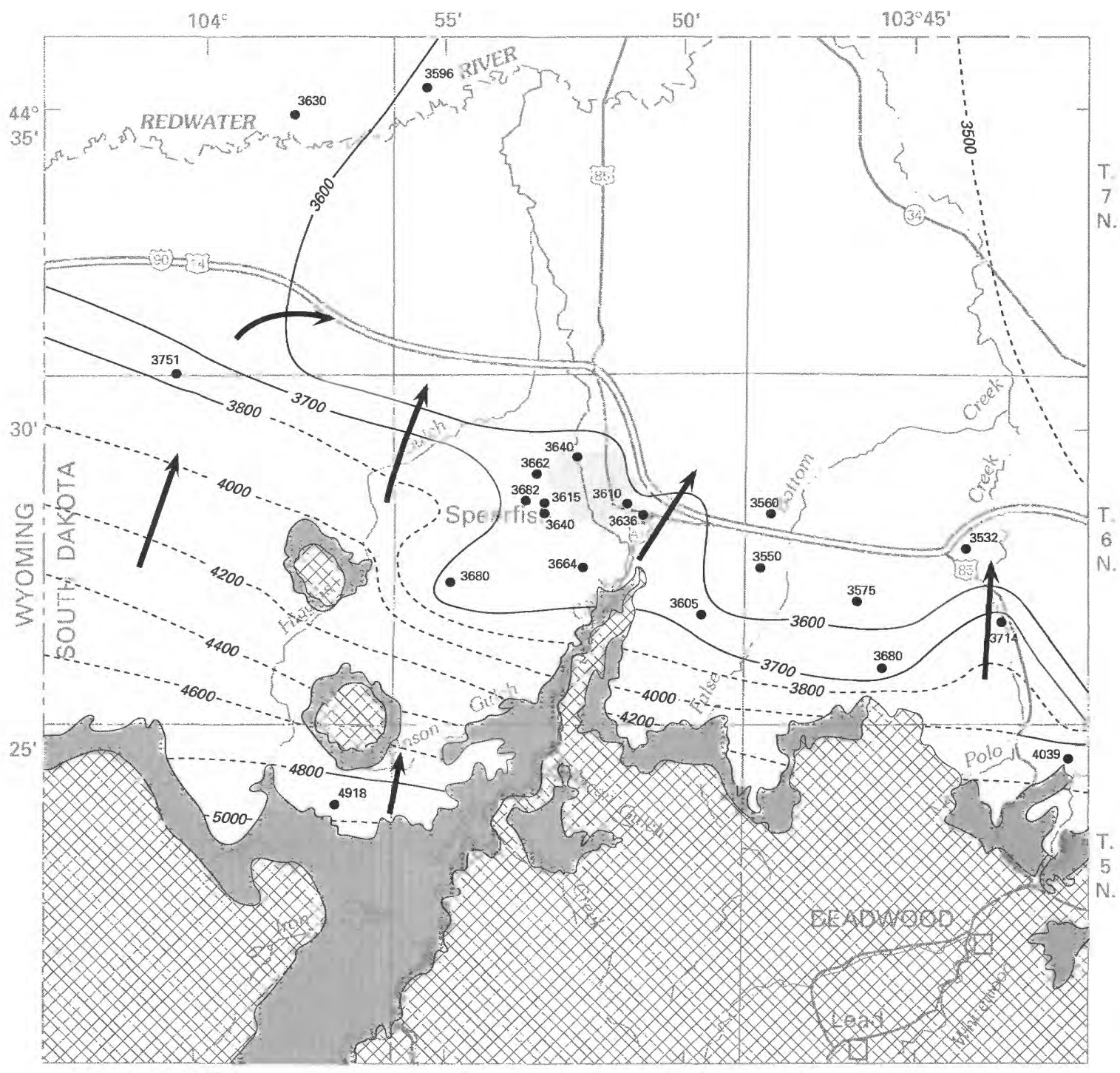

R. $1 \mathrm{E}$.

P. 2 E.

R. 3 E.

Base from U.S. Geological Survey State base map, 1:500,000. Drainage from Digital Line Graph, 1:100,000 and U.S. Geological Survey quadrangles, 1:24,000

Contours modified from Kyllonen and Peter, 1987

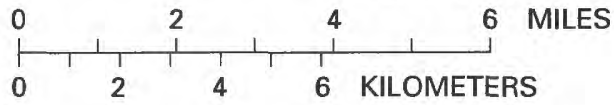

EXPLANATION

OUTCROP OF THE MADISON LIMESTONE
MADISON LIMESTONE ABSENT
POTENTIOMETRIC CONTOUR--Shows altitude at which
water level would have stood in tightly cased wells.
Dashed where inferred. Contour interval, variable.
Datum is sea level.
DIRECTION OF GROUND-WATER FLOW
WELL COMPLETED IN THE MADISON AQUIFER--Number
is altitude of the potentiometric surface of the Madison
aquifer

Figure 11. Potentiometric surface map of the Madison aquifer, 1993. 

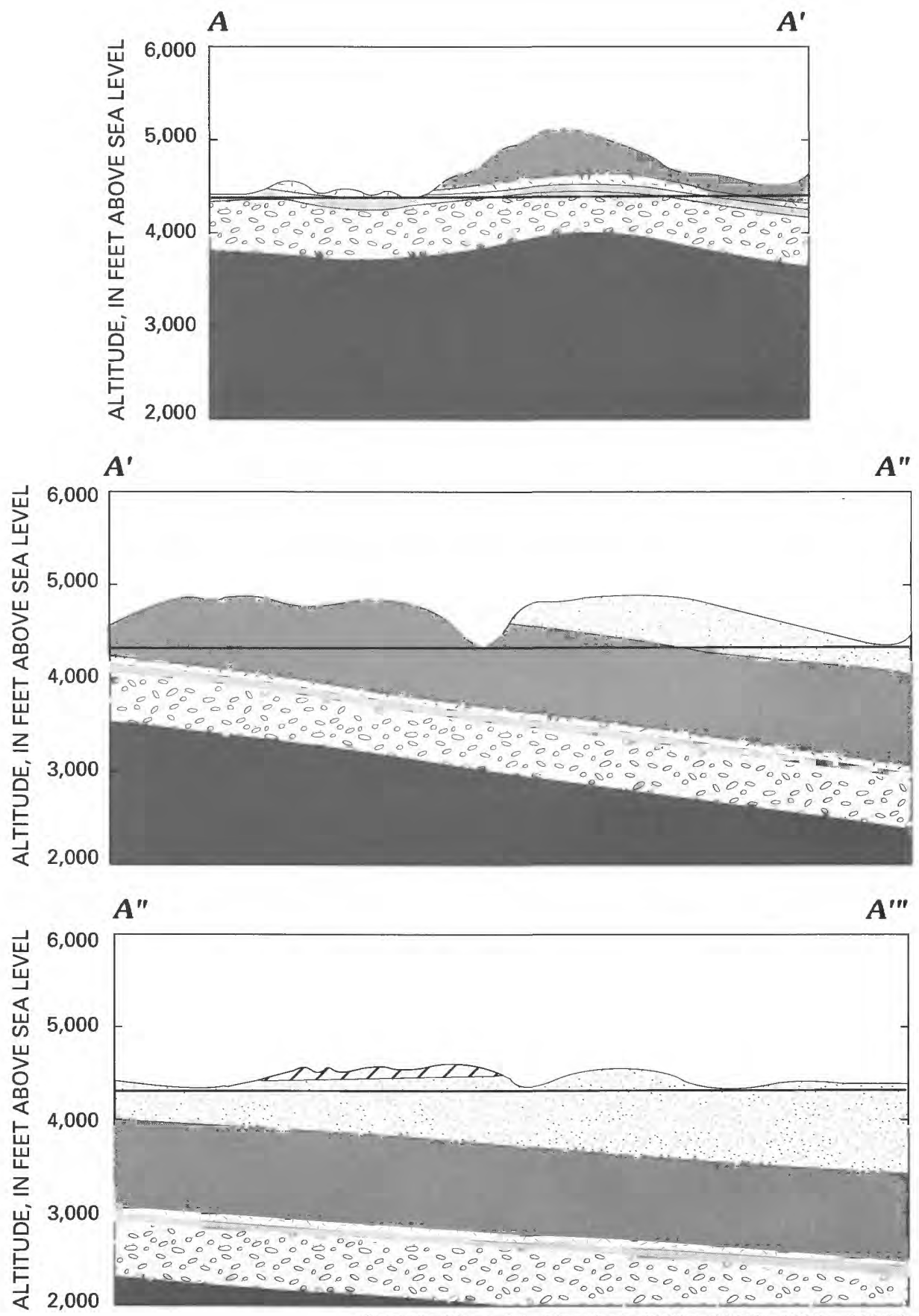

Compiled from A.L. Lisenbee, 1991a, 1991b, 1991c, 1991d, 1991e; and A.L. Lisenbee and J.A. Redden, 1991

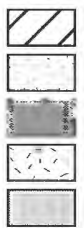
OPECHE FORMATION MINNELUSA FORMATION MADISON LIMESTONE ENGLEWOOD LIMESTONE WINNIPEG FORMATION

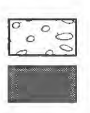
DEADWOOD FORMATION
PRECAMBRIAN (undivided) CONTACT
AQUEDUCT

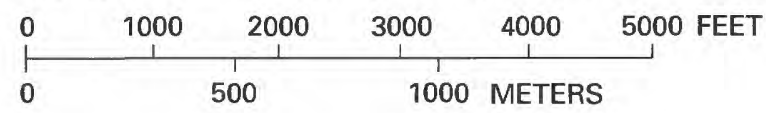

Figure 12. Geologic cross sections along aqueduct. (Locations of $A-A^{\prime}, A^{\prime}-A^{\prime \prime}$, and $A^{\prime \prime}-A^{\prime \prime \prime}$ are shown in figure 4.) 
The diversion of water through the aqueduct probably caused a decline in the potentiometric surface in the Minnelusa and Madison aquifers because of reduced recharge in the early 1900 's. Davis and others (1961) reported that an observation well completed in the Minnelusa aquifer located at 6N2E23BBBA had a water level about $15 \mathrm{ft}$ above land surface in 1907 . In 1956, the water level in this well had declined to about $74 \mathrm{ft}$ below land surface (fig. 13). From 1956 to the early 1980 's, the water level has fluctuated from about 36 to $84 \mathrm{ft}$ below land surface, but does not show a decreasing trend. Another observation well completed in the Minnelusa aquifer, LA-62A, located approximately 6 mi north of Spearfish (fig. 2), has shown seasonal fluctuations with no apparent long-term trend (fig. 13), indicating that the ground-water flow regime has established an appropriate equilibrium after the diversion of recharge from Spearfish Creek.

Streamflow records for the period of record from 1988-95 were analyzed at two streamflow-gaging stations along Spearfish Creek to quantify the recharge to the Minnelusa and/or Madison aquifers through the aqueduct. Figure 14a shows a comparison for 2 years of record. The first station is at an upstream location above the Madison Limestone loss zone (Spearfish Creek above Spearfish, 06430900), and the second station is at a downstream location, below the loss zone (Spearfish Creek at Spearfish, 06431500). Flow at the downstream gage usually is less than the upstream gage (fig. 14b), which indicates there is a water loss into the formations between the two sites. At certain times though, more flow is measured at the downstream gage than in the upstream one, which may indicate that water is moving from the aquifer and recharging Spearfish Creek or that precipitation is occurring in the lower part of the basin and is not measured at the upstream site.

The flow at the downstream gage was subtracted from the flow at the upstream gage to estimate the daily net loss into the formations between the two sites. Table 1 presents the average daily net loss, by water year from 1989-94, from Spearfish Creek between the two sites. The average loss in millions of gallons of water per day for Spearfish Creek ranged from a high of $4.1 \mathrm{Mgal} / \mathrm{d}$ in water year 1993 to a low of $0.4 \mathrm{Mgal} / \mathrm{d}$ in water year 1992.
Table 1. Daily net losses of water along Spearfish Creek into the Minnelusa Formation and Madison Limestone between the upstream and downstream gaging sites

\begin{tabular}{ccc}
\hline $\begin{array}{c}\text { Water } \\
\text { year }\end{array}$ & $\begin{array}{c}\text { Average } \\
\text { daily loss } \\
\text { (cubic feet } \\
\text { per second) }\end{array}$ & $\begin{array}{c}\text { Average } \\
\text { daily loss } \\
\text { (million gallons } \\
\text { per day) }\end{array}$ \\
\hline 1989 & 2.5 & 1.6 \\
1990 & 1.9 & 1.2 \\
1991 & 3.6 & 2.3 \\
1992 & .6 & .4 \\
1993 & 6.3 & 4.1 \\
1994 & 4.5 & 2.9 \\
\hline
\end{tabular}

\section{Temporal Water-Level Fluctuations}

In the Spearfish area, water levels in the Minnelusa and Madison aquifers are monitored continuously in observation wells maintained by the State of South Dakota. The observation wells within the study area consist of five wells completed in the Minnelusa aquifer and two wells completed in the Madison aquifer (fig. 2, designated by the first two letters LA). A summary of the water-level data from these wells is published biannually by the USGS (Driscoll and Bradford, 1994; Driscoll and others, 1996). Fluctuations in water levels measured at observation wells in the study area probably are the direct result of recharge to the aquifer and from water withdrawals due to pumping.

Water levels are compared in figure 15 for observation wells LA-88B (Minnelusa aquifer) and LA-88C (Madison aquifer), which were selected because they show a common relation in hydraulic head between the Minnelusa aquifer and Madison aquifer for the study area. The wells are located within $15 \mathrm{ft}$ of each other within the city limits of Spearfish (fig. 2). The hydrograph shows that the hydraulic head in the Minnelusa aquifer generally is 10 to $20 \mathrm{ft}$ higher than the hydraulic head in the Madison aquifer at this location. Both aquifers show a cyclic pattern, with abrupt water-level rises in May through June corresponding to snowmelt runoff and increased spring precipitation. The effects of recharge during spring are more pronounced in the Madison aquifer than in the Minnelusa aquifer. 

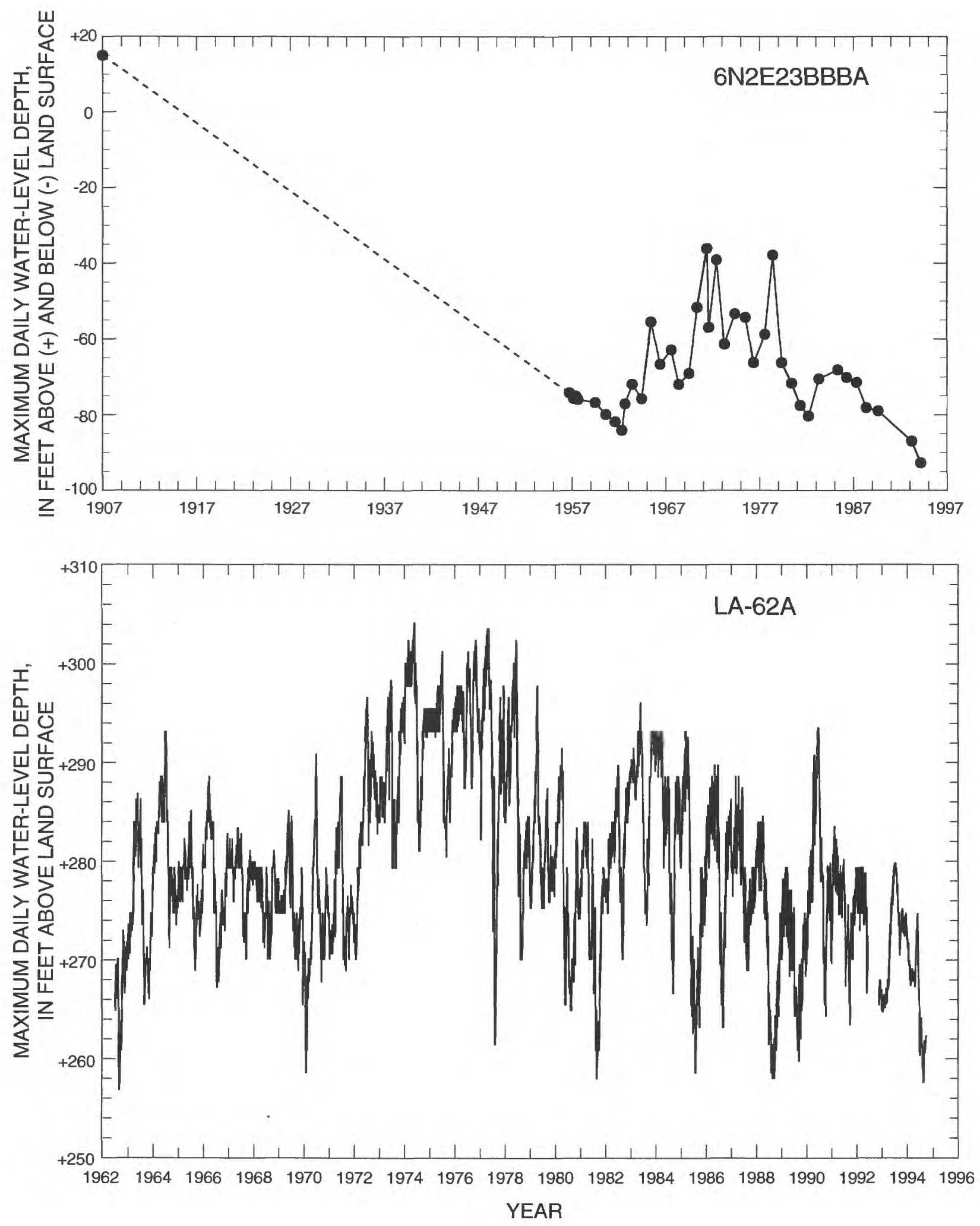

Figure 13. Long-term hydrographs for two wells completed in the Minnelusa aquifer. 

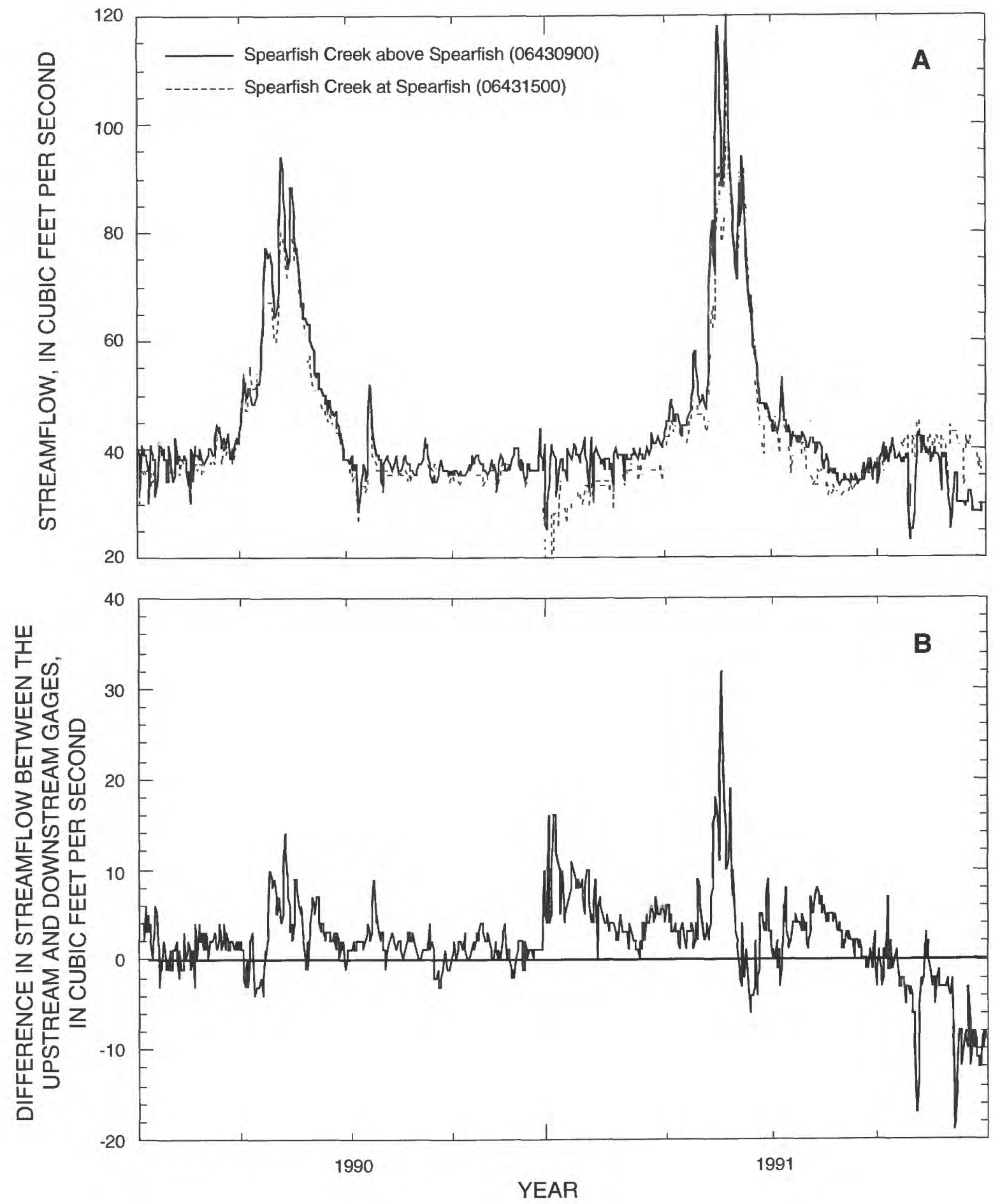

Figure 14. Comparison of streamflow in Spearfish Creek above the Madison Limestone outcrop (06430900) and below (06431500) for 2 years of record. 


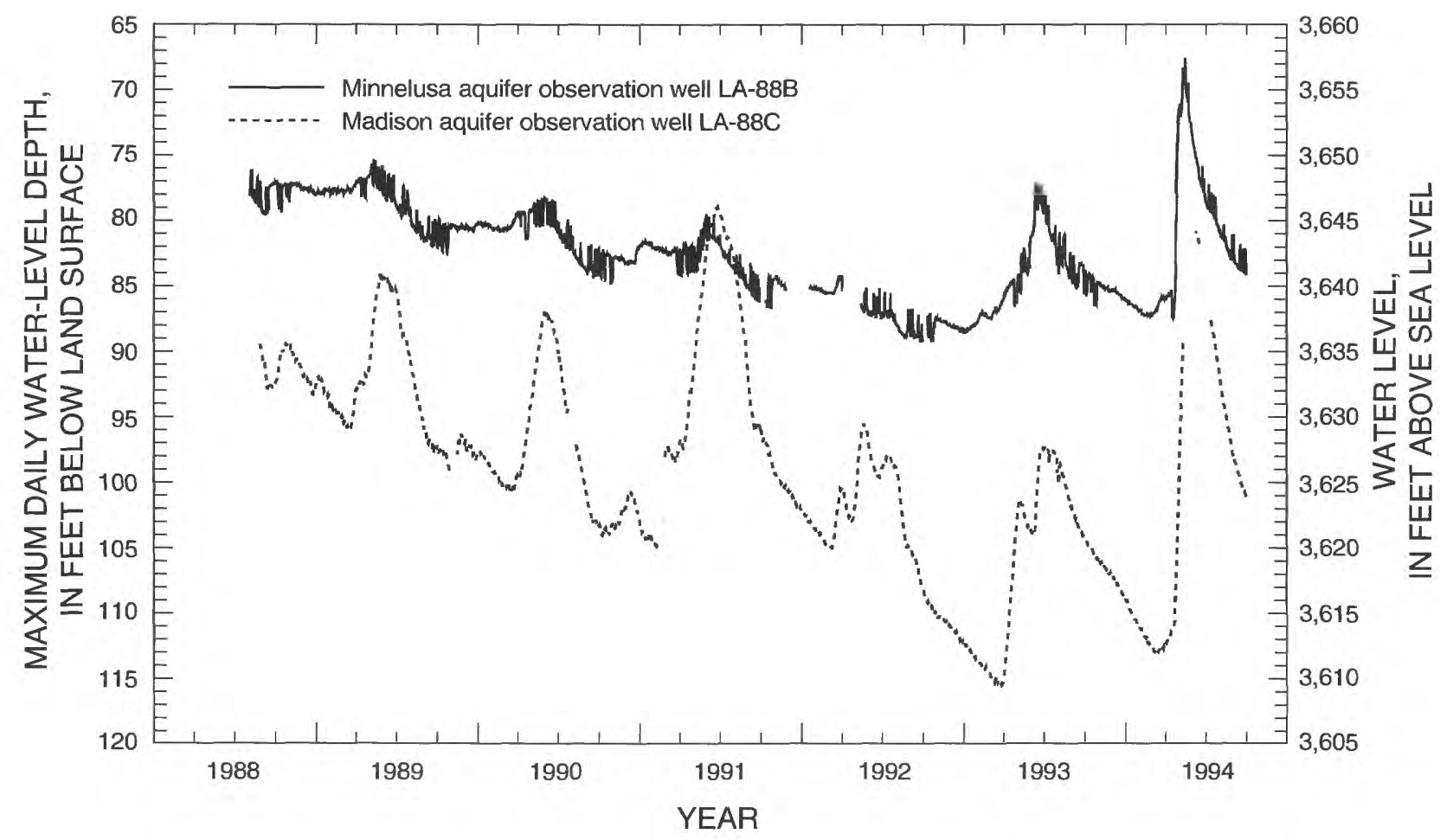

Figure 15. Hydrographs for observation wells LA-88B and LA-88C.

The hydraulic head in both aquifers generally declined between 1988 and the beginning of 1993. The lowest water level recorded was in September and October 1992 for the Minnelusa aquifer and in March 1993 for the Madison aquifer. The water levels began rising in the spring of 1993 because of above-normal precipitation and streamflow loss (table 1). The highest water level recorded was in May 1994 for the Minnelusa aquifer and in June 1991 for the Madison aquifer. Changes in hydraulic head in the Madison aquifer observed at LA-88C show a strong relation to streamflow measured at station 06430900 on Spearfish Creek (fig. 2, fig. 16). The peak water levels in the well correspond to peak streamflow; however, the peak water levels in the well lag the streamflow by about 30 days (fig. 16).

\section{HYDRAULIC PROPERTIES FROM AQUIFER TESTING}

To estimate rates of ground-water movement, hydraulic properties such as transmissivity and storativity need to be quantified. Transmissivity $(T)$ represents the ease of fluid movement through a saturated subsurface unit, and storativity $(S)$ represents the capacity of the formation to store and release water due to changes in the hydraulic head. These properties can be determined from laboratory analysis, in-situ hydraulic testing, and/or regional water-budget calculations. Because the location and occurrence of fractures and dissolution features are important in characterizing ground-water flow in the Minnelusa and Madison aquifers, laboratory analysis of rock cores would not adequately characterize the transmissivity and storativity of the formations on a scale needed for groundwater resource evaluation. Thus, this investigation focused on in-situ testing (also referred to as aquifer testing) and water-budget calculations to identify the hydraulic properties needed to quantify ground-water movement. In this section, the results of aquifer testing in the Minnelusa and Madison aquifers are discussed. In a subsequent section, estimates of transmissivity are made based on regional water-budget calculations using numerical models of ground-water flow in the Minnelusa and Madison aquifers. 


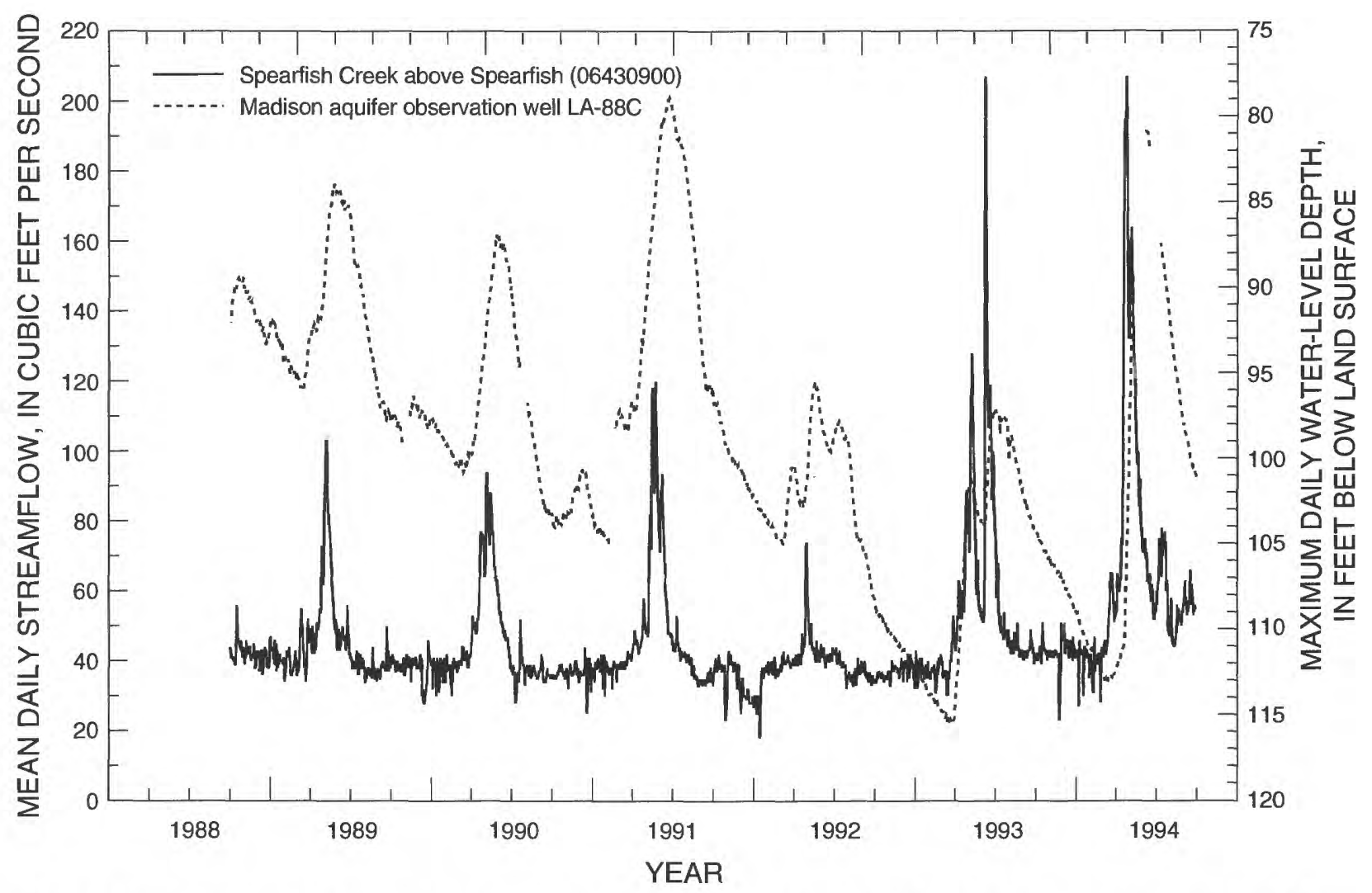

Figure 16. Comparison of streamflow and aquifer hydrographs for Spearfish Creek and observation well LA-88C.

\section{Methods}

Aquifer testing relies on interpreting changes in the hydraulic head at various points in the formation due to planned perturbations in the ground-water flow regime-for example, planned withdrawals from one or more wells. The Minnelusa and Madison aquifers are fractured and dissolution enhanced, and are subject to various structural features that may affect the ground-water movement. Thus, the hydraulic properties (transmissivity and storativity) of the formations probably vary over the extent of the study area. However, the lack of and distance between observation wells in Minnelusa and Madison aquifers make it difficult to interpret heterogeneity in hydraulic properties based on aquifer testing. Consequently, for the purpose of designing and interpreting aquifer tests in the Minnelusa and Madison aquifers, the formations are conceptualized as homogeneous and isotropic in the vicinity of the wells that are monitored. Furthermore, the network of fractures and solutional openings are assumed to behave as a porous continuum. Although these formations are recognized as being hetero- geneous, the interpretation of aquifer tests using the assumption of homogeneity may provide order-ofmagnitude estimates of hydraulic properties and generally indicate areas of high permeability or low permeability in the Minnelusa and Madison aquifers. The assumption that networks of fractures and solutional openings behave as a porous continuum is a common assumption in many ground-water investigations of fractured rock.

Several types of aquifer tests were conducted during 1992 and 1993 to determine the transmissivity and storativity of the Minnelusa and Madison aquifers. Tests were conducted that hydraulically stressed different volumes of the formation. In the Minnelusa aquifer, an interference test was conducted at the golf course site (fig. 17), where drawdown was measured $1,200 \mathrm{ft}$ from the pumped well. In addition, airpressurized slug tests were conducted in observation wells LA-88A, LA-88B (fig. 17) and LA-87B (fig. 2). The air-pressurized slug tests, however, hydraulically stressed the formation only in the immediate vicinity (a few feet to tens of feet) around these wells. 


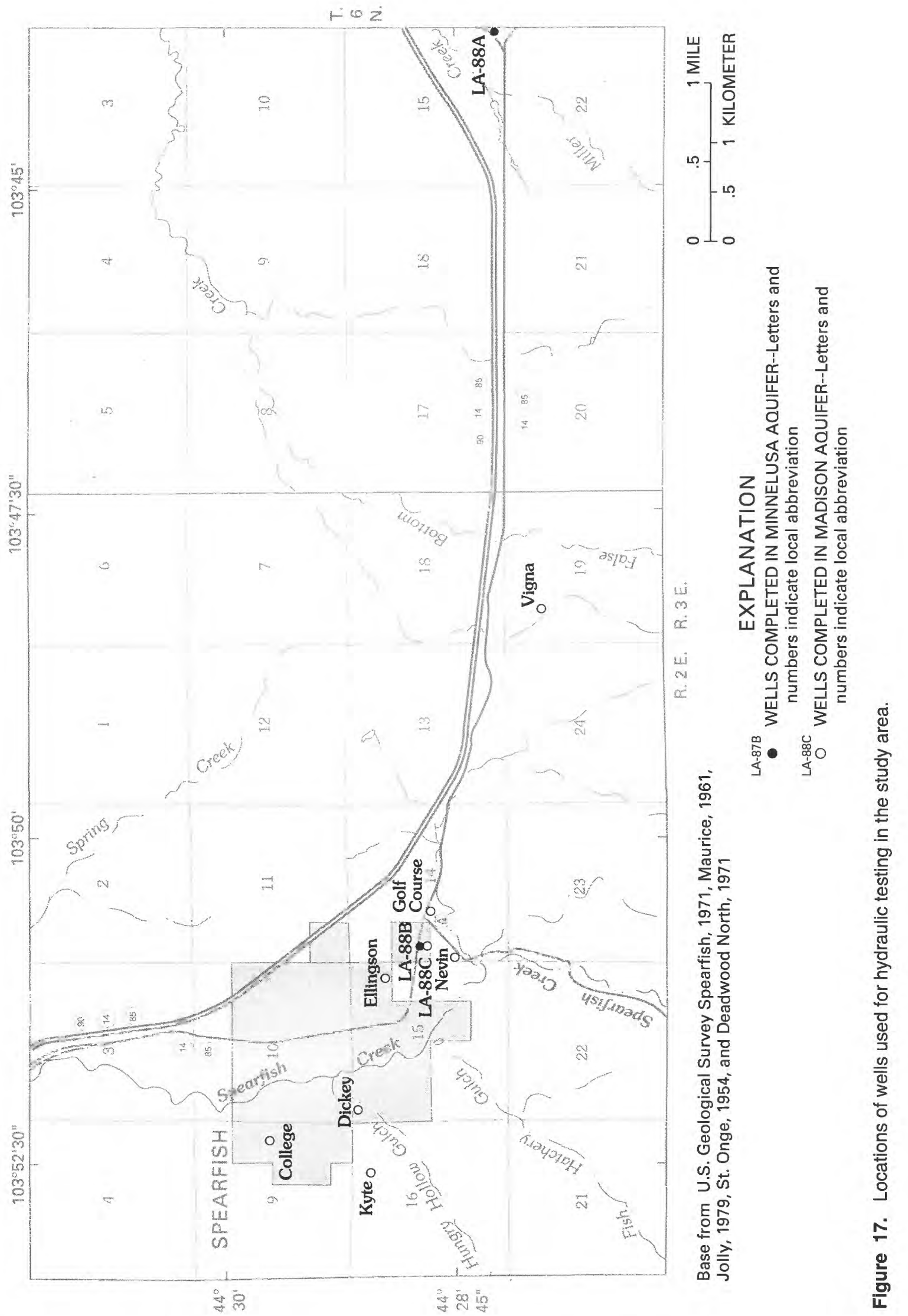


In the Madison aquifer, an interference test was conducted in the Dickey well and drawdown was measured in the Kyte well, 1,800 ft from the pumped well (fig. 17). In addition, specific-capacity tests were conducted in the College, Dickey, Ellingson, and Nevin wells (fig. 17). Drawdown was not detected in any observation wells during pumping for the specificcapacity tests in the College, Ellingson, or Nevin wells. In the Nevin well, a step-drawdown test was conducted to estimate the turbulent head loss coefficient. Additionally, an air-pressurized slug test was conducted in the Madison observation well LA-88C (fig. 17).

During the aquifer tests, data were collected according to standards for aquifer-test data collection and analysis (Stallman, 1971). Production-well pumping rates were maintained within 10 percent of the design pumping rate, water levels in the nonflowing observation wells were measured to $0.01 \mathrm{ft}$, shut-in pressures in flowing observation wells were measured to $0.1 \mathrm{lb} / \mathrm{in}^{2}$ or less depending on the scale of the pressure gage used, and altitudes of the measuring points were measured to $0.1 \mathrm{ft}$. Distances between wells were measured from topographic maps with a scale of 1:24,000.

Because drawdown data collected from an aquifer test must be corrected for external influences, such as water-level trends and barometric pressure, weekly water-level data were collected in city production wells to establish pre- and post-aquifer test waterlevel trends in the Minnelusa and Madison aquifers. In selected observation wells, daily water levels were measured to establish the relation between water-level fluctuations and barometric pressure changes. Drawdown data collected during the long-term aquifer tests were corrected for water-level trends due to recharge and barometric pressure changes.

A recording barograph was used so that corrections could be made for water-level fluctuations in the observation wells due to atmospheric (barometric) pressure changes during the aquifer tests. A decrease in barometric pressure causes a water-level rise, and an increase in barometric pressure causes a water-level decline. Without applying this correction to aquifertest data, an erroneous interpretation of the data would result. The response of water levels in the Minnelusa and Madison aquifers to barometric pressure changes was established prior to aquifer testing by recording barometric pressure and the corresponding water levels. From the known relation between change in barometric pressure and change in water level, the corrected drawdown during the aquifer test was determined (Ferris and others, 1962; Kruseman and de Ridder, 1991).

\section{Minnelusa Aquifer}

One interference test was conducted using a private production well completed in the Minnelusa aquifer. In addition, air-pressurized slug tests were conducted at three observation wells completed in the Minnelusa aquifer.

\section{Interference Test}

A 42-hour interference test was conducted at the golf course well (fig. 17) to estimate transmissivity and storativity in the Minnelusa aquifer and to investigate the hydraulic connection of the Minnelusa and Madison aquifers in the Spearfish area. The pumping rate in the production well was maintained at a ccnstant $220 \mathrm{gal} / \mathrm{min}$ for the duration of the test. Drawdown measurements were made during pumping, and during recovery after the pump was shut off. During the recovery period, data were collected until the water levels in the production well and observation well were at pre-test levels. Only observation well, LA-8\&B (fig. 17), which is completed in the Minnelusa aquifer, responded to pumping in the golf course well; other observation wells in the Minnelusa and Madison aquifers had no measurable drawdown. The radial distance from LA-88B to the golf course well is $1,270 \mathrm{ft}$. The drawdown data from this aquifer test is in table 6 in the Supplemental Information section at the end of the report.

Transmissivity $(T)$ and storativity $(S)$ of the area of the Minnelusa aquifer around the golf course well were estimated from drawdown data using the analytical method given by Theis (1935). This method is based on the assumptions that the aquifer is iso'ropic, homogeneous, areally extensive, and fully confined. The drawdown data are superimposed on the Tr ais type curve in figure 18. Matching of the two curves yields a transmissivity estimate of $9,600 \mathrm{ft}^{2} / \mathrm{d}$ and a storativity estimate of $7.4 \times 10^{-5}$. The transmissivity and storativity estimated from this test are represent $z$ tive of the hydraulic properties over the scale approximately equal to the distance from the pumped well to the observation well $(1,200 \mathrm{ft})$. 


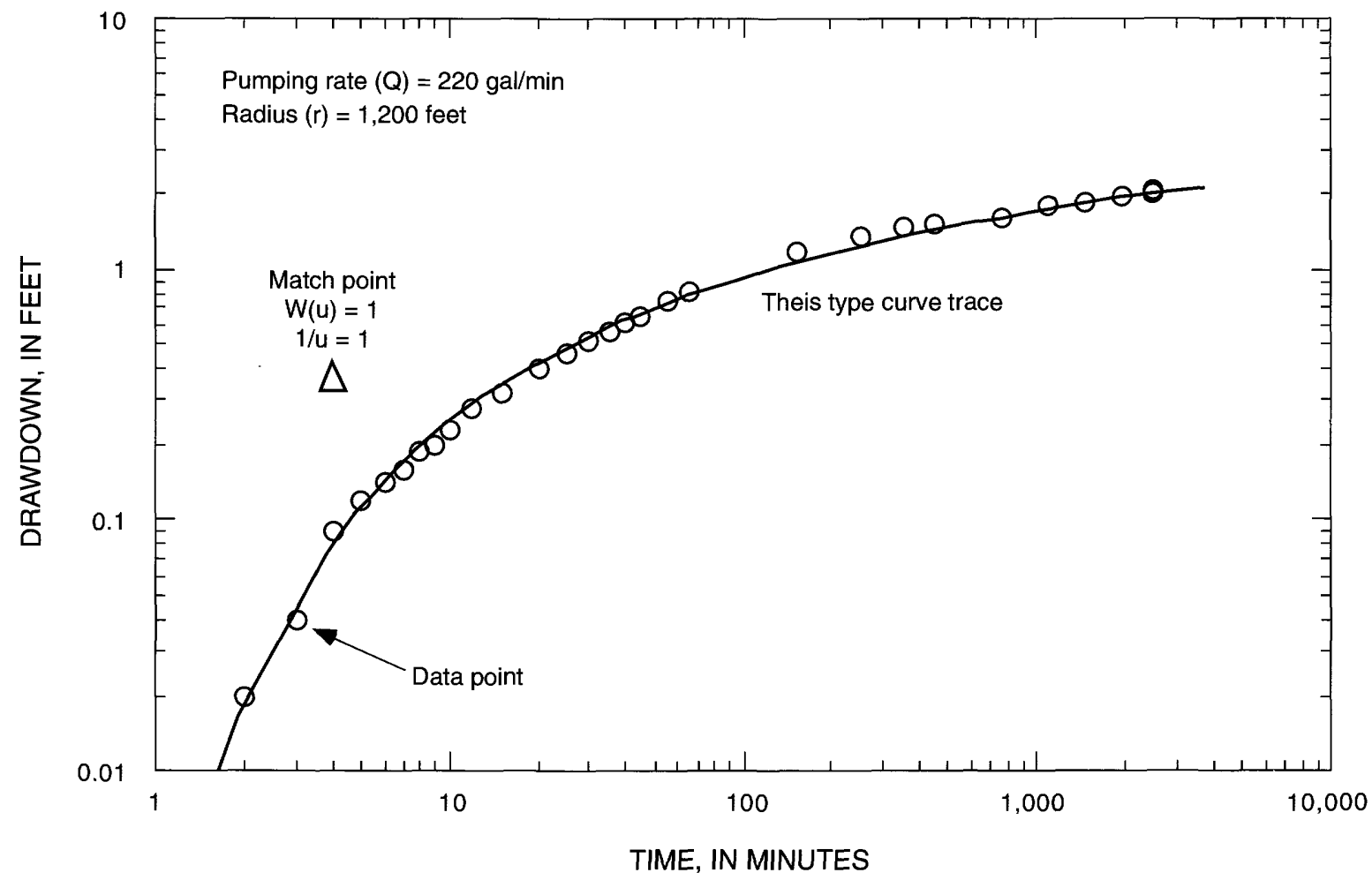

Figure 18. Best fit type curve match to the drawdown data for observation well LA-88B from pumping the golf course well.

\section{Air-Pressurized Slug Tests}

Air-pressurized slug tests were conducted in the Minnelusa aquifer at observation wells LA-87B (fig. 2), LA-88A, and LA-88B (fig. 17). These tests hydraulically stress only a limited volume of geologic material surrounding the well, within a few feet to tens of feet in radius from the well. The tests were conducted to estimate transmissivity and storativity in the vicinity of the observation wells. The results also provided a comparison with the hydraulic properties determined from the interference test, which affected a radius of $1,200 \mathrm{ft}$ within the aquifer.

The method used to conduct and interpret the airpressurized slug tests in this report are presented in Greene and Shapiro (1995) and Shapiro and Greene (1995). Air-pressurized slug tests are conducted by pressurizing the air in the casing above the column of water in the well, monitoring the declining water level, and then instantly releasing the air pressure and monitoring the rising water level until the original static level is achieved. The recovery data are analyzed graphically using a family of type curves developed by Shapiro and Greene (1995) to determine transmissivity and storativity.
One air-pressurized slug test was conducted in observation well LA-87B using $6.5 \mathrm{lb} / \mathrm{in}^{2}$ to depress the water level in the well casing until a new equilibrium water level was achieved. The data plot and matching type curve for this test are shown in figure 19; the data are presented in table 7 in the Supplemertal Information section. The estimates of $T\left(15 \mathrm{ft}^{2} / \mathrm{d}\right)$ and $S$ $\left(1.0 \times 10^{-1}\right)$ from this test are presented in table 2 .

Three air-pressurized slug tests were conducted in observation well LA-88B where different applied air pressures $\left(30,12\right.$, and $\left.5 \mathrm{lb} / \mathrm{in}^{2}\right)$ were used to depress the water level to a new equilibrium. Varying the applied pressure affects the radius of investigation around the slugged well. Field-data and matching type curves for these tests are shown in figure 20. Poor fits for earlytime and late-time data were obtained for all three pressures. Estimates of $T$ and $S$ were made ty fitting the type curves to the middle part of the data. Results for these tests are shown in table 2, and the data are presented in table 8 in the Supplemental Information section. The estimates of $T$ range from $19 \mathrm{f}^{2} / \mathrm{d}$ from the test where $30 \mathrm{lb} / \mathrm{in}^{2}$ was applied to $42 \mathrm{ft}^{2} / \mathrm{d}$ from the test where $5 \mathrm{lb} / \mathrm{in}^{2}$ was applied. All three tests gave similar results of $1.0 \times 10^{-9}$ for storativity. 


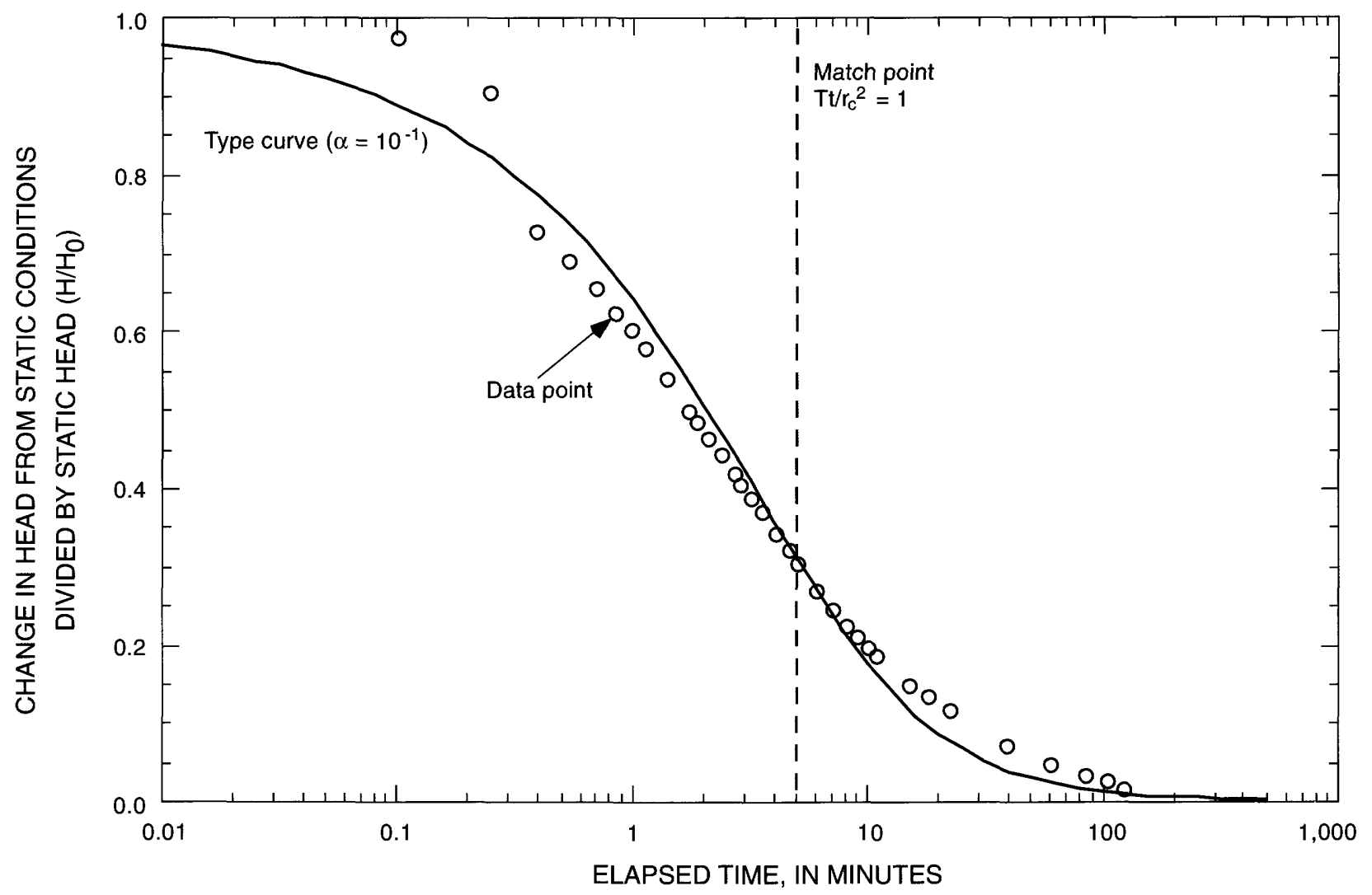

Figure 19. Best fit type curve match to the drawdown data from the air-pressurized slug test conducted in observation well LA-87B using an applied air pressure of 6.5 pounds per square inch.

Table 2. Transmissivity $(T)$ and storativity $(S)$ estimates from type-curve matches to recovery data collected during air-pressurized slug tests conducted in observation wells LA-88A, LA-88B, and LA-87B near Spearfish, S. Dak.

[Radius of casing $\left(r_{C}\right)=0.21 \mathrm{ft}$ : radius of open interval $\left(r_{s}\right)=0.20 \mathrm{ft}$ : aquifer transmissivity $(T)$ and storativity $(S)$ is equal to the test interval value times the aquifer thickness $(B=200 \mathrm{ft})$ divided by the test interval thickness $(b) ; \Delta \mathrm{r} / \Delta=$ ratio of the change in water level at end of the pressurized portion of the slug test to the maximum change in water level for the prescribed constant air pressure applied to the well $\left.\alpha=S r_{s} / r_{c}{ }^{2}\right]$

\begin{tabular}{lclllcccccc}
\hline Well & $\begin{array}{c}\text { Applied } \\
\text { pressure } \\
\text { (pounds } \\
\text { per square } \\
\text { inch) }\end{array}$ & $\Delta \mathbf{r} / \Delta$ & $\begin{array}{c}\text { Match point, } \boldsymbol{t} \\
\text { (minutes) }\end{array}$ & $\alpha$ & $\begin{array}{c}\text { Thickness } \\
\text { of test } \\
\text { interval } \\
\text { (feet) }\end{array}$ & $\begin{array}{c}\text { Transmissivity } \\
\text { of test } \\
\text { interval } \\
\text { (feet squared } \\
\text { per day) }\end{array}$ & $\begin{array}{c}\text { Storativity } \\
\text { of test } \\
\text { interval } \\
\text { (dimension- } \\
\text { less) }\end{array}$ & $\begin{array}{c}\text { Aquifer } \\
\text { trans- } \\
\text { missivity } \\
\text { (feet } \\
\text { squared } \\
\text { per day) }\end{array}$ & $\begin{array}{c}\text { Acrsifer } \\
\text { storativity } \\
\text { (dim?nsion- } \\
\text { less) }\end{array}$ \\
\hline LA-87B & 6.5 & 1.0 & 5 & $10^{-1}$ & 24 & 13 & $1 \times 10^{-1}$ & 125 & 1 \\
LA-88B & 5 & 1.0 & 1.5 & $10^{-9}$ & 33 & 42 & $1 \times 10^{-9}$ & 254 & $6 \times 10^{-9}$ \\
-- & 12 & 1.0 & 2 & $10^{-9}$ & 33 & 31 & $1 \times 10^{-9}$ & 187 & $6 \times 10^{-9}$ \\
-- & 30 & 1.0 & 3.25 & $10^{-9}$ & 33 & 19 & $1 \times 10^{-9}$ & 115 & $6 \times 10^{-9}$ \\
LA-88A & 5 & 1.0 & .7 & $10^{-9}$ & 47 & 90 & $1 \times 10^{-9}$ & 382 & $4 \times 10^{-9}$ \\
-- & 5 & .61 & .65 & $10^{-9}$ & 47 & 100 & $1 \times 10^{-9}$ & 425 & $4 \times 10^{-9}$ \\
-- & 5 & .43 & .7 & $10^{-9}$ & 47 & 90 & $1 \times 10^{-9}$ & 382 & $4 \times 10^{-9}$ \\
\hline
\end{tabular}




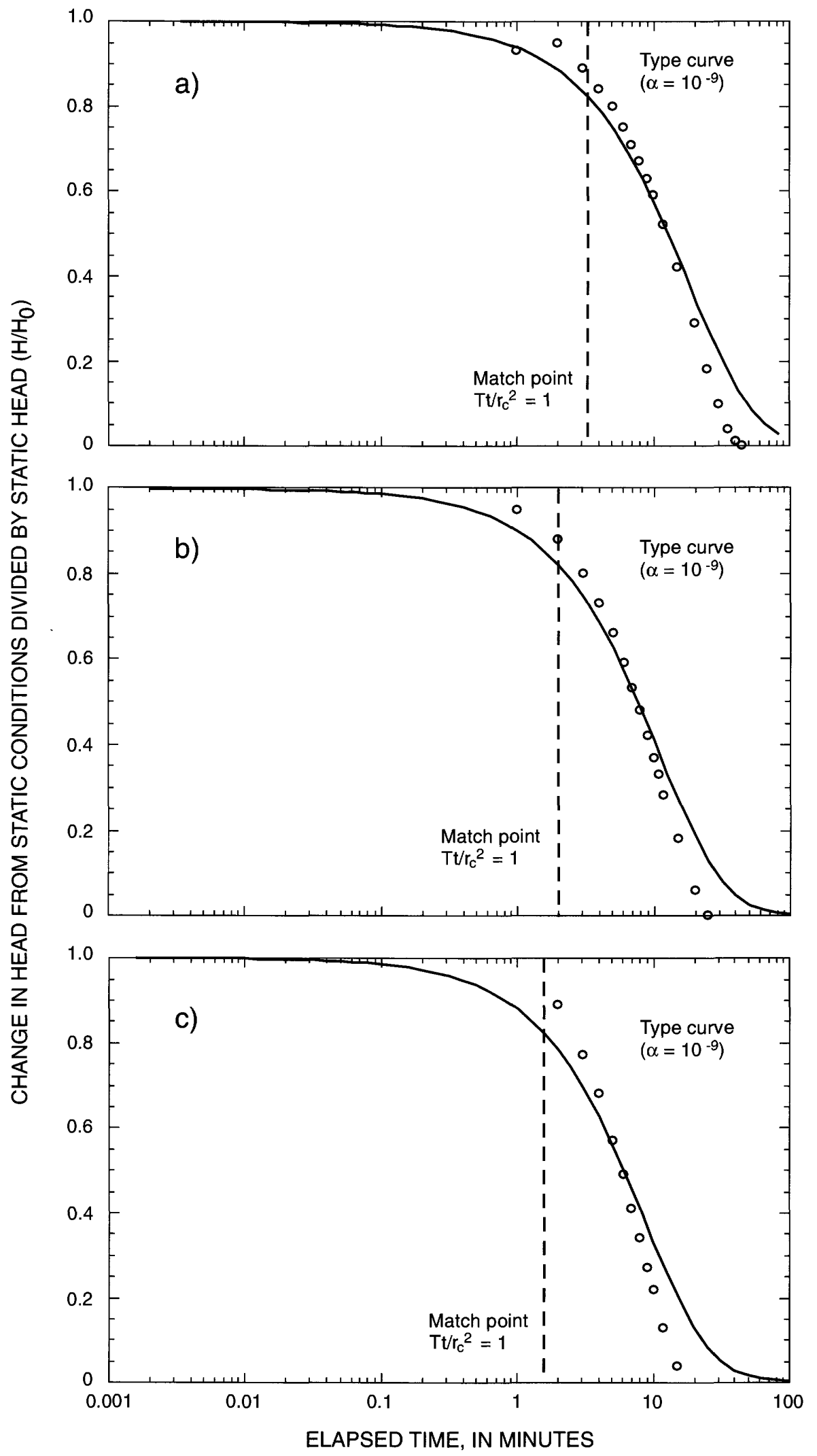

Figure 20. Best fit type curve match to the drawdown data from the air-pressurized slug tests conducted in observation well LA-88B using an applied air pressure of a) 30 , b) 12, and c) 5 pounds per square inch. 
Three air-pressurized slug tests also were conducted in observation well LA-88A. In each of these tests the applied air pressure was held constant at $5 \mathrm{lb} / \mathrm{in}^{2}$; however, the pressurized part of the tests was terminated before an equilibrium water level was achieved. The methods described by Shapiro and Greene (1995) were used to determine $T$ and $S$ from these three tests. Field data and matching type curves for these tests are shown in figure 21. All three tests gave similar results (table 2 ) for transmissivity (approximately $90 \mathrm{ft}^{2} / \mathrm{d}$ ) and storativity $\left(1.0 \times 10^{-9}\right)$ for the test interval. The data from these tests are presented in table 9 in the Supplement Information section.

Observations wells LA-87B, LA-88A, and LA-88B only partially penetrate the Minnelusa aquifer. Therefore, the estimates of $T$ and $S$ from the airpressurized slug tests conducted in these wells are representative of the length of the formation that is penetrated. For the purpose of comparison, however, estimates of $T$ and $S$ from these tests are extrapolated to consider the entire thickness of the Minnelusa aquifer. This is done by multiplying the estimates of $T$ and $S$ from the air-pressurized slug test by $(B / b)$, where $B$ is the thickness of the formation (assumed to be $200 \mathrm{ft}$ ) and $b$ is the length of the observation well that is open to the Minnelusa aquifer (thickness of test interval). The results of extrapolating the estimates of $T$ and $S$ from slug tests in the Minnelusa aquifer to consider the thickness of the formation also are presented in table 2 .

\section{Madison Aquifer}

One interference test and four specific-capacity tests were conducted using City production wells completed in the Madison aquifer. In addition, airpressurized slug tests were conducted at an observation well completed in the Madison aquifer.

\section{Interference Test}

A 6-day interference test was conducted at the Dickey well (fig. 17) to estimate transmissivity and storativity in the Madison aquifer. The pumping rate in the production well (Dickey well) was maintained at a constant rate of $680 \mathrm{gal} / \mathrm{min}$ for the duration of the test. Only one well completed in the Madison aquifer, the Kyte well, responded to pumping of the Dickey well. The radial distance from the Dickey well to the Kyte well is $1,800 \mathrm{ft}$. In addition, no drawdown was measured in observation wells completed in the Minnelusa aquifer.
Drawdown measurements were obtained in the Dickey and Kyte wells for the duration of the pumping and during the recovery period until the water levels in both the wells were at pre-test levels. The aquifer test data are presented in table 10 in the Supplemental Information section.

The flattening of the drawdown curve at the Kyte well (fig. 22) between 100 and 600 minutes of elapsed time is indicative of formations having families of fractures with different hydraulic characteristics (Streltsova, 1988). For example, in the Madison aquifer, large solutional openings act as the init:al source of water being pumped. These solutional openings intersect a more diffuse set of fractures in the formation. As pumping continues, the fluid pressure in the large solutional openings is reduced, resulting in hydraulic gradients which allow water in the network of diffuse fractures to feed the large solutional openings. A schematic of a formation having a network of solutional openings intersecting a network of diffuse fractures is shown in figure 23 . These types of formations often are referred to as a "dual-porosity" formations because of the distinct hydraulic characteristics of different types of void space in the formation (Barenblatt and others, 1960).

The equations and boundary conditions geverning the pumping of water from a well in a " $\mathrm{c}$ "xalporosity" formation are shown in figure 23 . In this description of fluid withdrawal from the formation, the formation is assumed to be homogeneous and isotropic, and the pumping well is assumed to fully penetrate the formation. Although the Madison aquifer in the study area is known to have preferred orientation to it: structural features and dissolution openings, hypothesizing anisotropy and/or heterogeneity in the formation is not plausible, because only one observation well is available. In the description of the formation given in figure 23, there are four physical parameters: $T$, the transmissivity of the solutional openings; $S$, the storativity of the solutional openings; $S_{f}$, the storativity of the network of diffuse fractures; and $\beta$, the rate of fluid exchange between the network of fractures and the solutional openings.

To estimate the formation properties, the equations in figure 23 were solved with choices of $T, S, S_{f}$, and $\beta$, with type curves that were compared with the drawdown data (fig. 22) until a suitable fit was achieved. This method of curve fitting is similar to that described by Theis (1935). Values of $T, S, S_{f}$, and $\beta$, estimated from the curve-fitting procedure are: $T=$ $41,700 \mathrm{ft}^{2} / \mathrm{d}, S=3.0 \times 10^{-4}, S_{f}=1.5 \times 10^{-3}$, and $\beta=$ $1.7 \times 10^{-3} \mathrm{~d}^{-1}$. 


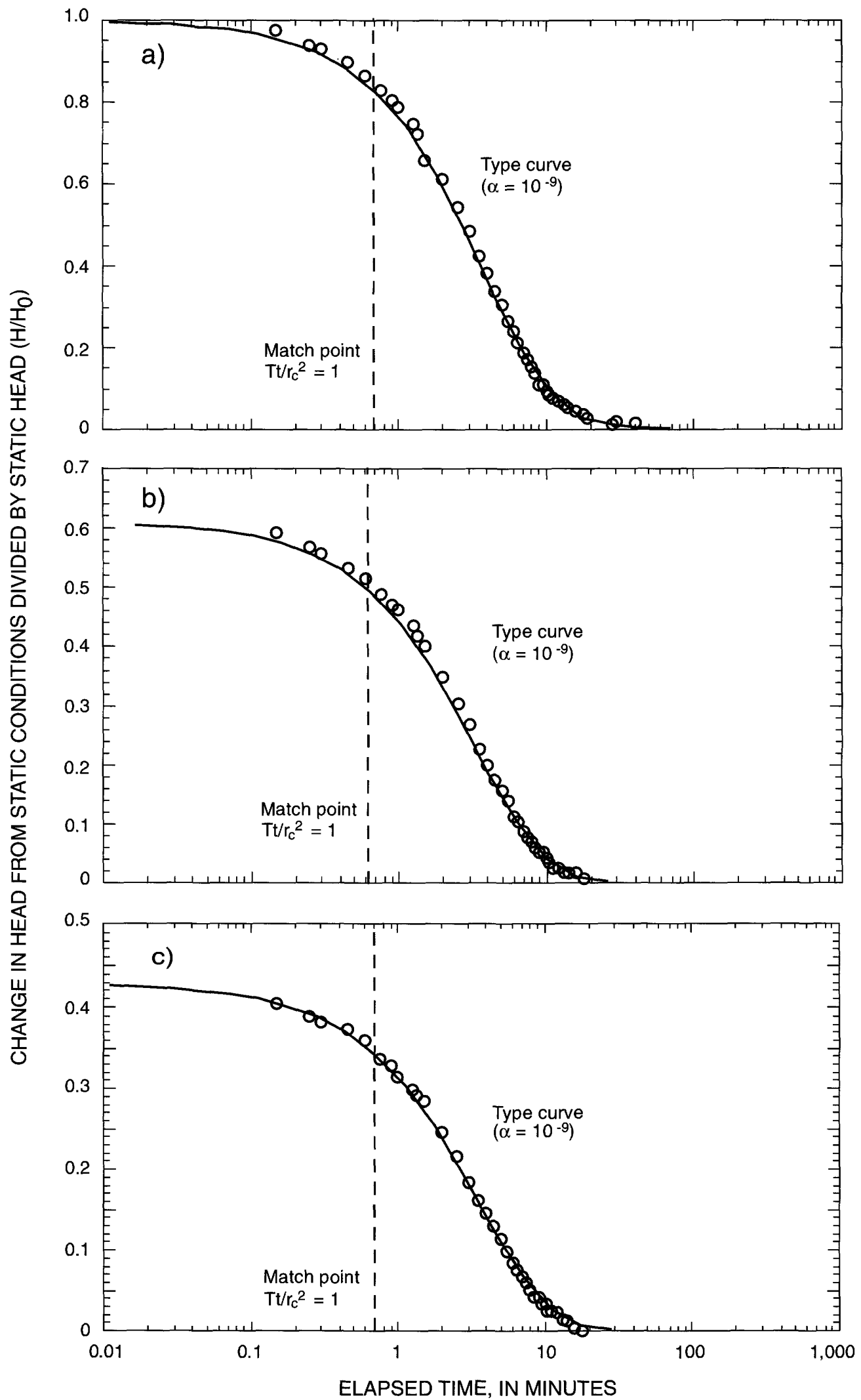

Figure 21. Best fit type curve match to the drawdown data from the air-pressurized slug tests conducted in observation well LA-88A at a) $100 \%$, b) $61 \%$, and c) $43 \%$ of the equilibrium water level, using an applied air pressure of 5 pounds per square inch. 


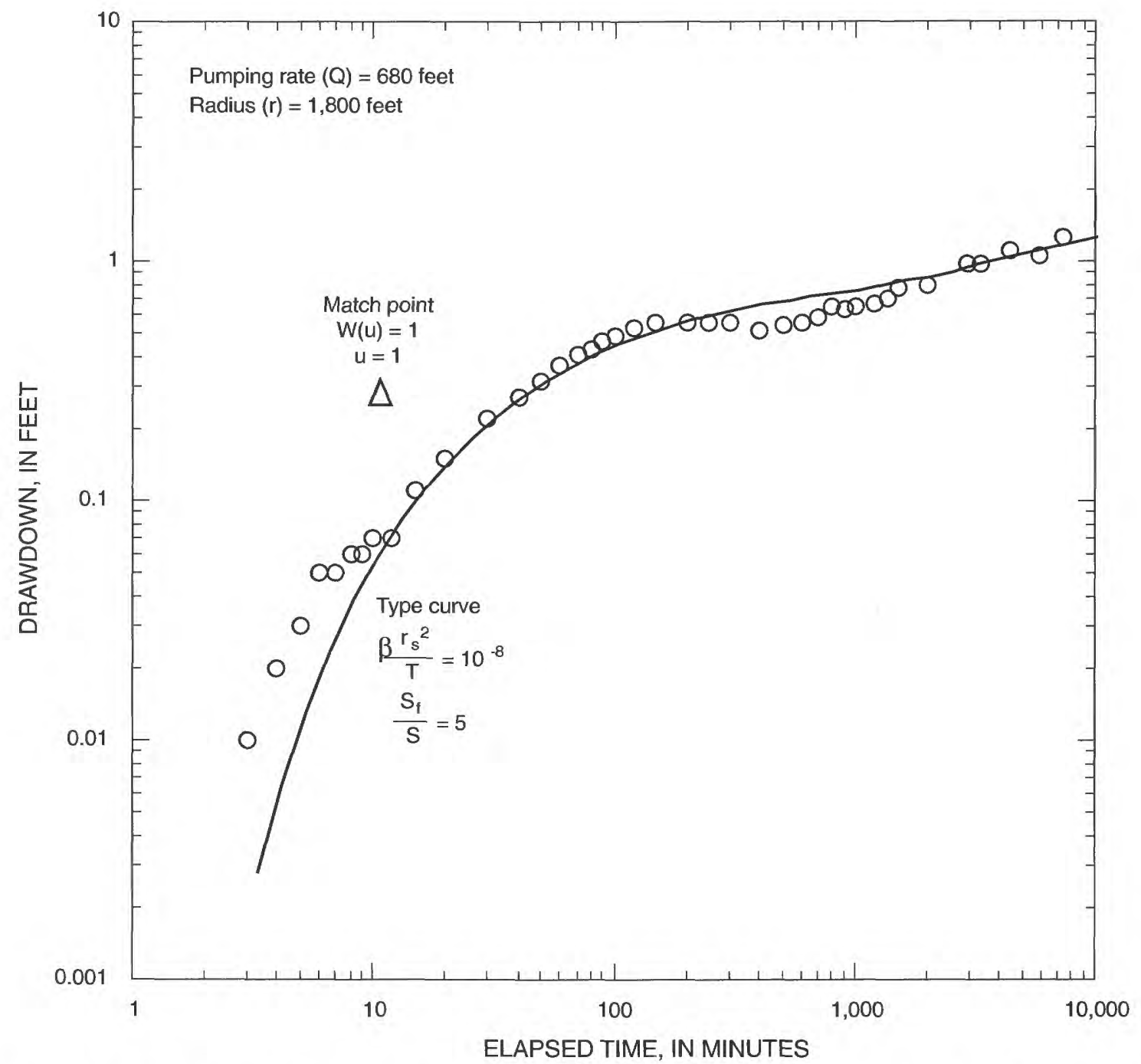

Figure 22. Best fit type curve match to the drawdown data obtained at the Kyte well from the Dickey well interference test in the Madison aquifer.

\section{Specific-Capacity Tests}

At the College, Dickey, Ellingson, and Nevin wells, specific-capacity (constant-discharge) aquifer tests were conducted by pumping water and measuring the drawdown in the pumped well. For the test conducted at the Dickey well, drawdown also was measured at a well completed in the Madison aquifer, and these results were interpreted in the previous section. The drawdown measured at the pumped wells, however, equilibrated almost immediately to the maximum drawdown for the applied pumping rate. Under such conditions, standard procedures of estimating formation properties using the time rate of drawdown cannot be employed. However, estimates of the transmissivity can be made from the specific-capacity. measurements in the pumped well (see, for example, Lohman, 1972; Bradbury and Rothschild, 1985); specific capacity is the ratio of the pumping rate to the drawdown (Bear, 1979).

The method of estimating transmissivity from specific-capacity data relies on assuming a value for storativity. To estimate the transmissivity from the specific-capacity tests conducted at the College, Dickey, Ellingson, and Nevin wells, a range of storativity values were used to illustrate the effect of plausible values of storativity on the estimates of transmissivity. The range of storativity values were based on the storativity estimated from the interpretation of the drawdown data at the Kyte well due to pumping at the Dickey well (see the discussion in the previous section). 


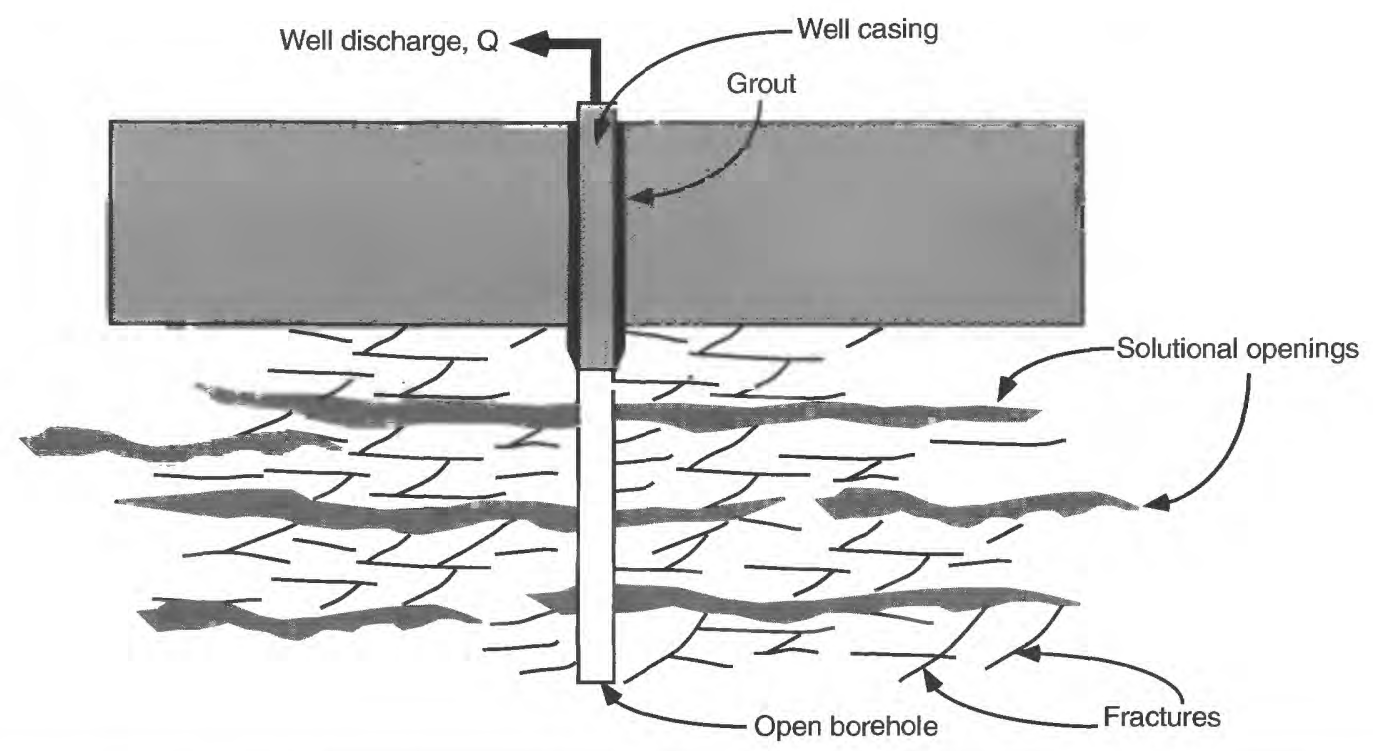

Flow in solutional openings:

$$
S \frac{\partial h}{\partial t}-T \frac{1}{r} \frac{\partial}{\partial r}\left(r \frac{\partial h}{\partial r}\right)=\beta\left(h_{f}-h\right)
$$

Initial condition in solutional openings:

$$
h(r, t=0)=H
$$

Boundary conditions in solutional openings:

$$
\begin{aligned}
& \left.2 \pi r T \frac{\partial h}{\partial r}\right|_{r \rightarrow 0}=Q \\
& h(r \rightarrow \infty, t)=H
\end{aligned}
$$

Flow in fractures:

$$
s_{f} \frac{\partial h_{f}}{\partial t}=-\beta\left(h_{f}-h\right)
$$

Initial condition in fractures:

$$
h_{f}(r, t=0)=H
$$

Figure 23. Conceptual model of ground-water flow to a well pumping in a unit formation consisting of solutional openings and a network of diffuse fractures.

Because the pumping rates used in the College, Dickey, Ellingson, and Nevin wells are large (more than several hundred gallons per minute), turbulent conditions in the well may result in turbulent head losses in the well. To estimate the transmissivity, it is necessary to estimate the drawdown in the formation by subtracting the drawdown attributed to the turbulent head losses in the well. This usually is done by first performing a step-drawdown test, where the pumping rate is increased in steps and the drawdown is measured at each step in the pumping rate (Rorabaugh, 1953; Bierschenk, 1963). If the drawdown in the pumped well is entirely attributed to the hydraulic properties of the aquifer and there is no turbulent head loss in the well, then the specific drawdown $\left(s_{w} / Q\right)$ is constant with each step in the pumping rate, where $s_{w}$ is the drawdown in the well and $Q$ is the pumping rate. However, if the turbulent head losses affect the measured drawdown in the pumped well, then $s_{w} / Q$ varies as a function of $Q$. Several authors have investigated turbulent head losses and have shown them to vary as a function of $Q^{2}$ (Rorabaugh, 1953; Bierschenk, 1963). If turbulent head losses are important, a plot of $s_{w} / Q$ versus $Q$ from step-drawdown tests should yield a straight line where the slope of the line is the turbulent head loss coefficient, $C$.

A step-drawdown test was conducted in the Nevin well. The result of this test is shown in figure 24, which shows that the turbulent head loss coefficient, $C$, is nonzero; this indicates that turbulent head losses in 

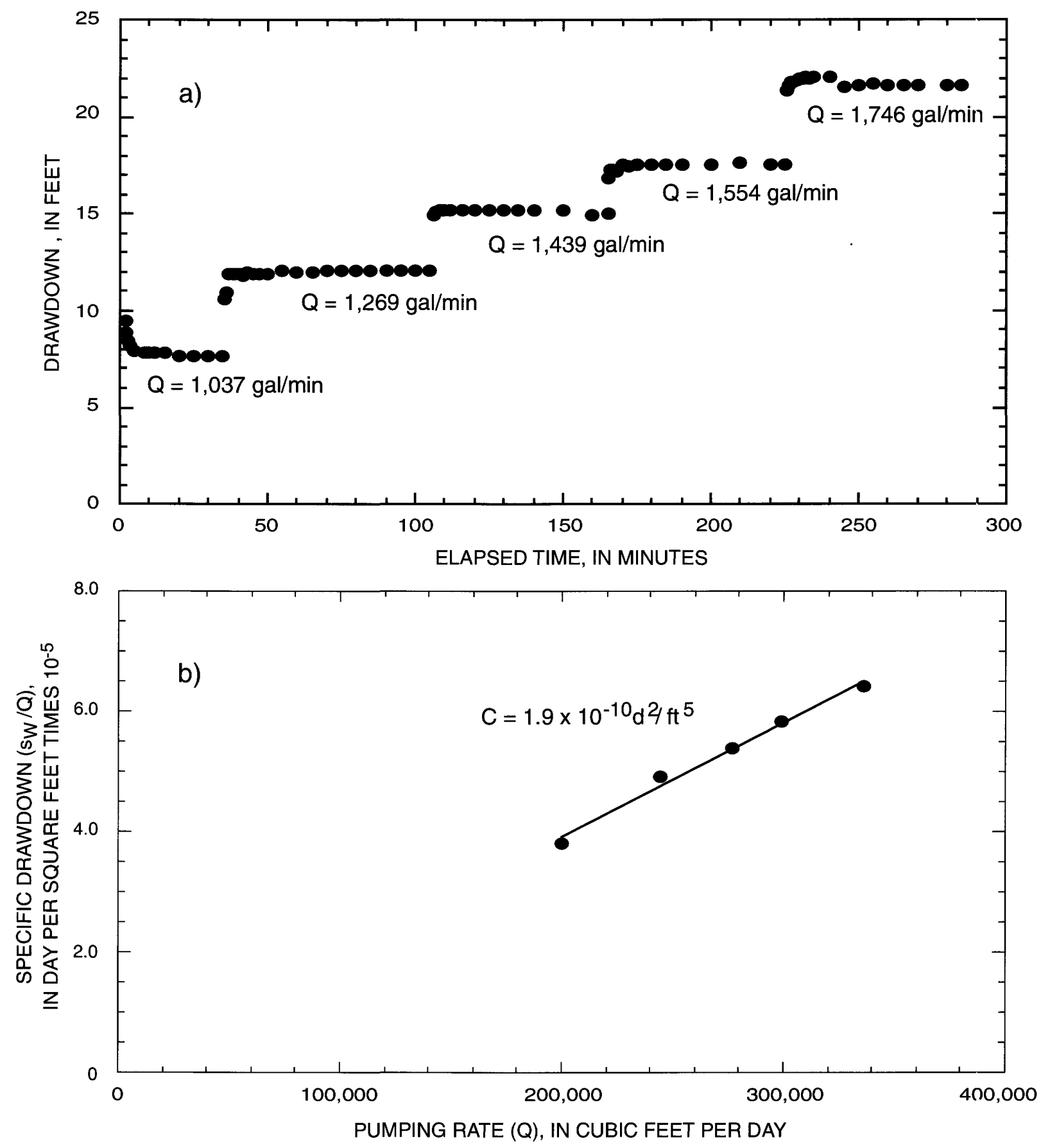

Figure 24. Step-drawdown test conducted in the Nevin well a) time versus drawdown data for a given pumping rate and $b$ ) determination of the turbulent head loss coefficient, $C$. 
the well are an important factor when considering the drawdown in the pumped well. Although step-drawdown tests were not conducted in the College, Dickey, and Ellingson wells, the turbulent head loss coefficient estimated from the Nevin well was used in estimating the transmissivity from specific-capacity tests conducted in the other wells. If the assumed value of $C$ for the College, Dickey, and Ellingson well is different than the actual value, the resulting transmissivity could be in error.

Table 3 gives the results of estimating transmissivity from the specific-capacity tests conducted in the College, Dickey, Ellingson, and Nevin wells using the methods described in Lohman (1972) and Bradbury and Rothschild (1985). The method of estimating transmissivity is based on assuming a storativity for the formation. Table 3 shows estimates of transmissivity using a range of storativity values. A storativity of approximately $10^{-4}$ was obtained from the interpretation of the drawdown measured in the Kyte well due to pumping in the Dickey well. Changing this value of storativity by an order of magnitude only changes the estimate of the transmissivity by approximately 15 percent.

With the exception of the transmissivity estimated for the Nevin well, the estimates of the transmissivity in table 3 all appear reasonable considering previous investigations of hydraulic properties of the Madison aquifer in the vicinity of the Black Hills of South Dakota (see, for example, Greene. 1993). The transmissivity estimated from the specific-capacity test in the Nevin well is unrealistic. Because of the large pumping rate and the large solutional openings near the well, it is likely that turbulent flow condit:ons extend into the formation, and therefore the radius of well $(0.42 \mathrm{ft})$ is not appropriate in estimating the transmissivity. Furthermore, the method of estimating transmissivity from specific-capacity data is based on the assumption of radial flow in a porous medium.

Because the Nevin well is completed in solutional openings in the Madison aquifer, it is likely that the well intersects a cavernous opening that ants more like a pipe or conduit than a porous medium. Consequently, the large value of the transmissiv ty estimated from the specific-capacity test in the Nevin well is considered invalid for predicting well yields and drawdowns in the Madison aquifer due to pumping in the Spearfish area.

Because step-drawdown tests were not conducted in each of the wells, a single value of the coefficient of turbulent head loss in the wells was used in estimating the transmissivity from the specificcapacity data. This turbulent head-loss coefficient was based on a step-drawdown test conducted in the Nevin well. Coefficients of turbulent head loss, however, can change dramatically from well to well, depending on the conditions of the pump and the construction of the well. Larger values of the turbulent head loss coefficient would result in larger estimates of the transmissivity. Similarly, smaller vahues of the turbulent head loss coefficient would yield smaller values of the transmissivity. Without conducting step-drawdown tests in the College, Dickey, and Ellingson wells, it is difficult to judge the accuracy of the estimated transmissivity values from the tests in these wells.

Table 3. Estimated transmissivity from analysis of specific-capacity tests completed in the College, Dickey, Ellingson, and Nevin wells

[Radius of all wells is assumed to be 0.42 foot. Time at which drawdown stabilizes is assumed to be 0.3 days for all wells. Turbulent head loss coefficient estimated from a step-drawdown test in the Nevin well is $C=1.9 \times 10^{-10} \mathrm{~d}^{2} / \mathrm{ft}^{5}$, and is assumed to be the same in all wells. $\mathrm{S}$, storativity]

\begin{tabular}{|c|c|c|c|c|c|}
\hline \multirow{2}{*}{ Well } & \multirow{2}{*}{$\begin{array}{c}\text { Pumping rate } \\
\text { (gallons per minute) }\end{array}$} & \multirow{2}{*}{$\begin{array}{l}\text { Measured drawdown, } \\
\text { (feet) }\end{array}$} & \multicolumn{3}{|c|}{$\begin{array}{c}\text { Transmissivity } \\
\text { (feet squared per day) }\end{array}$} \\
\hline & & & $S=10^{-5}$ & $S=10^{-4}$ & $S=10^{-3}$ \\
\hline College & 1,500 & 32.0 & 26,200 & 22,700 & 19,200 \\
\hline Dickey & 680 & 55.0 & 5.900 & 5,100 & 4,200 \\
\hline Nevin & 1.746 & 21.6 & $4,620,000$ & $4,150,000$ & $3,680,000$ \\
\hline
\end{tabular}




\section{Air-Pressurized Slug Test}

Two air-pressurized slug tests were conducted in the Madison aquifer at observation well LA-88C (fig. 17). In both tests, the pressurized part of the test was terminated prior to achieving an equilibrium water level. Thus, the data from these tests were interpreted using the method presented by Shapiro and Greene (1995). In the first test, the column of air in the well was pressurized for 100 minutes (56 percent of the equilibrium water level), and in the second test the well was pressurized for 360 minutes ( 87 percent of the equilibrium water level). The type curve match for these tests and results are shown in figure 25 . The estimates for transmissivity and storativity from both tests were $0.9 \mathrm{ft}^{2} / \mathrm{d}$, and $1.1 \times 10^{-3}$, respectively. The data from these tests are presented in table 11 in the Supplemental Information section.

Observation well LA-88C penetrates about $110 \mathrm{ft}$ into the Madison aquifer, which is the estimated permeable part of the aquifer (Greene, 1993). Therefore, the estimates of $T$ and $S$ from the air-pressurized slug tests conducted in this well did not need to be extrapolated to apply to the entire aquifer thickness.

\section{Summary of Aquifer Hydraulic Prope-ties}

A summary of the hydraulic properties estimated from the aquifer tests conducted in the Minnelusa and Madison aquifers is given in table 4 . In the case of partially penetrating wells, the estimates of $T$ and $S$ have been extrapolated to represent the assumed thickness of the aquifer. In addition, for each test, the lengtl of the scale associated with the hydraulic properties is presented to aid in interpreting the results. At sites where more than one test was conducted, the results in table 4 are an average of the estimated values from the tests.

\section{Transmissivity}

In the Minnelusa aquifer, the transmissivity estimated from the interference test at the golf course well was $9,600 \mathrm{ft}^{2} / \mathrm{d}$. This transmissivity estimate was based on drawdown measured in observation well LA-88B, located 1,200 ft from the pumped well. In comparison, the transmissivity estimates from airpressurized slug tests conducted in wells LA-87A, LA-88B, and LA-88A were more than an order of magnitude less, ranging from 125 to $396 \mathrm{ft}^{2} / \mathrm{d}$ (table 4).

Table 4. Summary of hydraulic properties from aquifer tests conducted in the Minnelusa and Madison aquifers near Spearfish, S. Dak.

\begin{tabular}{|c|c|c|c|}
\hline Well & $\begin{array}{c}\text { Transmissivity } \\
\text { (feet squared per day) }\end{array}$ & $\begin{array}{c}\text { Storativity } \\
\text { (dimensionless) }\end{array}$ & $\begin{array}{l}\text { Length scale of estimate } \\
\text { (feet) }\end{array}$ \\
\hline \multicolumn{4}{|c|}{ Minnelusa aquifer } \\
\hline \multicolumn{4}{|l|}{ Interference test } \\
\hline Golf course & 9.600 & $7 \times 10^{-5}$ & $1,000-2,000$ \\
\hline \multicolumn{4}{|c|}{ Air-pressurized slug tests } \\
\hline LA-87B & 125 & $\left({ }^{1}\right)$ & Few feet around borehole \\
\hline LA-88B & 185 & $6.0 \times 10^{-9}$ & Few feet around borehole \\
\hline LA-88A & 396 & $4.0 \times 10^{-9}$ & Few feet around borehole \\
\hline \multicolumn{4}{|c|}{ Madison aquifer } \\
\hline \multicolumn{4}{|l|}{ Interference test } \\
\hline Dickey & 41,700 & $3 \times 10^{-4}$ & $1,000-2,000$ \\
\hline \multicolumn{4}{|c|}{ Specific-capacity tests } \\
\hline College & 22,700 & ${ }^{2} 1 \times 10^{-4}$ & Tens of feet around borehole \\
\hline Dickey & 5,100 & ${ }^{2} 1 \times 10^{-4}$ & Tens of feet around borehole \\
\hline Ellingson & 2,900 & ${ }^{2} 1 \times 10^{-4}$ & Tens of feet around borehole \\
\hline Nevin & $\left({ }^{1}\right)$ & ${ }^{2} 1 \times 10^{-4}$ & Tens of feet around borehole \\
\hline \multicolumn{4}{|c|}{ Air-pressurized slug tests } \\
\hline LA-88C & 0.9 & $1 \times 10^{-3}$ & Few feet around borehole \\
\hline
\end{tabular}

${ }^{1}$ Unrealistic value from hydraulic test.

${ }^{2}$ Assuming $S=1 \times 10^{-4}$. 


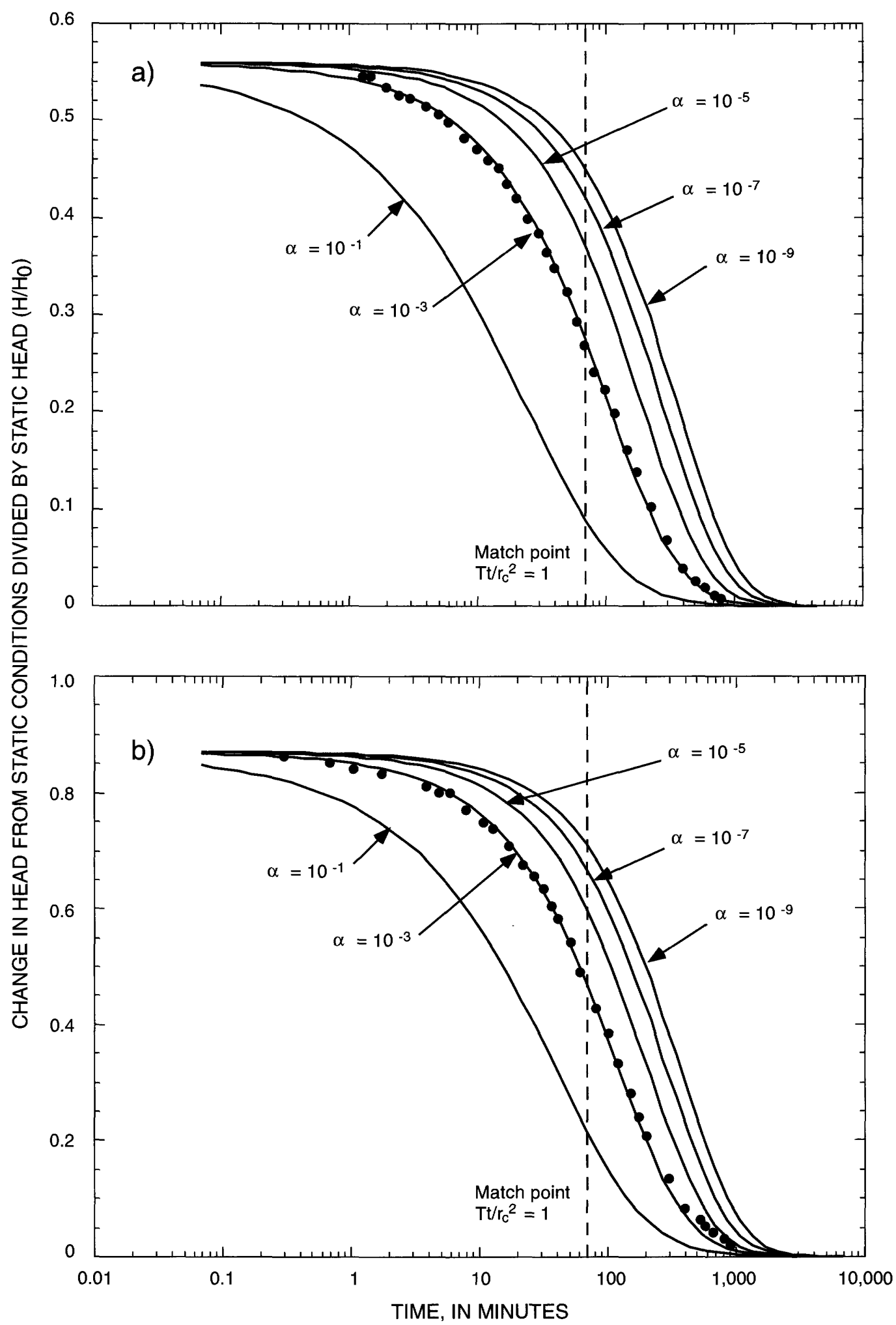

Figure 25. Best fit type curves to the drawdown data from air-pressurized slug tests conducted in observatior well LA-88B at a) $56 \%$ and b) $87 \%$ of the equilibrium water level, using an applied air pressure of 4.1 pounds per s suare inch. 
The interpretation of the air-pressurized slug test conducted in LA-88B yielded a value of $185 \mathrm{ft}^{2} / \mathrm{d}$, while the interpretation of drawdown in the same well due to pumping in the golf course well yielded a value of $9,600 \mathrm{ft}^{2} / \mathrm{d}$. This illustrates that slug tests, which hydraulically stress only a small volume of the formation, likely do not test the high-permeability pathways in the Minnelusa aquifer. Thus, the estimates of transmissivity from air-pressurized slug tests are representative of a few feet around the tested wells, and these estimates of transmissivity cannot be used when considering larger scale ground-water flow in the Minnelusa aquifer.

The difference in the transmissivity from the slug tests and the interference test illustrates the heterogeneity present in the Minnelusa aquifer. The interference test conducted in the golf course well stressed a volume large enough to include structurally induced high-permeability zones in the Minnelusa Formation. Between the golf course well and observation well LA-88B, it is likely that there are hightransmissivity zones that exceed the estimated transmissivity $\left(9,600 \mathrm{ft}^{2} / \mathrm{d}\right)$; the estimate of transmissivity from this test is most likely an average of the heterogeneous transmissivity between the golf course well and observation well LA-88B. Without additional wells and aquifer testing, the range of transmissivity in the Minnelusa aquifer cannot fully be identified.

The transmissivity estimated from aquifer tests conducted in the Madison aquifer indicates that the scale of the test has a similar effect on the estimate of the transmissivity. The transmissivity estimated from the interference test at the Dickey well was $41,700 \mathrm{ft}^{2} / \mathrm{d}$. This transmissivity estimate was based on drawdown measured in the Kyte well, located $1,800 \mathrm{ft}$ from the pumped well. In comparison, the transmissivity estimates from specific-capacity tests ranged from 2,900 to $22,700 \mathrm{ft}^{2} / \mathrm{d}$ (table 4 ). The transmissivity estimated from the specific-capacity test in the Dickey well $\left(5,100 \mathrm{ft}^{2} / \mathrm{d}\right)$ was nearly one order of magnitude less than the transmissivity estimated from the interference test $\left(41,700 \mathrm{ft}^{2} / \mathrm{d}\right)$, which illustrates the heterogeneity present in the Madison aquifer. The Dickey well may be located in a lower permeability area of the formation, whereas the drawdown at the Kyte well provides information about the hydraulic characteristics of the formation over larger distances.

The transmissivity of the Madison aquifer estimated from the air-pressurized slug test conducted at well LA-88C is several orders of magnitude less than estimates of $T$ from either the specific-capacity tests or the interference test. This illustrates that slug tests, which hydraulically stress only a small volume of the formation, likely do not test the high permeability fractures or solutional openings in the Madison aquifer.

\section{Storativity}

Storativity $(S)$ determined from aquifer terting in the Minnelusa and Madison aquifers varies over six orders of magnitude from $1 \times 10^{-3}$ to $4 \times 10^{-9}$ (tak 1 e 4 ). The typical range of $S$ for confined aquifers usually is about $10^{-3}$ to $10^{-5}$ (Lohman, 1972).

In the Minnelusa aquifer, $S$ estimated from the interference test at the golf course well was $7.4 \times 10^{-5}$. This storativity estimate was based on drawdown measured in the observation well LA-88B, located $1,200 \mathrm{ft}$ from the pumped well. In comparison, the $S$ estimates from air-pressurized slug tests conducted in we'ls LA-88B and LA-88A were four orders of magnitude less. The estimate for $S$ from the air-pressurize $d$ slug tests conducted in well LA-87B yielded an unrealistically high value for a confined aquifer. This illustrates that the storativity values estimated from slug te:ts may not be reliable because they hydraulically stress only a small volume of the formation.

In the Madison aquifer, $S$ estimated from the interference test at the Dickey well was $3 \times 10^{-4}$. In comparison, the $S$ estimate from air-pressurized slug tests at LA-88C was about one order of magnitude greater $\left(1 \times 10^{-3}\right)$.

\section{SYNTHESIS OF HYDROLOGIC INFORMATION}

Numerical simulation of ground-water flow is a useful tool for investigating problems involving hydrologic systems. The numerical simulation of the Minnelusa and Madison aquifers for this study was not conducted to predict scenarios for water-resource evaluation in the Minnelusa and Madison aquifers near Spearfish, but rather to synthesize the hydrolog $:$ information collected to date from these two aquifers. The numerical simulation illustrates the value of urderstanding recharge, withdrawals, and transmissivity in quantifying the ground-water flow in an aquife* system. In addition, the numerical simulation illustrates where additional information is needed if predictive models of ground-water flow and resource evaluation are to be developed at a later date. The 
following section briefly describes the theory, limitations, and data used in the ground-water simulations of the Minnelusa and Madison aquifers.

\section{Theory and Assumptions}

The numerical models of ground-water flow in the Minnelusa and Madison aquifers that were prepared for this report assume steady-state ground-water flow of a constant density fluid. Although the hydraulic heads in the Minnelusa and Madison aquifers vary with time, the assumption of steady-state flow implies that a long-term average of the ground-water fluxes into and out of these formations was considered. In addition, because hydrologic information presented earlier does not indicate significant hydraulic connection between the Minnelusa and Madison aquifers in the Spearfish area, ground-water flow in each of these aquifers was considered separately. Furthermore, it was assumed that ground-water flow is essentially parallel to the beds of the formations and thus, vertical components of ground-water flow were assumed to be negligible. Under these assumptions, the equation describing the conservation of the volume of fluid at any point is given by:

$$
\frac{\partial}{\partial x}\left(\frac{T_{x} \partial h}{\partial x}\right)+\frac{\partial}{\partial y}\left(\frac{T_{y} \partial h}{\partial y}\right)=W(x, y)
$$

where $h$ is the hydraulic head, $T_{x}$ and $T_{\mathrm{y}}$ are the transmissivities of the aquifer in the $x$ - and $y$-directions, respectively, and $W_{\mathrm{x}}$ and $W_{y}$ are the volumetric rates of fluid recharge or discharge per unit area of the aquifer. For example, $W\left({ }_{x y}\right)$ can represent recharge to the formation due to precipitation or streamflow losses, and/or discharges due to pumping. Equation 1 implies that the principal directions of the transmissivity are oriented along the $x$ - and $y$-axes, respectively, and the transmissivities and the sources or sinks of fluid volume can vary from point to point in the aquifer. Hydraulic head $(h)$ in a ground-water flow model is dependent on the ratio of $\frac{W}{T}\left(\frac{\text { recharge and discharge }}{\text { transmissivity }}\right)$.

Equation 1 is applicable at all points over the areal extent of the Minnelusa and Madison aquifers. Solving equation 1 for the spatial distribution of the hydraulic head requires boundary conditions, which will be discussed in the following sections for the Minnelusa and Madison aquifers. Because of the complex geometry of the aquifers, the spatial variation of transmissivity, and the spatial variation of fluid sources and sinks, numerical methods were used to solve equation 1 for the spatial distribution of the hydraulic head in the Minnelusa and Madison aquifers. For this report, the USGS modular ground-water f'ow model (MODFLOW) developed by MacDonald and Harbaugh (1988) was used for the simulations.

The numerical solution of equation 1 is based on a finite-difference approximation, where the areal domain is divided into a number of rectangular cells and the conservation of fluid volume within each cell is considered. Cell properties, such as transmissivity and recharge, can vary from cell to cell. For the groundwater simulations in this report, volumetr:c rates of recharge to, or discharge from, the aquifers were estimated and spatially distributed based on hydrologic information from the study areas, and a spatial distribution of the transmissivity was specified.

The Madison aquifer is a karst aquifer throughout the Black Hills, and ground-water flow is not always strictly governed by the principles of porous media. Thus, transmissivity assigned to a cell is a cellaveraged value and simply averages the variability of hydraulic properties from the karst system.

To prescribe a spatial distribution of the transmissivity for the numerical simulation of ground-water flow, results from aquifer tests could be $\mathbf{u}$ ced as a starting point to constrain the transmissivity. However, based on the aquifer tests that were conducted in the Minnelusa and Madison aquifers, the hydraulic properties were shown to be highly heterogeneous and dependent on the scale of the test that was conducted.

Consequently, applying these transmissivity values for the purpose of simulating ground-water flow would depend on the scale of the simulation. In simulating regional ground-water flow in the Minnel'ssa and Madison aquifers in the Spearfish area, even values of transmissivity from those aquifer tests that affected distances greater than $1,000 \mathrm{ft}$ may not be suitable for characterizing ground-water flow over distances of several miles. Therefore, instead of using the aquifer test results, estimates of the transmissivity were made based on assumptions regarding recharge and withdrawal estimates for the aquifer and the spatial distribution of the potentiometric surface. The complexity of the spatial distribution of the transmissivity for the numerical simulations was considered only to the extent that was needed to reproduce the general behavior of the potentiometric surface. Therefore, estimates of transmissivity from numerical simulations were independent of estimates of transmissivity from the interpretation of aquifer tests. 
Although the simulation of ground-water flow in the Minnelusa and Madison aquifers in this report was not intended for predictive purposes, it was still necessary to determine if the simulations reflect the groundwater flow conditions in these aquifers. For this purpose, the hydraulic heads that have been mapped from wells completed in the Minnelusa and Madison aquifers were used for comparison with the model results. It was assumed that the mapped hydraulic heads (figs. 8 and 11) represent steady-state flow conditions in the aquifers, even though these aquifers show transient conditions. Because of the lack of detailed information concerning several of the hydrologic inputs, a rigorous matching between the measured and modeled hydraulic heads was not performed. Instead, the spatial distributions of model parameters were chosen to reproduce the general spatial trends in the measured hydraulic-head data. For modeling purposes, recharge to the Minnelusa aquifer was assumed to be from areal precipitation. Recharge to the Madison aquifer was assumed to be from streamflow losses where drainage basins intersect the outcrop.

\section{Minnelusa Aquifer}

This section describes a numerical simulation of steady-state ground-water flow in the Minnelusa aquifer near Spearfish. Numerical modeling of the Minnelusa aquifer was conducted to develop an understanding of the recharge/transmissivity relation and transmissivity distribution in the study area. In addition, the numerical simulations were intended to provide additional insight on the role of geologic structures on ground-water movement in the Spearfish area.

\section{Model Domain, Boundary Conditions, and Parameter Values}

The model domain used to simulate groundwater flow in the Minnelusa aquifer is shown in figure 26. The domain size is considerably larger than the immediate vicinity of the City of Spearfish so that well-defined hydrologic boundaries in the Minnelusa aquifer can be considered in the simulations. The extension of the potentiometric surface was modified from Kyllonen and Peter (1987) using water-level data in Wyoming.

For the purpose of explanation, the boundary of the model domain in figure 26 was marked by a series of points denoted as A, B, C, D, E, and F. These points denote segments along the boundary having different boundary conditions. Along segments A-F and B-C in figure 26, there was assumed to be no ground-water flow perpendicular to the boundary. These segments of the boundary are approximately perpendicular to potentiometric contours; in this area of the model domain, potentiometric contours are nearly parallel to the outcrop of the Minnelusa aquifer.

Segment D-E in figure 26 also was assumed to be a no-flow boundary because it is approximately perpendicular to potentiometric contours in the northern part of the model domain. The potentiometric contours in this area of the model domain characterize largescale regional ground-water flow in the Minnelusa aquifer extending from Wyoming into South Dakota.

In figure 26, segments C-D and E-F were assumed to be boundaries of fixed hydraulic head corresponding to the large-scale regional ground-water flow in the Minnelusa aquifer. Along segment C-D, the hydraulic head was assumed to be at an elevation of $3,150 \mathrm{ft}$ above sea level, whereas along segment E-F, the hydraulic head was assumed to be $3,500 \mathrm{ft}$ above sea level.

Segment A-B in figure 26 approximates the outcrop of the Minnelusa aquifer, and it was assumed to be a boundary where recharge was prescribed. This boundary was assumed to be the only source of groundwater recharge to the Minnelusa aquifer, which most likely is the result of streamflow losses and precipitation runoff from local drainage areas. Detailed studies of these processes, however, have not been conducted for the Minnelusa aquifer in this area. Therefore, certain assumptions regarding the magnitude and distribution of the recharge to Minnelusa aquifer were made to facilitate ground-water simulations.

Mean precipitation in the Spearfish area is approximately $22 \mathrm{in/yr}$ (Kyllonen and Peter, 1987). The area of the outcrop of the Minnelusa Formation in the vicinity of the model domain is approximately $43 \mathrm{mi}^{2}$. Thus, approximately $6.0 \times 10^{6} \mathrm{ft}^{3} / \mathrm{d}$ falls on the outcrop of the Minnelusa Formation; however, only a percentage of this volume of water was assumed to recharge the aquifer. For the purpose of ground-water simulations in this investigation, it was assumed that 1.5 percent of the precipitation recharges the Minnelusa aquifer, which is equivalent to about $90,000 \mathrm{ft}^{3} / \mathrm{d}$ along the boundary of the model domain. The percentage of precipitation that was assumed to recharge the Minnelusa aquifer is reasonable according to several authors (Rahn and Gries, 1973; Ghannam and Rahn, 1994); however, detailed investigations to estimate recharge rates to the Minnelusa aquifer based on independent observations have yet to be conducted. 


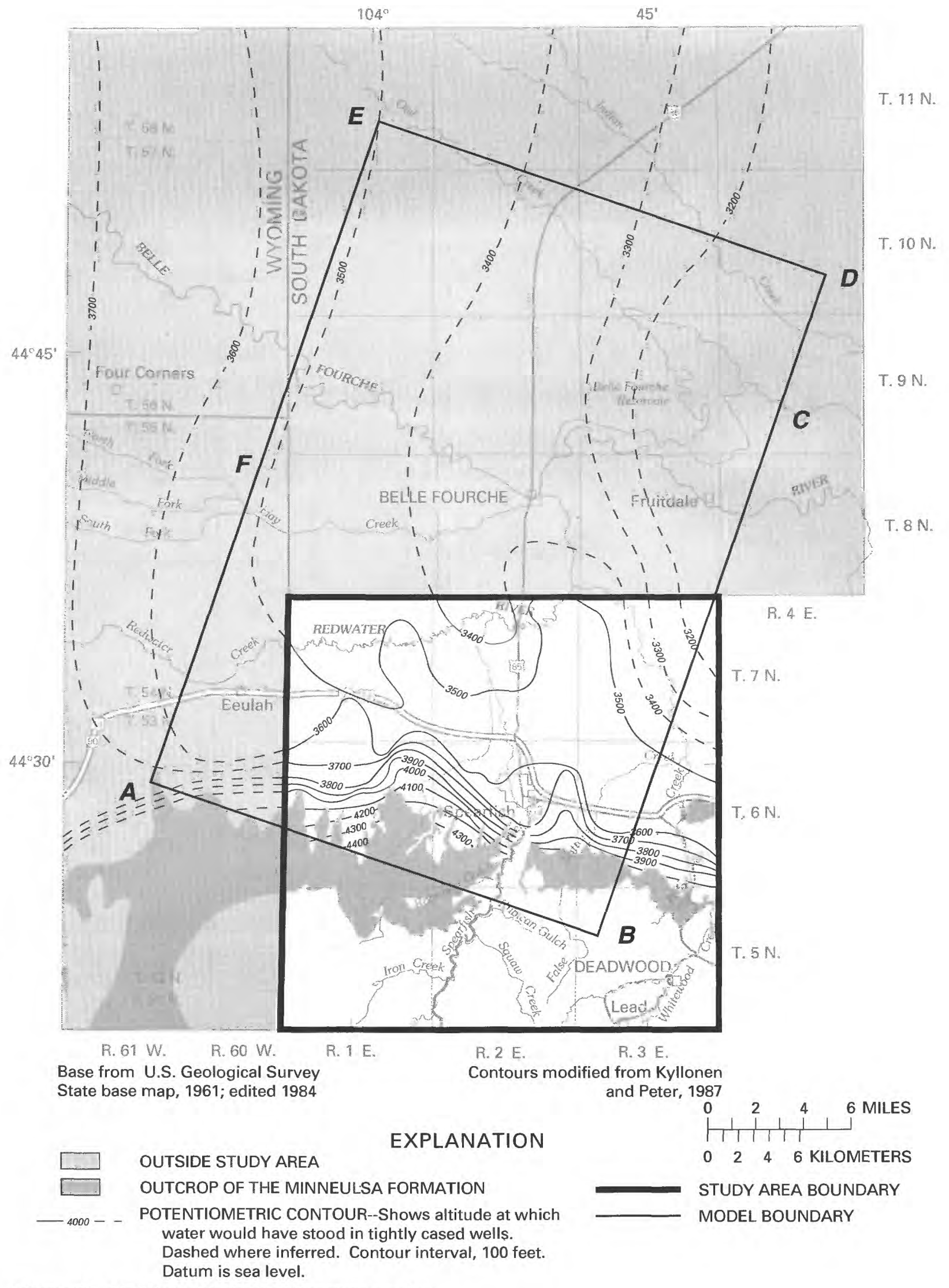

Figure 26. Model domain for the Minnelusa aquifer. 
Because there is no information on the spatial distribution of recharge to the Minnelusa aquifer in the Spearfish area, the volumetric rate of recharge was assumed to be evenly distributed along segment A-B in figure 26. In addition, streamflow losses to the Minnelusa aquifer were assumed to be negligible because most streams lose their entire flow along the outcrop of the Madison Limestone before crossing the outcrop of the Minnelusa Formation. One exception may be streamflow losses along Spearfish Creek due to the water diversion through the aqueduct. However, sufficient information is not available to estimate the water losses through the aqueduct that recharge the Minnelusa aquifer. Thus, all water losses through the aqueduct were considered to recharge the Madison aquifer.

The Minnelusa aquifer in the vicinity of Spearfish is used widely for livestock, domestic, and irrigation supply. Records on the total withdrawals from the Minnelusa aquifer were not available; however, for the purpose of ground-water simulations, estimates of ground-water withdrawals were made based on irrigation use in the study area (James Goodman, South Dakota Department of Environment and Natural Resources, oral commun., 1995). The rate of water withdrawal from pumping wells in the Minnelusa aquifer is very small and was assumed to be approximately $71,000 \mathrm{ft}^{3} / \mathrm{yr}$, evenly distributed over the areal extent of the Minnelusa aquifer in the model domain.

Ground-water discharges from springs in the model domain could significantly affect the estimated distribution of transmissivity. There are numerous large springs in the modeled area, such as along tributaries to the Redwater River. Although the springs may be from a variety of sources, for the purpose of the model the source of these springs is assumed to be the Madison aquifer. Therefore, ground-water discharges from springs were not included in the simulation of the Minnelusa aquifer.

Because steady-state ground-water flow was considered, values of storativity were not required in the ground-water simulations of the Minnelusa aquifer. However, a spatial distribution of transmissivity was needed. Based on the assumed distribution of groundwater recharge and withdrawals, the spatial distribution of transmissivity was chosen to reproduce the general trends in the measured hydraulic heads in the Minnelusa aquifer. The distribution of transmissivity will be discussed in detail in a subsequent section describing the results of the model simulations.

\section{Model Discretization}

For the purpose of simulating ground-water flow in the Minnelusa aquifer, the model domain shown in figure 26 was discretized into a rectangular grid containing 31 rows and 21 columns (fig. 27). The grid cells having a cross-hatched area in figure 27 are inactive cells within the model domain. In all, there are 603 active cells in the model domain. Each cell has an area of approximately $1 \mathrm{mi}^{2}$; thus, an area of approximately $603 \mathrm{mi}^{2}$ was considered in the ground-water simulations.

Active cells along the boundary of the outcrop of the Minnelusa Formation were assumed to be subject to the volumetric recharge associated with precipitation. Twenty-five cells along this boundary were assumed to recharge a total of $90,000 \mathrm{ft}^{3} / \mathrm{d}$. Because recharge was assumed to be evenly distributed along the boundary, each cell was assigned a recharge of $3,600 \mathrm{ft}^{3} / \mathrm{d}$ to the Minnelusa aquifer. The withdrawal of water from the Minnelusa aquifer was represented by specifying a volumetric discharge from each active cell equal to $1.2 \times 10^{-8} \mathrm{ft} / \mathrm{d}$ times the area of the cell.

\section{Ground-Water Simulations}

Using the values of recharge and ground-water withdrawals that were estimated for the Minnelusa aquifer, the distribution of the transmissivity used to reproduce the measured hydraulic heads is shown in figure 28. In general, four bands of transmissivity were used to reproduce the pattern of the hydraulic heads in figure 26. A relatively low transmissivity near the outcrop was needed with successive bands of higher transmissivity northward in the model domain. The transmissivity near the outcrop was assigned as $50 \mathrm{ft}^{2} / \mathrm{d}$, and a gradual increase in the transmissivity was used in successive bands farther from the outcrop. A much higher transmissivity zone of $3,000 \mathrm{ft}^{2} / \mathrm{d}$ in the northern part of the model domain (fig. 28) was used to simulate regional ground-water flow. In order to obtain the spatial variation in the hydraulic heads, high transmissivity zones $\left(1,000\right.$ to $\left.3,000 \mathrm{ft}^{2} / \mathrm{d}\right)$ representing the location of the mapped structural features near Spearfish (fig. 7) were included. This characteristic included a zone of very low transmissivity located between the two high transmissivity structural features. This zone of low transmissivity was assigned as $0.012 \mathrm{ft}^{2} / \mathrm{d}$, which is about five orders of magnitude less than the high transmissivity zone representing the structural features. 


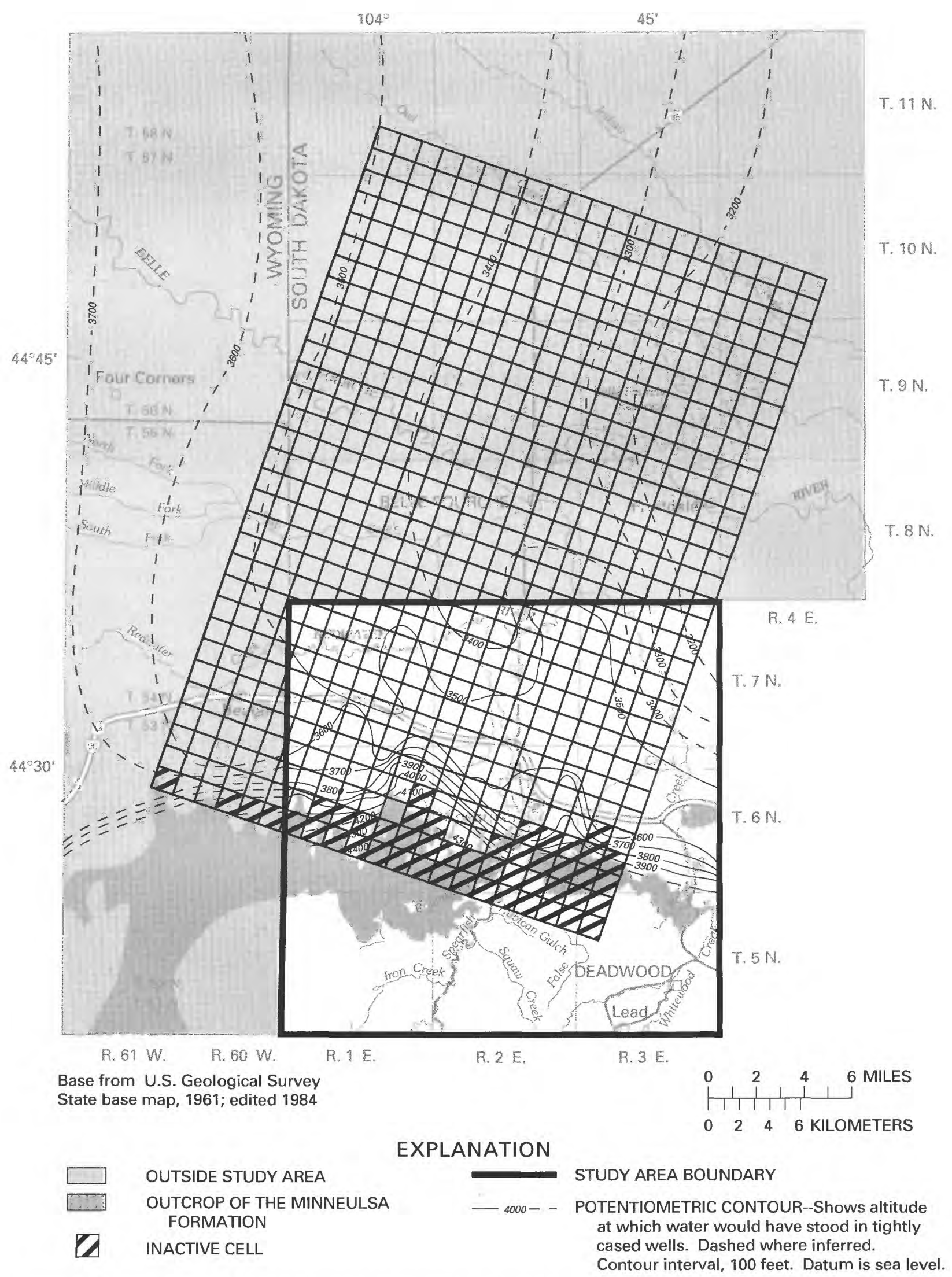

Figure 27. Finite-difference grid for numerical simulation of ground-water flow in the Minnelusa aquifer. 


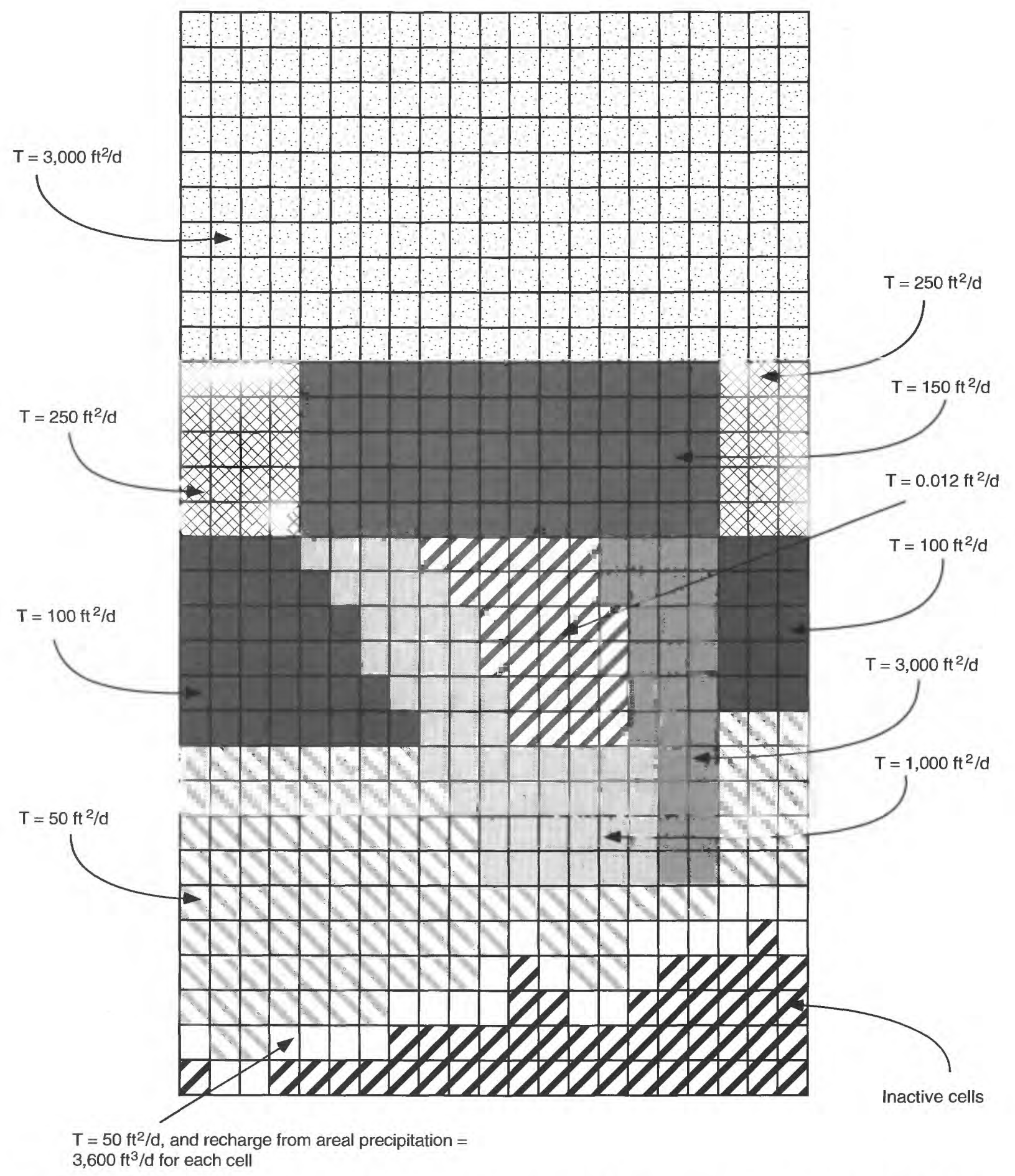

Figure 28. Distribution of transmissivity and recharge to reproduce the measured potentiometric surface of the Minnelusa aquifer. 
The simulated potentiometric surface is compared to the measured potentiometric surface in figure 29. This spatial distribution of transmissivity, in general, reproduces the measured potentiometric surface near Spearfish. To the west of Spearfish, the simulated hydraulic heads are higher than the measured hydraulic heads that have been interpolated in this area. The difference between the simulated hydraulic heads and the measured hydraulic heads could be the result of overestimating the recharge in this area, underestimating spring discharge, incorrect boundary conditions, or underestimating the transmissivity in this area.

Recharge rates used in the simulation of hydraulic heads in the Minnelusa aquifer are only estimates because investigations to quantify recharge have not been conducted. The actual recharge rates to the aquifer could be larger or smaller than those estimated in the simulations. To illustrate the effect of the recharge rates on the spatial distribution of transmissivity needed to reproduce the measured potentiometric surface, the original recharge rate of $90,000 \mathrm{ft}^{3} / \mathrm{d}$ was increased by 25 percent to $112,500 \mathrm{ft}^{3} / \mathrm{d}$. Using this value of recharge for cells along the outcrop, the values of transmissivity also were increased by 25 percent (fig. 30) to reproduce the measured potentiometric surface (fig. 31). This illustrates that by keeping the ratio of $\frac{W}{T}$ the same, the measured potentiometric surface can be reproduced. Therefore, accurate estimates of recharge are needed to estimate transmissivity.

\section{MEASURED POTENTIOMETRIC SURFACE}

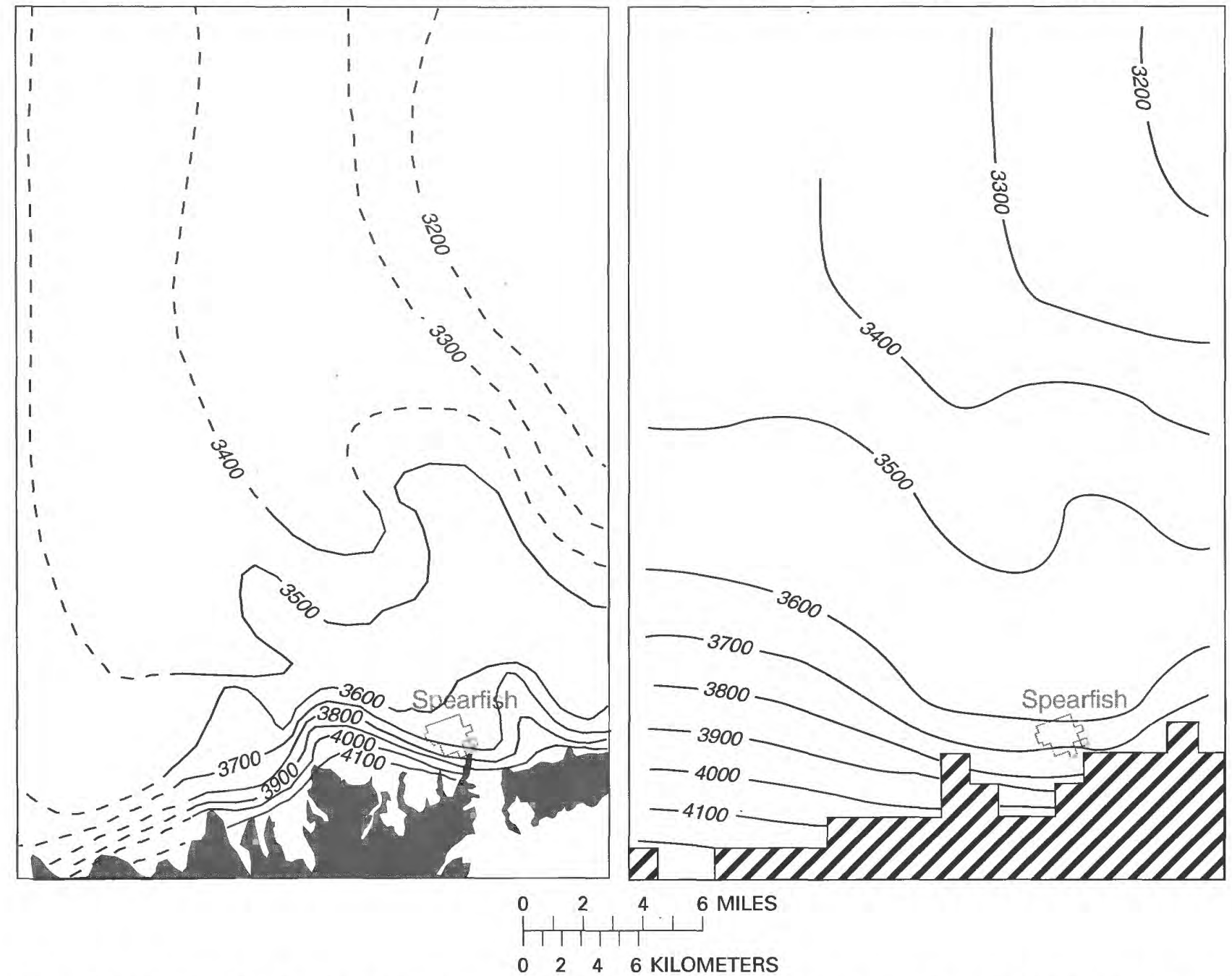

Figure 29. Measured and simulated potentiometric surfaces for the Minnelusa aquifer (simulation used a recharge rate of 90,000 cubic feet per day and the distribution of transmissivity shown in figure 28 ). 


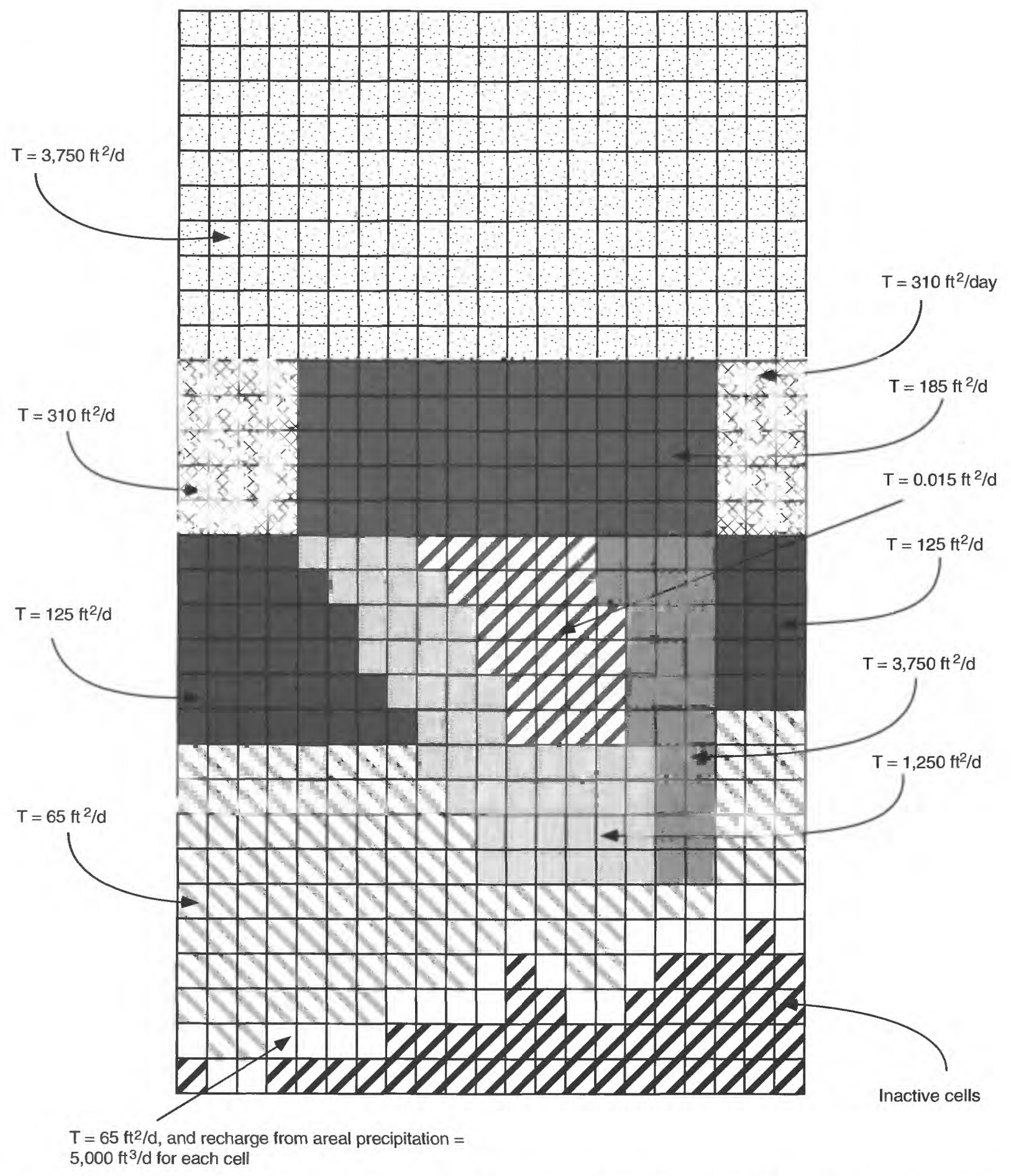

Figure 30. Distribution of transmissivity to reproduce the measured potentiometric surface of the Minnelusa aquifer after increasing the recharge rate by $25 \%$ to 112,500 cubic feet per day. 
MEASURED POTENTIOMETRIC SURFACE

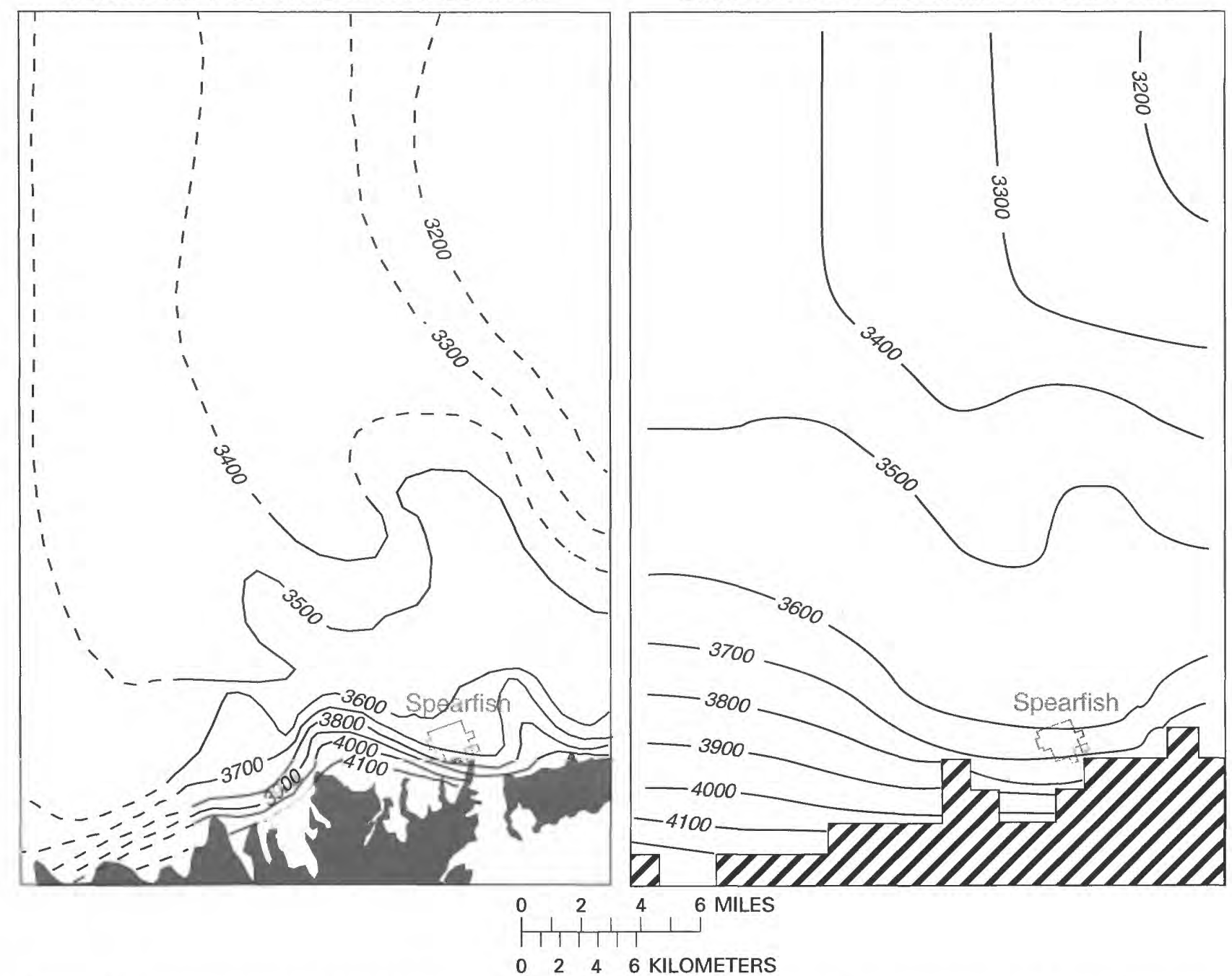

Figure 31. Measured and simulated potentiometric surfaces for the Minnelusa aquifer (simulation used a recharge rate increased by $25 \%$ and a distribution of transmissivity increased by $25 \%$ as shown in figure 30 ).

Without better estimates of recharge to the Minnelusa aquifer and better knowledge of the spatial distribution of recharge, the future development of predictive models of ground-water flow in the Spearfish area would be severely hampered. With uncertainty in estimates of recharge, there will be similar uncertainty in estimating the regional transmissivity, and thus, there will be uncertainty in the management of the ground-water resources in the Minnelusa aquifer in the Spearfish area.

As illustrated above, the absolute values of the transmissivity needed to characterize regional groundwater movement in the Minnelusa aquifer in the Spearfish area depend on the estimate of recharge.
Although there are questions concerning the estimate of the recharge to the Minnelusa aquifer, the simulations shown in this report indicate a general spatial distribution of transmissivity that could be anticipated. Model results are consistent with lower transmissivity values near the outcrop of the Minnelusa aquifer, and higher transmissivity values in the northern part of the modeled area. Higher transmissivity values also are associated with structural features.

If the estimates of recharge and withdrawals are assumed to be reasonable, then the estimates of transmissivity from aquifer tests can be compared with those obtained from the ground-water simulations. Based on the assumed recharge and withdrawals, the 
values of transmissivity used in the ground-water simulation represent the average hydraulic properties that will move volumes of water in the aquifer to produce the measured spatial distribution of hydraulic heads. The largest scale aquifer test in the Minnelusa aquifer was located near the structural feature of the Belle Fourche Anticline. This anticline was represented in the model as a zone of high transmissivity $\left(3,000 \mathrm{ft}^{2} / \mathrm{d}\right)$, which is several orders of magnitude greater than the surrounding area. The scale of this aquifer test stressed the formation over about $1,200 \mathrm{ft}$ from the pumped well and yielded a transmissivity equal to $9,600 \mathrm{ft}^{2} / \mathrm{d}$. Thus, this aquifer test may have tested a local area of high transmissivity in the Minnelusa Formation. The estimate of transmissivity from the aquifer test is at the same order of magnitude as the simulation-based estimate of transmissivity for the highly permeable structural feature. However, this does not imply that the transmissivity estimated from the numerical simulations is correct, considering the poorly known recharge and discharge (including springs and wells) rates.

\section{Madison Aquifer}

This section describes a numerical simulation of steady-state ground-water flow in the Madison aquifer near Spearfish. Like the numerical modeling of ground-water flow in the Minnelusa aquifer presented earlier, the simulation of ground-water flow in the Madison aquifer was intended to provide an understanding of the recharge/transmissivity relation in the study area. In addition, the numerical simulations were intended to provide insight on the role of geologic structures on ground-water movement in the Spearfish area.

\section{Model Domain, Boundary Conditions, and Parameter Values}

The model domain used to simulate groundwater flow in the Madison aquifer is shown in figure 32. Again, the domain size is considerably larger than the immediate vicinity of the City of Spearfish so that well-defined hydrologic boundaries in the Madison aquifer can be considered in the simulations. The extension of the potentiometric surface was modified from Kyllonen and Peter (1987) using waterlevel data in Wyoming.

For the purpose of explanation, the boundary of the model domain in figure 32 was marked by a series of points denoted as A, B, C, D, E, and F. These points denote segments along the boundary having different boundary conditions. Along segments A-F and B-C in figure 32 , there was assumed to be no ground-water flow perpendicular to the boundary. These segments of the boundary are approximately perpendicular to potentiometric contours; in this area of the model domain, potentiometric contours are nearly parallel to the outcrop of the Madison aquifer.

Segment D-E in figure 32 also was assumed to be a no-flow boundary because it is approximately perpendicular to potentiometric contours in the northern extent of the model domain. The potentiometric contours in this area characterize large-scale regional ground-water flow in the Madison aquifer extending from Wyoming into South Dakota (Downey, 1984).

In figure 32, segments C-D and E-F were assumed to be boundaries of fixed hydraulic head corresponding to the large-scale regional ground-water flow in the Madison aquifer. Along segment C-D, the hydraulic head was assumed to be at an elevation of $3,500 \mathrm{ft}$ above sea level, whereas along segment E-F, the hydraulic head was assumed to be $3,600 \mathrm{ft}$ above sea level.

Segment A-B in figure 32 approximates the outcrop of the Madison aquifer, and it was assumed to be a boundary where recharge was prescribed. This boundary was assumed to be the only source of groundwater recharge to the Madison aquifer in the model domain. Recharge to the Madison aquifer along this boundary is most likely the result of streamflow losses and precipitation runoff from local drainage areas. Detailed studies of these processes in the Spearfish area, however, have not been conducted. Therefore, certain assumptions regarding the magnitude and distribution of the recharge to Madison aquifer were made to facilitate ground-water simulations.

The major source of recharge to the Madison aquifer was assumed to be from streams as they cross the outcrop. Streamflow losses resulting from the diversion of Spearfish Creek through the aqueduct have been discussed in a previous section of this report. The difference between the streamflow at the two gaging stations on Spearfish Creek provided an estimate of the streamflow losses, which were assumed to recharge the Madison aquifer only. The estimated recharge to the Madison aquifer from Spearfish Creek is approximately $260,400 \mathrm{ft}^{3} / \mathrm{d}$. 


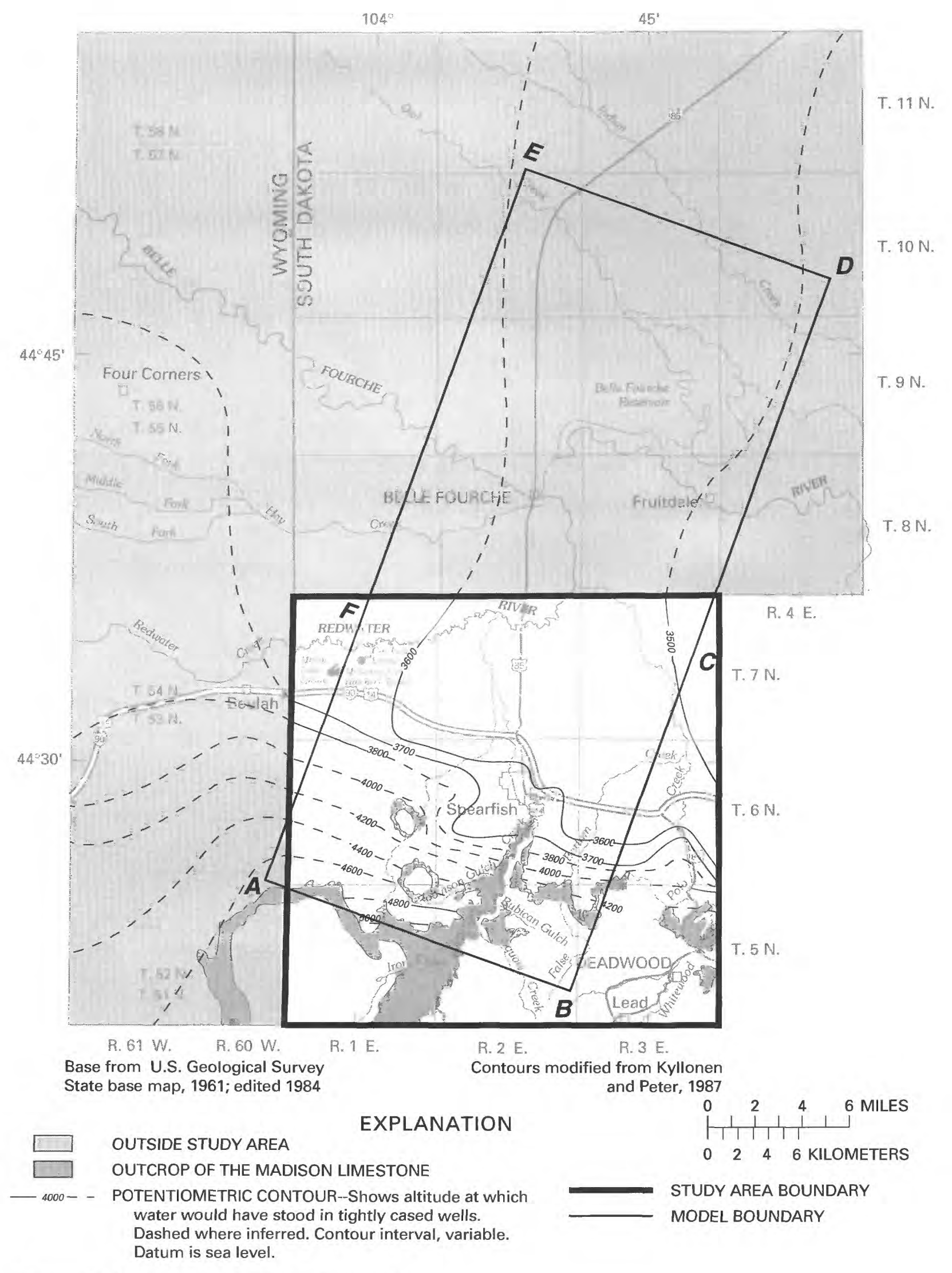

Figure 32. Model domain for the Madison aquifer. 
Losses from other streams or drainages in the modeled area (such as False Bottom Creek, Robison Gulch, Iron Creek, and possibly Higgins Gulch) also are likely to provide recharge to the Madison aquifer (fig. 32). These streams or drainages usually lose their entire flow as they cross the outcrop of the Madison Limestone. However, these streams or drainages are not gaged; therefore, estimates of the average streamflow losses need to be made for the purpose of groundwater simulations. These streams are smaller than Spearfish Creek, thus, for estimating recharge from these streams, the average recharge for each stream was assumed to be one-half of the Spearfish Creek rate or about $32,800 \mathrm{ft}^{3} / \mathrm{d}$.

Precipitation over the outcrop of the Madison Limestone also may contribute to recharge. However, in this investigation, it was assumed that the streamflow losses discussed above are the result of precipitation, and therefore, accounting for additional recharge due to precipitation was not warranted for the catchment areas associated with False Bottom Creek, Robison Gulch, and other basins. However, immediately southwest of the model domain is a large domed area in the midst of the outcrop of the Madison Limestone. In this area, it was assumed that precipitation runoff from this domed area (Citadel area) contributes to recharge of the Madison aquifer in the southwestern part of the model domain. The volumetric rate of recharge from this area was estimated using the surface area of Citadel area equal to about $31 \mathrm{mi}^{2}$, annual precipitation of $22 \mathrm{in} / \mathrm{yr}$, and approximately 3 percent of the precipitation becoming runoff and infiltrating into the Madison aquifer. Rahn and Gries (1973) estimated approximately 3 percent of precipitation on the Precambrian core in the northern Black Hills becomes recharge to the Madison aquifer. This yielded a volumetric rate of recharge equal to $130,200 \mathrm{ft}^{3} / \mathrm{d}$.

In the Spearfish area, only a few wells currently withdraw water from the Madison aquifer. However, the rates of ground-water withdrawals from these wells have been monitored continuously by the City of Spearfish. Average rates of ground-water withdrawal from the College, Dickey, Kyte, Ellingson, and Vigna wells are given in table 5. Withdrawals from the Nevin well were not considered in this investigation, because construction of this well was relatively recent and the potentiometric surface measured in the previous years would not reflect pumping from this well.
Table 5. Average ground-water withdrawals from production wells completed in the Madison aquifer in the vicinity of Spearfish, S. Dak.

\begin{tabular}{lc}
\hline Well name & $\begin{array}{c}\text { Pumping rate } \\
\text { (cubic feet per day) }\end{array}$ \\
\hline College & 9,000 \\
Dickey & 88,000 \\
Ellingson & 43,500 \\
Kyte & 1,500 \\
Vigna & 6,500 \\
\hline
\end{tabular}

There are numerous large springs, such as along tributaries to the Redwater River, that could be discharging from either, or in some combination from, the Minnelusa and Madison aquifers. For this model, it was assumed that these springs are discharging from the Madison aquifer and furthermore that the source of ground-water flow to these springs is by regional flow from outside of the model domain. Discharge from these springs was not included in simulations.

Because steady-state ground-water flow was considered, values of storativity were not required in the ground-water simulations of the Madison aquifer. However, a spatial distribution of transmissivity was needed. Based on the assumed distribution of groundwater recharge and withdrawals, the spatial distribution of the transmissivity was chosen to reproduce the general trends in the measured hydraulic heads in the Madison aquifer. The distribution of transmissivity will be discussed in detail in a subsequent section describing the results of the model simulations.

\section{Model Discretization}

For the purpose of simulating ground-water flow in the Madison aquifer, the model domain shown in figure 32 was discretized into a rectangular grid containing 34 rows and 19 columns (fig. 33). The grid cells having a cross-hatched area in figure 33 are inactive cells within the model domain. In all, there are 571 active cells in the model domain. In the southern part, each cell has an area of approximately $0.5 \mathrm{mi}^{2}$. In the northern part of the model domain, the discretization is slightly larger, with each cell having an area of approximately $1 \mathrm{mi}^{2}$. The total model area is approximately $400 \mathrm{mi}^{2}$. 


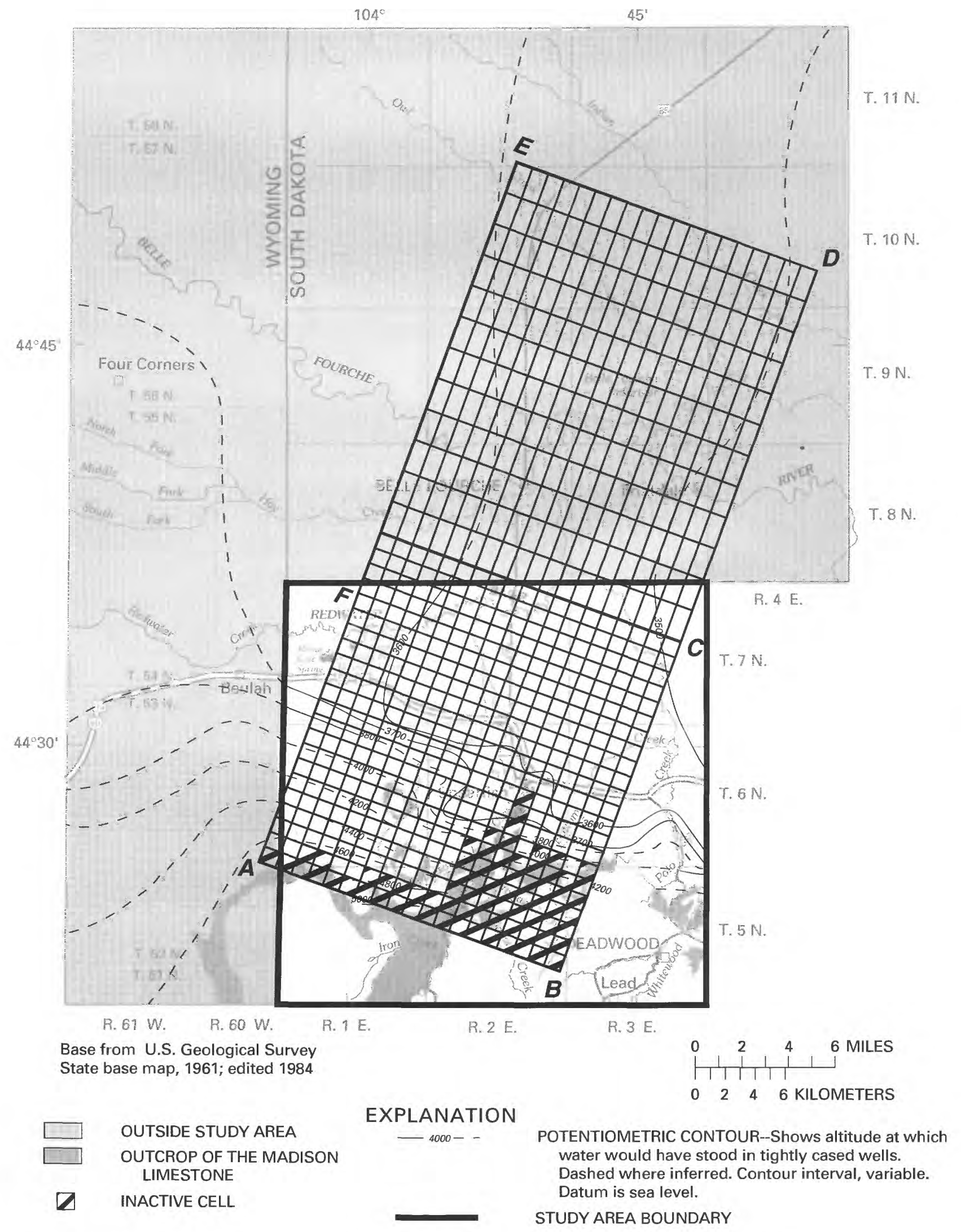

Figure 33. Finite-difference grid for numerical simulation of ground-water flow in the Madison aquifer. 
Recharge to the Madison aquifer from streamflow losses was assumed to be focused at points where streams cross the outcrop. Figure 34 shows the cells where streams were assumed to recharge the formation. Each of the streams was assumed to recharge the formation over two cells. For False Bottom Creek, Robison Gulch, and other drainages intersecting the outcrop, each cell was prescribed a volumetric recharge rate equal to $16,400 \mathrm{ft}^{3} / \mathrm{d}$. For the two cells associated with the streamflow losses from Spearfish Creek, a volumetric recharge rate equal to $130,200 \mathrm{ft}^{3} / \mathrm{d}$ was prescribed for each cell. Recharge from precipitation from Citadel area in the southwestern part of the model domain also was assumed to recharge the Madison aquifer over two cells along the modeled boundary. At each cell, a prescribed recharge of $65,100 \mathrm{ft}^{3} / \mathrm{d}$ was assumed to recharge the Madison aquifer. Groundwater withdrawals from the Madison aquifer due to pumping were prescribed at the cells corresponding to the location of the wells listed in table 5. The location of ground-water withdrawals due to pumping also is shown in figure 34 .

\section{Ground-Water Simulations}

The distribution of the transmissivity used to reproduce the measured potentiometric surface of the Madison aquifer also is shown figure 34 . The transmissivity in the vicinity of the outcrop was assumed to be lower than the transmissivity in the northern part of the model domain. The transmissivity near the outcrop was estimated to be $200 \mathrm{ft}^{2} / \mathrm{d}$ given the estimated recharge rate. Transmissivity in an area that includes the City of Spearfish and the northern part of the model domain is more than an order of magnitude larger at $7,000 \mathrm{ft}^{2} / \mathrm{d}$. With these values of transmissivity, the modeled potentiometric surface is shown in figure 35 . To the east of the City of Spearfish is False Bottom Creek, where the simulated heads are slightly lower than the measured hydraulic heads that have been interpolated in this area. The difference between the simulated heads and the measured heads could be the result of underestimating the recharge from False Bottom Creek.

The streamflow losses at False Bottom Creek were only estimates because this stream has not been gaged. Thus, the discharge associated with this stream and the streamflow losses could be larger than the estimated value. To illustrate the impact of varying streamflow recharge on model results, streamflow losses associated with False Bottom Creek were increased to $64,800 \mathrm{ft}^{3} / \mathrm{d}$ while all other withdrawals and streamflow losses in other gaged areas remained the same. Using the same distribution of transmissivity shown in figure 34 , the simulated potentiometric surface for this scenario is shown in figure 36 . The simulated hydraulic heads near False Bottom Creek are higher and more closely resemble the measured hydraulic heads.

Just because the hydraulic heads shown in figure 36 more closely resemble the measured hydraulic heads does not imply that the original estimate of the streamflow loss from False Bottom Creek was incorrect. Similar simulated hydraulic heads also could have been achieved by considering the original streamflow loss estimated and a lower transmissivity in the immediate vicinity of False Bottom Creek. Similarly, questions also can arise regarding the estimated streamflow losses at the other streams or drainages in the modeled area; these streams have not been gaged and their streamflow losses were estimated based only on a knowledge of the hydrogeology of the area. The streamflow losses from these streams also could be underestimated or overestimated in these simulations. Increasing or decreasing these streamflow losses would yield similar results.

Without better estimates of streamflow losses, and in general, better estimates of recharge to the Madison aquifer and the spatial distribution of recharge, the future development of predictive models of ground-water flow in the Spearfish area would be severely hampered. With uncertainty in estimates of recharge, there will be equal uncertainty in estimating the regional transmissivity for ground-water flow, and thus, there will be uncertainty in the management of the ground-water resources in the Madison aquifer in the Spearfish area, for example, defining suitable groundwater withdrawals from production wells.

Although there are questions concerning the estimates of the recharge to the Madison aquifer, the simulations shown in this report indicate a general spatial distribution of transmissivity that should be anticipated for the Madison aquifer. Model results are consistent with lower transmissivity near the outcrop of the Madison Limestone, and with higher transmissivity in the northern part of the modeled area. The lower transmissivity near the outcrop may be an artifact of the Madison aquifer being thinner in the vicinity of the outcrop or because the aquifer may not be completely saturated near the outcrop. Other conceptual models of spatial variation in the transmissivity may provide 


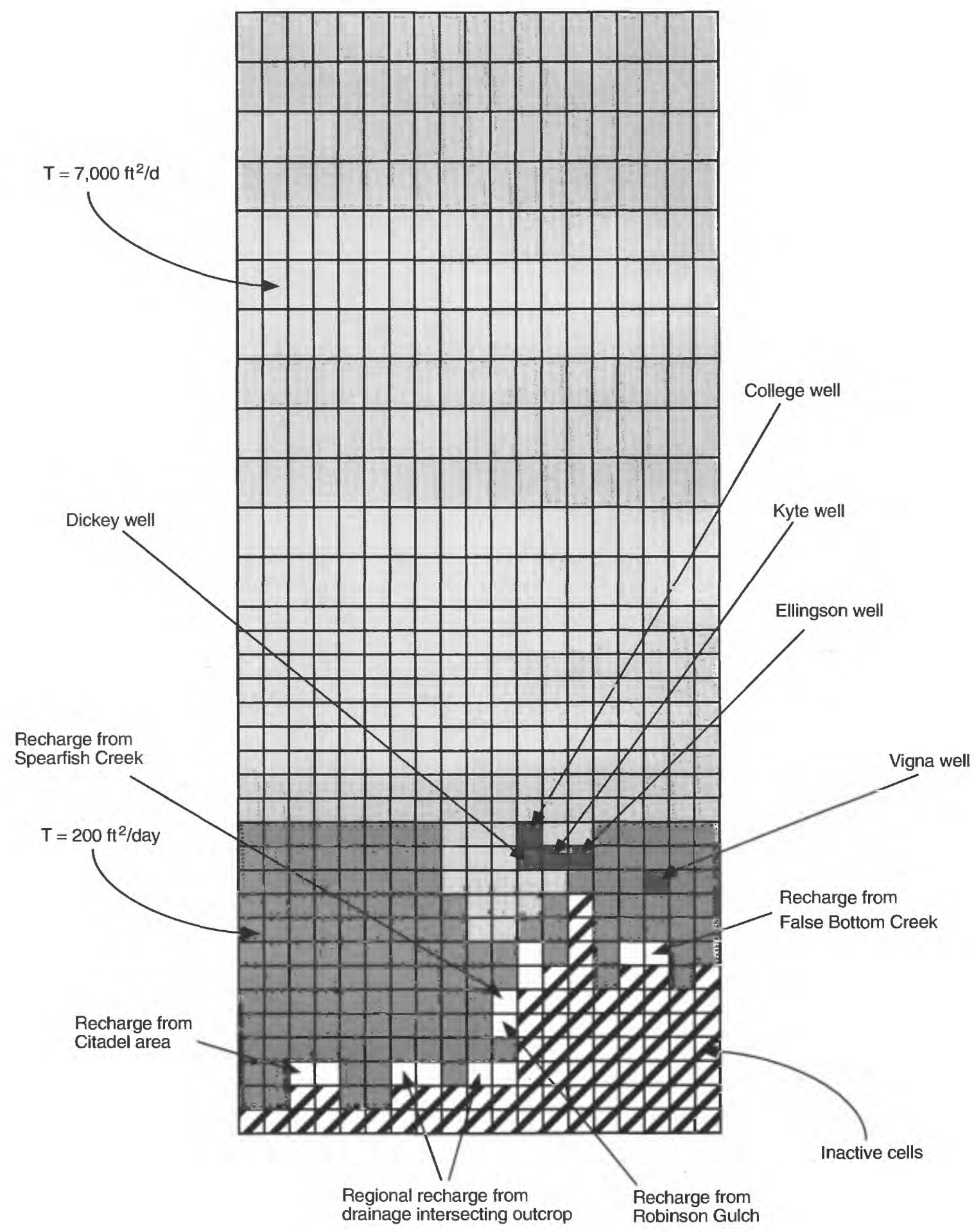

Figure 34. Distribution of recharge, ground-water pumping, and transmissivity to reproduce the measured potentiometric surface of the Madison aquifer. 

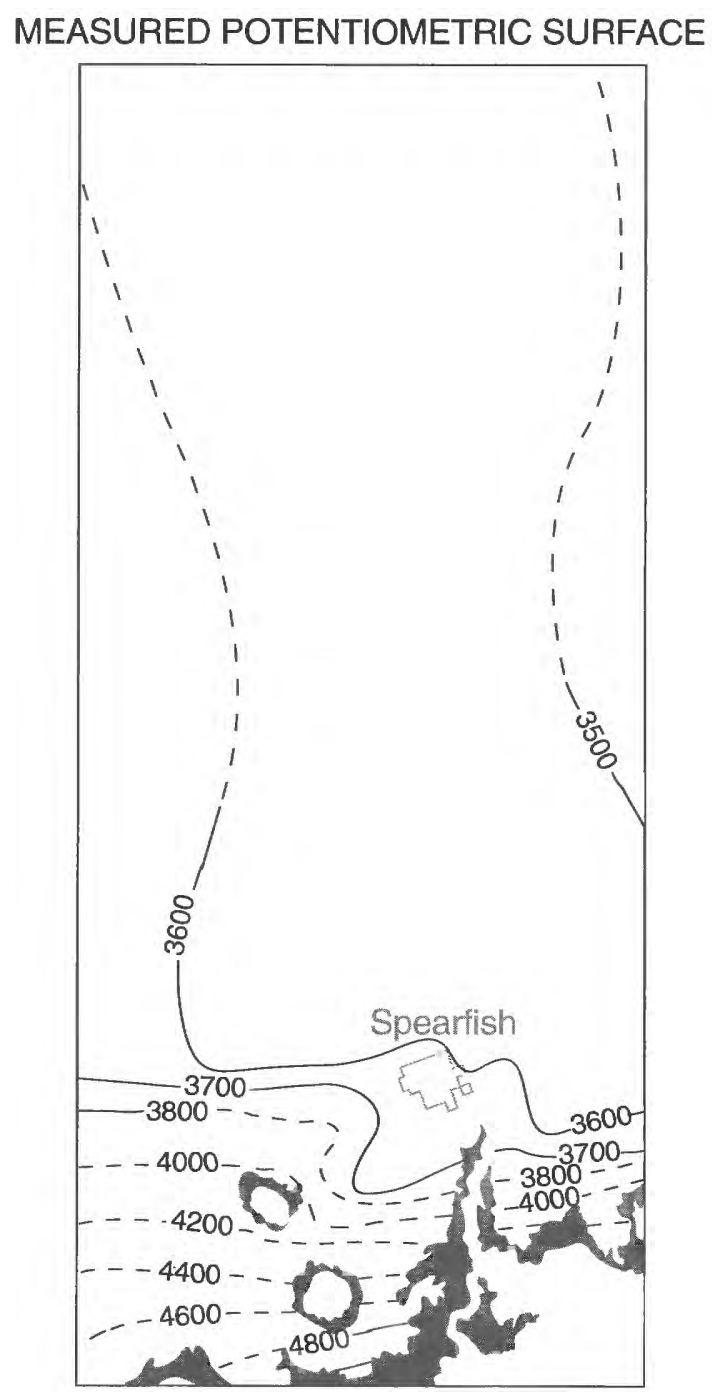

\section{SIMULATED POTENTIOMETRIC SURFACE}

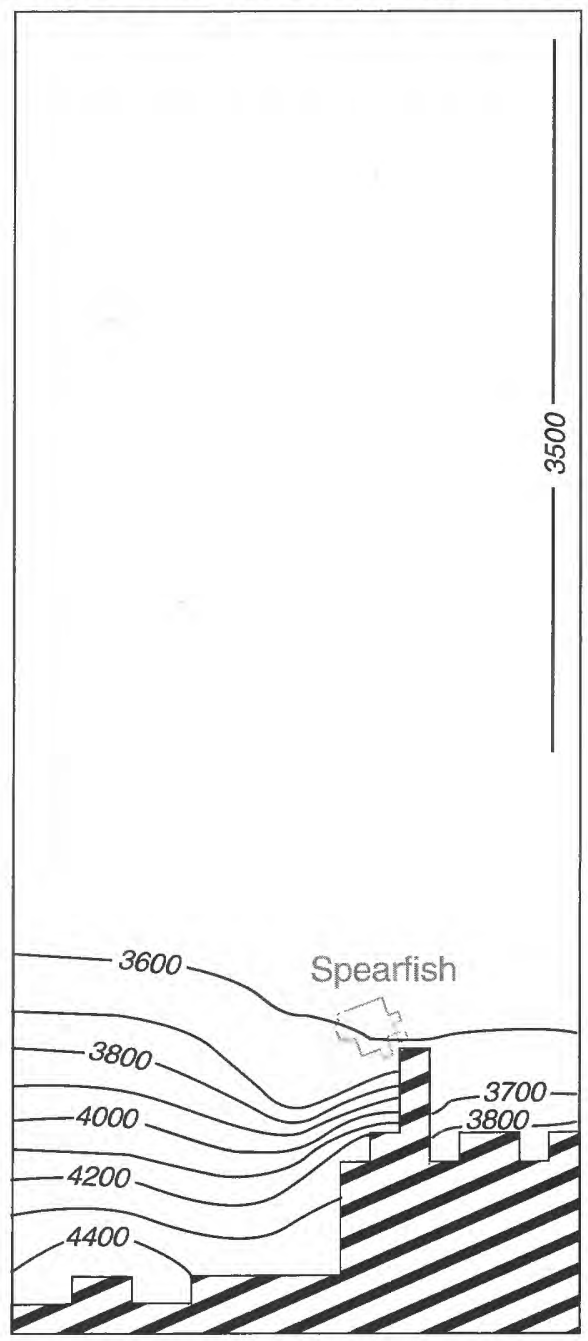

6 MILES

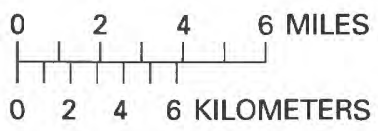

Figure 35. Comparison of the measured and simulated potentiometric surfaces for the Madison aquifer using the distribution of stream recharge, ground-water pumping, and transmissivity shown in figure 34 .

equally good results. For example, a gradual variation in the transmissivity may yield similar results and be motivated by the thickening of the formation toward the north. Furthermore, if structural features are present that affect transmissivity in the Madison aquifer, they do not show an impact on the measured potentiometric surface (fig. 11). Therefore, greater detail in the spatial variability of transmissivity cannot be inferred from the hydraulic head and current estimates of recharge.
The values of the transmissivity needed to characterize regional ground-water movement in the Madison aquifer in the Spearfish area will vary depending on the estimates of recharge and withdrawals. However, if estimates of recharge and withdrawals are reasonable, then the estimates of transmissivity from aquifer tests can be compared with those obtained from the ground-water simulations. Based on the assumed recharge and withdrawals, the values of transmissivity from the ground-water simulation represent average hydraulic properties of the 

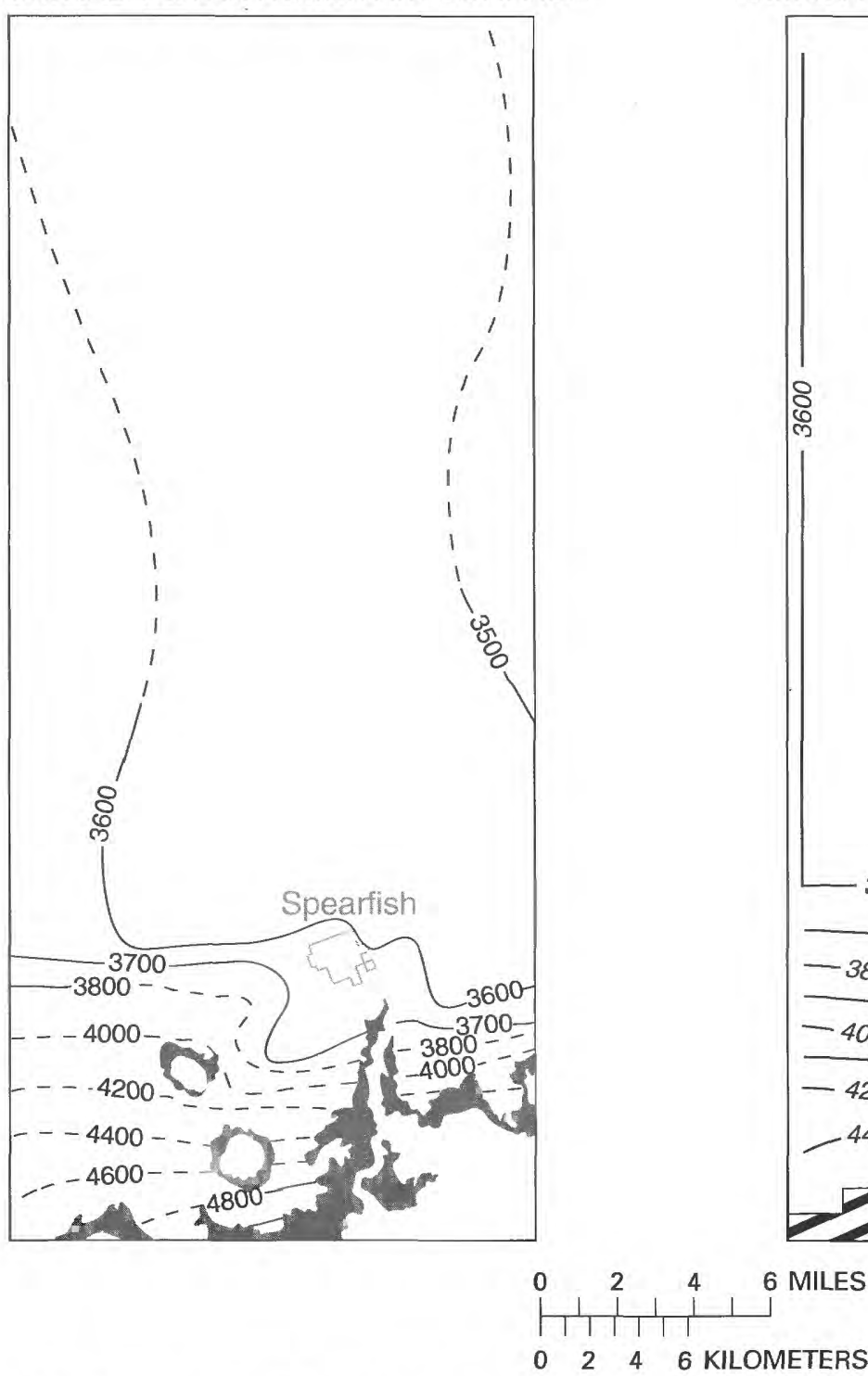

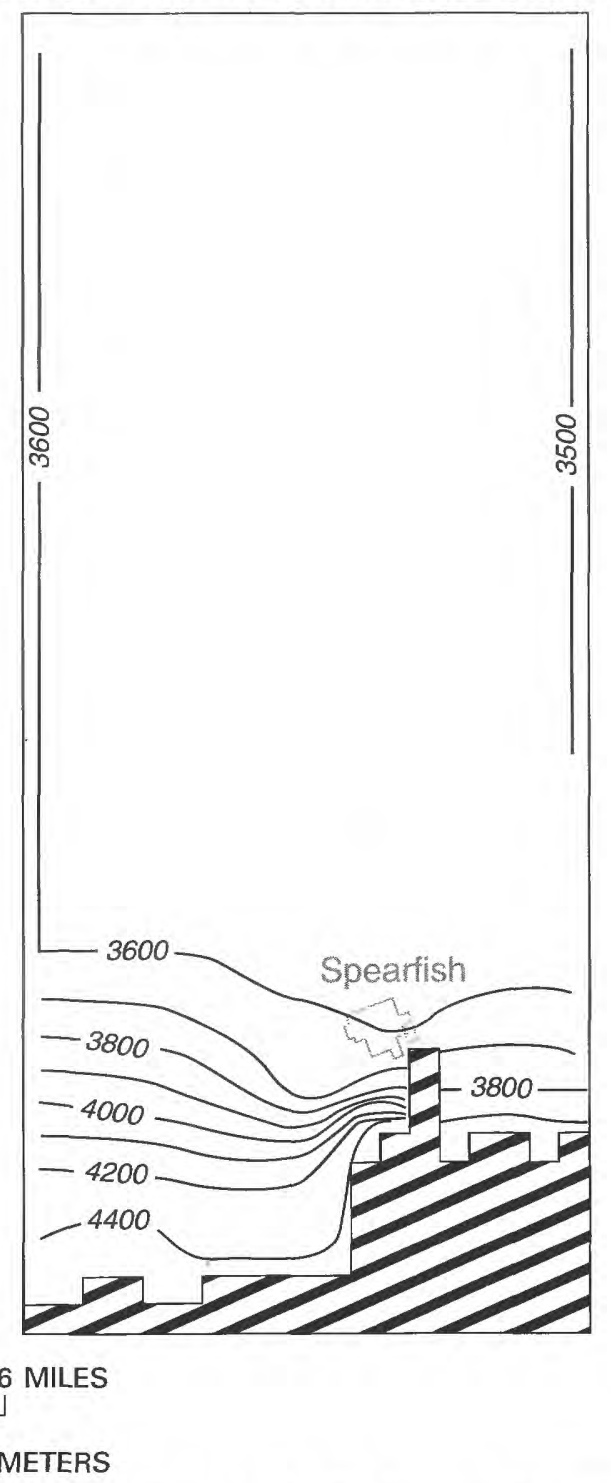

Figure 36. Comparison of the measured and simulated potentiometric surfaces for the Madison aquifer using the distribution of stream recharge, ground-water pumping, and transmissivity shown in figure 34, except with recharge from False Bottom Creek increased to 64,800 cubic feet per day.

formation that will move volumes of water in the formation to yield the measured spatial distribution of the hydraulic head. The transmissivities estimated from aquifer tests vary over several orders of magnitude, and in general, as the scale of the aquifer test increases, the transmissivity increases. However, the transmissivity from the largest scale aquifer test in the Madison aquifer is an order of magnitude larger than the regional transmissivity estimated from the numerical simulations. This does not imply that the transmissivity estimated from the numerical simulations is incorrect. The scale of the largest aquifer test only hydraulically stressed the formation over about $1,800 \mathrm{ft}$ from the pumped well and yielded a transmissivity equal to $41,700 \mathrm{ft}^{2} / \mathrm{d}$. The aquifer test may have tested a local area of the formation having high transmissivity. However, the average transmissivity associated with regional fluid movement over the scale of several miles accounts for all the high and low transmissivity areas over this larger dimension, and thus, the regional 
transmissivity is an order of magnitude lower than the transmissivity estimated from the interference test conducted in the formation.

\section{SUMMARY AND CONCLUSIONS}

The Madison aquifer in the northern Black Hills area currently is being developed as the main source of municipal water for the residents of the City of Spearfish, South Dakota. As a result of the growing population in this city, an increased demand is being placed on the ground-water resources. Because of the lack of information about the hydrogeology of the Spearfish area, the U.S. Geological Survey, in cooperation with the City of Spearfish, conducted a study to characterize the general hydrogeology of the Minnelusa and Madison aquifers in the Spearfish area. This report presents the results of a 3-year study to investigate the hydrogeology and describe the hydraulic properties of the Minnelusa and Madison aquifers near Spearfish.

The Minnelusa Formation is approximately $500 \mathrm{ft}$ thick in the study area, with the sandstones in the upper $200 \mathrm{ft}$ of the formation containing the aquifer. The lower part of the Minnelusa Formation is a confining layer or semi-confining layer separating the Minnelusa aquifer from the Madison aquifer. The altitude of the potentiometric surface of the Minnelusa aquifer ranges from about $4,000 \mathrm{ft}$ above sea level at the outcrop to $3,400 \mathrm{ft}$ above sea level north of Spearfish. Mapped structural features in the vicinity of Spearfish coincide with the low hydraulic gradient of the potentiometric surface indicating these are zones of high hydraulic conductivity.

The altitude of the potentiometric surface of the Madison aquifer ranges from about $5.000 \mathrm{ft}$ above sea level at the outcrop south of Spearfish to about 3,600 ft above sea level to the north of Spearfish. The general direction of ground-water flow is from south to north. Regionally, ground water moves north past Spearfish and then moves to the east. At the northern end of the study area, ground-water flow is from west to east. The hydraulic gradient of the Madison aquifer is the steepest near the outcrop and decreases north of Spearfish.

Temporal fluctuations in water levels at selected observation wells in the study were determined to be the direct result of recharge and withdrawals to the aquifer. Both the Minnelusa and Madison aquifers show a cyclic pattern to the changes in water level with abrupt rises in May to June corresponding to snow'melt runoff and the increase in spring precipitation. Tro effect of spring recharge is more pronounced in the Madison aquifer than in the Minnelusa aquifer.

In order to quantify rates of ground-water movement in subsurface formations, properties $o^{f}$ transmissivity and storativity need to be identified. Transmissivity, $T$, and storativity, $S$, were determined through aquifer-testing techniques that included interference tests, specific-capacity tests, and airpressurized slug tests. In addition, estimates of $T$ were made based on regional water-budget calculations using numerical models of steady-state ground-water flow in the Minnelusa and Madison aquifers.

In the Minnelusa aquifer, the $T$ and $S$ estimated from the interference test in the golf course well were $9,600 \mathrm{ft}^{2} / \mathrm{d}$ and $7.4 \times 10^{-5}$, respectively. This estimate of $T$ and $S$ was based on drawdown measured in the cbservation well LA-88B, located 1,200 ft from the purped well. In comparison, the transmissivity estimates from air-pressurized slug tests conducted in wells LA-87A, LA-88B, and LA-88A were more than an order of magnitude less, ranging from 125 to $396 \mathrm{ft}^{2} / \mathrm{d}$. The estimate of $S$ from air-pressurized slug tests conducted in wells LA-88B and LA-88A are about four orders of magnitude less. The difference in $T$ and $S$ from the slug tests and the interference test illustrates the heterogeneity present in the Minnelusa aquifer. The interference test conducted in the golf course well stressed a volume large enough to include structurally induced high-permeability zones in the Minnelusa aquifer, whereas the slug tests hydraulically stressed only a small volume of the formation and did not test the highpermeability pathways in the Minnelusa aquifer. Thus, the estimates of $T$ from air-pressurized slug tests are representative of a few tens of feet around the tested wells, and these estimates of $T$ are not applicable when considering larger scale ground-water flow in the Minnelusa aquifer.

Transmissivity estimated from aquifer tests conducted in the Madison aquifer showed a similar effect due to the scale of the formation stressed $b_{\text {y. }}$ the particular aquifer test. The transmissivity estimated from the interference test at the Dickey well was $41,700 \mathrm{ft}^{2} / \mathrm{d}$. This transmissivity estimate was based on drawdown measured in the Kyte well, located $1,800 \mathrm{ft}$ from the pumped well. In comparison, the transmissivity estimates from specific-capacity te ts ranged from 2,900 to $22,700 \mathrm{ft}^{2} / \mathrm{d}$. The transmissivity estimated from the specific-capacity test in the Dickey 
well $\left(5,100 \mathrm{ft}^{2} / \mathrm{d}\right)$ was about one order of magnitude less than the transmissivity estimated from the interference test $\left(41,700 \mathrm{ft}^{2} / \mathrm{d}\right)$. This difference illustrates the heterogeneity present in the Madison aquifer. The Dickey well may be located in a lower permeability area of the formation, whereas the drawdown at the Kyte well provides information about the hydraulic characteristics of the formation over larger distances. Furthermore, the transmissivity of the Madison aquifer estimated from an air-pressurized slug test conducted at LA-88C is several orders of magnitude less than either specific-capacity tests or the interference test. This illustrates that slug tests, which hydraulically stress only a small volume of the formation, do not test the high-permeability fractures or solutional openings in the Madison aquifer.

Numerical simulation of steady-state groundwater flow in the Minnelusa and Madison aquifers was conducted to provide an understanding of the relation between recharge and transmissivity in these aquifers in the study area. In addition, the numerical simulations provided insight on the role of geologic structures on ground-water movement in the Spearfish area.

Using estimated values of recharge and groundwater withdrawals for the Minnelusa aquifer, the general characteristics of the measured potentiometric surface could be reproduced by using a distribution of the transmissivity that varied over several orders of magnitude. The simulated transmissivity near the outcrop was assigned as $50 \mathrm{ft}^{2} / \mathrm{d}$, and increased in successive bands to a transmissivity zone of $3,000 \mathrm{ft}^{2} / \mathrm{d}$ in the northern part of the model domain. In order to obtain the spatial variations in the potentiometric surface measured in the Minnelusa aquifer, high-transmissivity zones $\left(1,000\right.$ to $\left.3,000 \mathrm{ft}^{2} / \mathrm{d}\right)$ representing the location of the mapped structural features near Spearfish were used in the simulation. In addition, a zone of low transmissivity (five orders of magnitude less than the hightransmissivity structural features) was included.

Recharge rates and withdrawals used in the simulation of hydraulic head in the Minnelusa aquifer were only estimates because investigations to quantify recharge and discharge in the study area have not been conducted. Thus, the actual recharge rates to the aquifer could be larger or smaller than the estimated values used in the simulations. Because recharge rates are not known precisely, the measured potentiometric surface can be reproduced with different recharge rates provided that transmissivity is adjusted accordingly. This illustrates that the absolute values of the transmissivity needed to characterize regional groundwater movement in the Minnelusa aquifer in the Spearfish area depend on the estimates of recharge. Thus, accurate estimates of recharge are important to produce a ground-water flow model that will accurately predict regional ground-water flow in the Spearfish area.

Using the streamflow losses and ground-water withdrawals that were estimated for the Madison aquifer, a simple spatial distribution in transmissivity generally reproduced the characteristics of the measured potentiometric surface. The s'mulated transmissivity near the outcrop, an area that includes the City of Spearfish, was estimated to be $270 \mathrm{ft}^{2} / \mathrm{d}$, while the transmissivity toward the northern part of the model domain was estimated to be an order of magnitude larger $\left(7,000 \mathrm{ft}^{2} / \mathrm{d}\right)$.

As was illustrated with the simulations of the Minnelusa aquifer, the measured hydraulic heads in the Madison aquifer could be simulated by changing the ratio of streamflow-loss recharge and the corresponding estimates of transmissivity. W $\mathrm{T}$ ithout better estimates of streamflow losses, and in ganeral, better estimates of the spatial distribution of recharge to the Minnelusa and Madison aquifers, the future development of predictive models of ground-water flow in the Spearfish area will be severely hampered.

In order for water managers to define suitable ground-water withdrawals for future production wells, further studies are important to define and quantify the spatial distribution of recharge. With uncertainty in estimates of recharge, there will be uncertainty in the volume of ground water available for withdrawals, and there will be uncertainty in estimating the transmissivity needed to predict ground-water flow.

\section{REFERENCES}

Barenblatt, G.E., Zheltov, I.P., and Kochina, I.N., 1960, Basic concepts in the theory of seepage of homogeneous liquids in fissured rocks: Journal of Applied Mathematics and Mechanics, v. 24, p. 1286-1303.

Bear, Jacob, 1979, Hydraulics of groundwater: New York, McGraw-Hill, 567 p.

Bierschenk, W.H., 1963, Determining well efficiency by multiple step-drawdown tests: International Association of Scientific Hydrology, Pub. No. 64, Symposium at Berkeley, Calif., p. 493-507. 
Blackstone, Richard, 1914, The hydro-electric power plant of the Homestake Mining Co.: Mining World and Engineering, v. 12, no. 1. p. 12-20.

Bradbury, K.R., and Rothschild, E.R., 1985, A computerized technique for estimating the hydraulic conductivity of aquifers from specific capacity data: Ground Water, v. 23 , no. 2 , p. $240-246$.

Darton, N.H., 1905, Sundance [Quadrangle], WyomingSouth Dakota: U.S. Geological Survey Atlas of the United States, Folio 127, 12 p.

Darton, N.H., and O'Harra, C.C., 1905, Aladdin [Quadrangle], Wyoming-South Dakota-Montana: U.S. Geological Survey Atlas of the United States, Folio $128,8 \mathrm{p}$.

1909, Belle Fourche [Quadrangle], South Dakota: U.S. Geological Survey Atlas of the United States, Folio 184,9 p.

Darton, N.H., and Paige, Sidney, 1925, Central Black Hills [Quadrangle], South Dakota: U.S. Geological Survey Atlas of the United States, Folio 219, $34 \mathrm{p}$.

Davis, R.W., Dyer, C.F., and Powell, J.E., 1961, Progress report on wells penetrating artesian aquifers in South Dakota: U.S. Geological Survey Water-Supply Paper $1534,100 \mathrm{p}$.

DeWitt, Ed, Redden, J.A., Wilson, A.B., and Buscher, David, 1986, Mineral resource potential and geology of the Black Hills National Forest, South Dakota and Wyoming: U.S. Geological Survey Bulletin 1580, $135 \mathrm{p}$.

Dewitt, Ed, Redden, J.A., Buscher, David, and BurackWilson, Anna, 1989, Geologic map of the Black Hills area, South Dakota and Wyoming: U.S. Geological Survey Miscellaneous Investigations Series Map I-1910, scale 1:250,000, 1 sheet.

Driscoll, D.G., and Bradford, W.L, 1994, Compilation of selected hydrologic data, through water year 1992, Black Hills Hydrology Study, western South Dakota: U.S. Geological Survey Open-File Report 94-319, $158 \mathrm{p}$.

Driscoll, D.G., Bradford, W.L., and Neitzert, K.M., 1996, Selected hydrologic data, through water year 1994, Black Hills Hydrology Study, South Dakota: U.S. Geological Survey Open-File Report 96-399, 162 p.

Downey, J.S., 1984, Geohydrology of the Madison and associated aquifers in parts of Montana, North Dakota, South Dakota, and Wyoming: U.S. Geological Survey Professional Paper 1273-G, $47 \mathrm{p}$.

Ferris, J.G., Knowles, D.B., Brown, R.H., and Stallman, R.W., 1962, Theory of aquifer tests: U.S. Geological Survey Water-Supply Paper 1536-E, p. 69-174.

Ghannam, J., and Rahn, P.H., 1994, Ground-water recharge to the Madison aquifer in the Black Hills area, South Dakota: South Dakota Academy of Science Proceedings, v. 73, p. 195-204.
Greene, E.A., 1993, Hydraulic properties of the Madison aquifer system in the western Rapid City area, Scuth Dakota: U.S. Geological Survey Water-Resources Investigations Report 93-4008, 56 p.

Greene, E.A., and Lamb, J.D., 1994, Applications of geophysical logs to characterize the hydrogeologic p"operties of a Paleozoic carbonate aquifer in the Black Hills of South Dakota: Proceedings of the 5th Annual Mineral and Geotechnical Logging Society, Tulsa, Okla., October 25-28, p. 39-50.

Greene, E.A., and Rahn, P.H., 1995, Localized anisotrcny in a karst aquifer: Ground Water, v. 33, no. 5, p. 806-816.

Greene, E.A., and Shapiro, A.M., 1995, Methods of conducting air-pressurized slug tests and computation of type curves for estimating transmissivity and storativity: U.S. Geological Survey Open-File Report 95-424, 43 p.

Gries, J.P, and Steece, F.V., 1985, Paleozoic and Mesozoic stratigraphy of the northern Black Hills, in Rich, F.J., ed., Geology of the Black Hills, South Dakota and Wyoming (2d ed.): Geological Society of America, Field Trip Guidebook, American Geological Institute, p. $175-180$.

Kruseman, G.P., and de Ridder, N.A., 1991, Analysis and evaluation of pumping test data ( $2 \mathrm{~d}$ ed.): International Institute for Land Reclamation and Improvement, Publication 47, $377 \mathrm{p}$.

Kyllonen, D.P., and Peter, K.D., 1987, Geohydrology and water quality of the Inyan Kara, Minnelusa, and Madison aquifers of the northern Black Hills, South Dakota and Wyoming, and Bear Lodge Mountain`, Wyoming: U.S. Geological Survey Water-Resources Investigations Report 86-4158, $61 \mathrm{p}$.

Lisenbee, A.L., 1985, Tectonic map of the Black Hills uplift, Montana, Wyoming, and South Dakota: State of Wyoming Geological Survey Map Series 13, scale $1: 24,000$.

Lisenbee, A.L., 1991a, Geologic map of the Deadwood North Quadrangle, Lawrence County, South Dakota: South Dakota School of Mines and Technology, scale 1:24,000.

1991b, Geologic map of the Lead Quadrangle, Lawrence County, South Dakota: South Dakota School of Mines and Technology, scale 1:24,000.

1991c, Geologic map of the Maurice Quadrangle, Lawrence County, South Dakota: South Dakota School of Mines and Technology, scale 1:24,000.

1991d, Geologic map of the Savoy Quadrangle, Lawrence County, South Dakota: South Dakota School of Mines and Technology, scale 1:24,000.

1991e, Geologic map of the Spearfish Quadrangle, Lawrence County, South Dakota: South Dakota School of Mines and Technology, scale 1:24,000. 
Lisenbee, A.L. and Redden, J.A., 1991, Geologic map of the Deadwood South Quadrangle, Lawrence County, South Dakota: South Dakota School of Mines and Technology, scale 1:24,000.

Lohman, S.W., 1972, Ground-water hydraulics: U.S. Geological Survey Professional Paper 708, 70 p.

McDonald, M.G., and Harbaugh, A.W., 1988, A modular three-dimensional finite-difference ground-water flow model: U.S. Geological Survey Techniques of WaterResources Investigations, book 6, chap. A1, 600 p.

Peter, K.D., Kyllonen, D.P., and Mills, K.R., 1988, Geologic structure and altitude of the top of the Minnelusa Formation, northeastern Black Hills, South Dakota: U.S. Geological Survey Water-Resources Investigations Report 85-4233, 1 sheet.

Rahn, P.H., 1985, Ground water stored in the rocks of western South Dakota, in Rich, F.J., ed., Geology of the Black Hills, South Dakota and Wyoming (2d ed.): Geological Society of America, Field Trip Guidebook, American Geological Institute, p. 154-180.

Rahn, P.H, Bump, V.L., and Steece, F.V., 1985, Engineering geology of the central and northern Black Hills, South Dakota, in Rich, F.J., ed., Geology of the Black Hills, South Dakota and Wyoming ( $2 \mathrm{~d}$ ed.): Geological Society of America, Field Trip Guidebook, American Geological Institute, p. 135-153.
Rahn, P.H., and Gries, J.P., 1973, Large springs in the Black Hills, South Dakota and Wyoming: South Dakota State Geological Survey Report of Investigations 107, 46 p.

Rorabaugh, M.I., 1953, Graphical and theoretical analysis of step-drawdown test of artesian well: Proceedings of the American Society of Civil Engineers, v. 79, separate no. 362,23 p.

Shapiro, A.M. and Greene, E.A., 1995, Inte-pretation of prematurely terminated air-pressurized slug tests: Ground Water, v. 33, no. 4. p. 539-546.

Shapiro, L.H., and J.P. Gries, 1968, Ore depc sits in Paleozoic rocks, northern Black Hills, South Dakota: Wyoming Geological Association Guidebook, $2 \mathrm{C}^{\prime} \mathrm{h}$ Field Conference, p. 179-185.

Stallman, R.W., 1971, Aquifer-test, design, observation and data-analysis: U.S. Geological Survey Techniques of Water-Resources Investigations, book 3, chap. B1, $26 \mathrm{p}$.

Streltsova, T.D., 1988, Well testing in heterogeneous formations: New York, John Wiley and Son`, 413 p.

Theis, C.V., 1935, The relation between the lowering of the piezometric surface and the rate and d uration of discharge of a well using ground-water storage: Transactions of the American Geophysical Union, v. 16, p. $19-524$. 
SUPPLEMENTAL INFORMATION 
Table 6. Data for interference test at golf course well

[Pumping rate of production well $=220$ gallons per minute. Distance from production well $=1.200$ feeet]

\begin{tabular}{|c|c|}
\hline $\begin{array}{l}\text { Production well golf course } \\
\text { Pumping rate }(Q)=220 \text { gallons per minute }\end{array}$ & $\begin{array}{l}\text { Observation well LA-88B } \\
\text { Distance from production well }(r)=1,200 \text { feet }\end{array}$ \\
\hline $\begin{array}{l}\text { Elapsed time } \\
\text { (minutes) }\end{array}$ & $\begin{array}{l}\text { Drawdown } \\
\text { (feet) }\end{array}$ \\
\hline 2 & 0.02 \\
\hline 3 & .04 \\
\hline 4 & .09 \\
\hline 5 & .12 \\
\hline 6 & .14 \\
\hline 7 & .16 \\
\hline 8 & .19 \\
\hline 9 & .20 \\
\hline 10 & .23 \\
\hline 12 & .28 \\
\hline 15 & .32 \\
\hline 20 & .40 \\
\hline 25 & .47 \\
\hline 30 & .52 \\
\hline 35 & .56 \\
\hline 40 & .61 \\
\hline 45 & .66 \\
\hline 55 & .74 \\
\hline 65 & .82 \\
\hline 153 & 1.17 \\
\hline 250 & 1.36 \\
\hline 350 & 1.46 \\
\hline 451 & 1.53 \\
\hline 770 & 1.60 \\
\hline 1,085 & 1.78 \\
\hline 1.095 & 1.79 \\
\hline 1,455 & 1.83 \\
\hline 1,955 & I.97 \\
\hline 2,456 & 2.03 \\
\hline 2,475 & 2.05 \\
\hline
\end{tabular}


Table 7. Data for air-pressurized slug test at observation well LA-87B

\begin{tabular}{|c|c|}
\hline $\begin{array}{l}\text { Elapsed time } \\
\text { (seconds) }\end{array}$ & $\begin{array}{c}\text { Change in head from static conditi-ns } \\
\text { divided by static head } \\
\left(H / H_{o}\right)\end{array}$ \\
\hline 6 & 0.97 \\
\hline 15 & .90 \\
\hline 24 & .73 \\
\hline 33 & .69 \\
\hline 42 & .65 \\
\hline 51 & .62 \\
\hline 60 & .60 \\
\hline 69 & .58 \\
\hline 85 & .54 \\
\hline 107 & .50 \\
\hline 116 & .48 \\
\hline 128 & .46 \\
\hline 146 & .44 \\
\hline 167 & .42 \\
\hline 176 & .40 \\
\hline 194 & .38 \\
\hline 215 & .37 \\
\hline 250 & .34 \\
\hline 281 & .32 \\
\hline 311 & .30 \\
\hline 371 & .27 \\
\hline 430 & .25 \\
\hline 491 & .22 \\
\hline 550 & .21 \\
\hline 611 & .19 \\
\hline 670 & .18 \\
\hline 926 & .15 \\
\hline 111 & .13 \\
\hline 138 & .11 \\
\hline 240 & .07 \\
\hline 360 & .05 \\
\hline 516 & .03 \\
\hline 636 & .02 \\
\hline 755 & .02 \\
\hline
\end{tabular}


Table 8. Data for air-pressurized slug tests at observation well LA-88B for applied pressures of 5,12 , and 30 pounds per square inch

\begin{tabular}{cccc}
\hline $\begin{array}{c}\text { Elapsed time } \\
\text { (seconds) }\end{array}$ & \multicolumn{3}{c}{ Change in head from static conditions divided by static head $\left(\boldsymbol{H} / \boldsymbol{H}_{\mathrm{o}}\right)$} \\
\cline { 2 - 4 } & $\begin{array}{c}\text { 5 pounds per } \\
\text { square inch }\end{array}$ & $\begin{array}{c}\text { 12 pounds per } \\
\text { square inch }\end{array}$ & $\begin{array}{c}\text { 30 pounds per } \\
\text { square inch }\end{array}$ \\
\hline 1 & -- & 0.95 & 0.93 \\
2 & 0.89 & .88 & .95 \\
3 & .77 & .80 & .89 \\
4 & .68 & .73 & .84 \\
5 & .57 & .66 & .80 \\
6 & .49 & .59 & .75 \\
7 & .41 & .53 & .71 \\
8 & .34 & .48 & .67 \\
9 & .27 & .42 & .63 \\
10 & .22 & .37 & .59 \\
12 & .13 & .28 & .52 \\
15 & .04 & .18 & .42 \\
20 & -- & .06 & .29 \\
25 & -- & .002 & .18 \\
30 & -- & -- & .10 \\
35 & -- & -- & .04 \\
40 & - & - & .01 \\
45 & -- & - & .002 \\
\hline
\end{tabular}


Table 9. Data for air-pressurized slug tests at observation well LA-88A for 100, 61, and 43 percent of the equilibrium water level, using an applied air pressure of 5 pounds per square inch

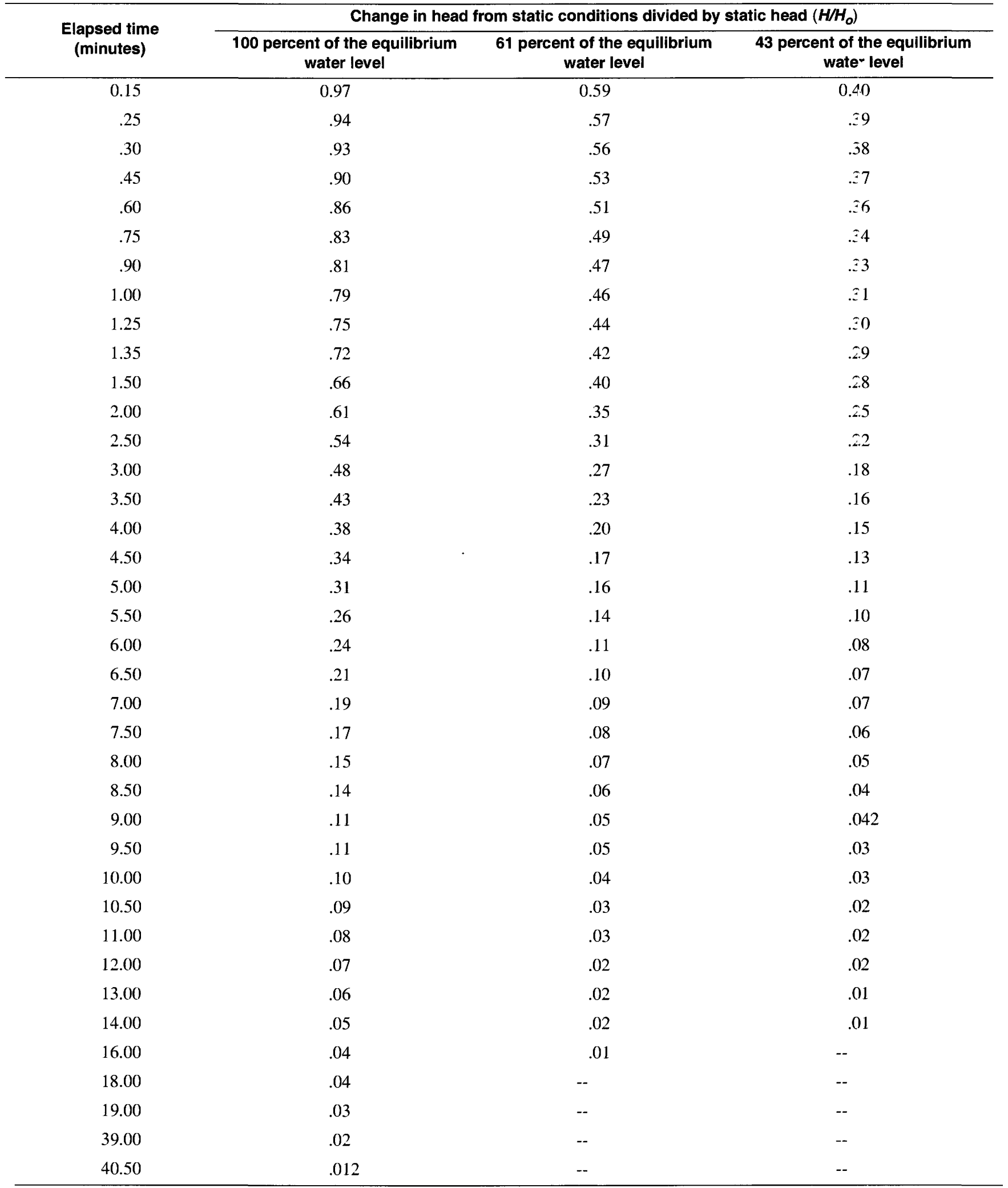


Table 10. Data for interference test at Dickey well

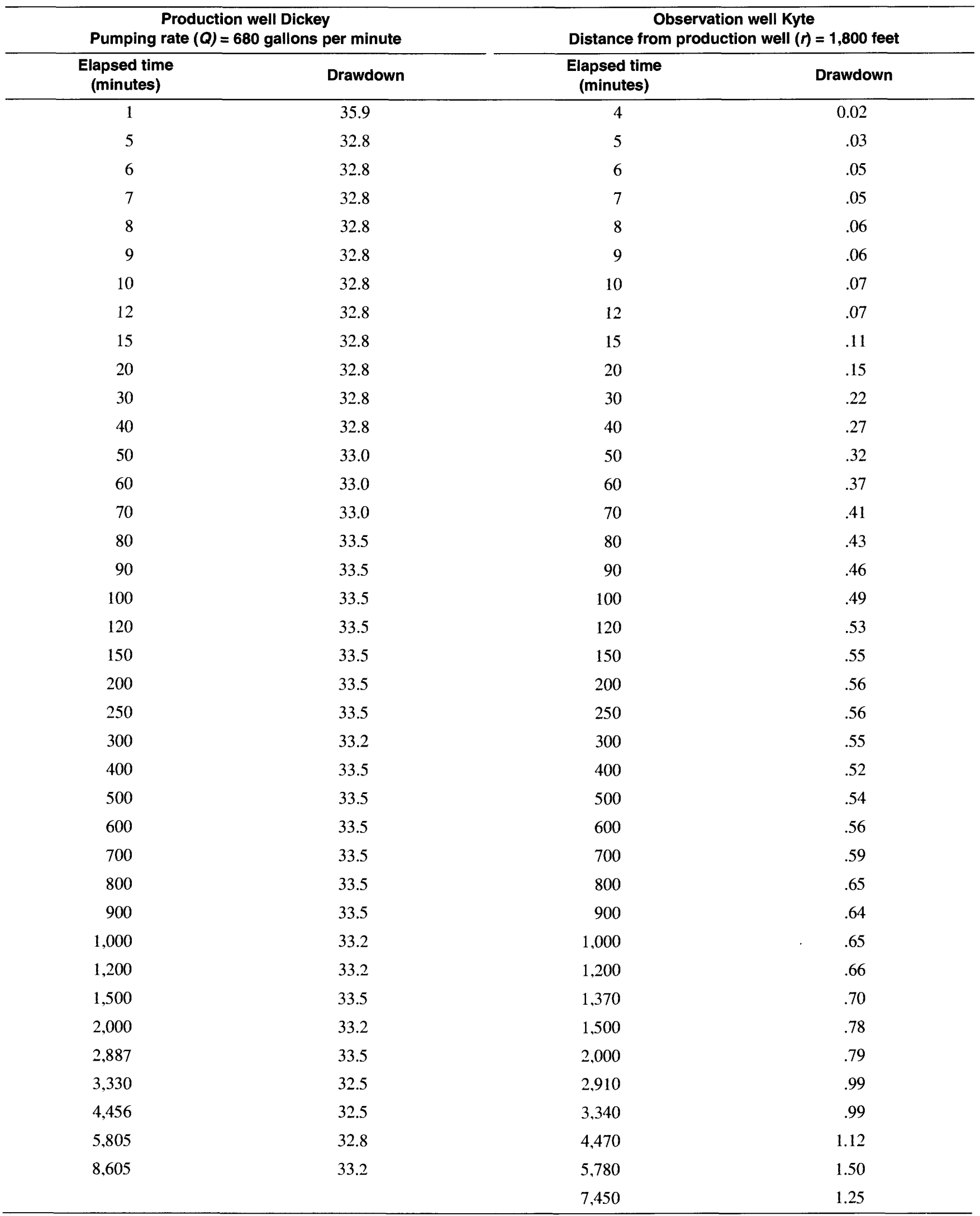


Table 11. Data for air-pressurized slug tests at observation well LA-88C for 87 and 56 percent of the equilit rium water level, using an applied air pressure of 4.1 pounds per square inch

\begin{tabular}{|c|c|c|c|}
\hline \multirow{2}{*}{$\begin{array}{l}\text { Elapsed time } \\
\text { (minutes) }\end{array}$} & $\begin{array}{c}\text { Change in head from static conditions } \\
\text { divided by static head } \\
\left(H / H_{o}\right)\end{array}$ & \multirow{2}{*}{$\begin{array}{l}\text { Elapsed time } \\
\text { (minutes) }\end{array}$} & \multirow{2}{*}{$\begin{array}{c}\begin{array}{c}\text { Change in head from static conditions } \\
\text { divided by static head } \\
\left(H / H_{0}\right)\end{array} \\
56 \text { percent of the equilibrium } \\
\text { water level }\end{array}$} \\
\hline & $\begin{array}{c}87 \text { percent of the equilibrium } \\
\text { water level }\end{array}$ & & \\
\hline 1 & 0.86 & 1.3 & 0.55 \\
\hline 2 & .85 & 1.5 & .54 \\
\hline 4 & .84 & 2 & .53 \\
\hline 5 & .83 & 2.5 & .53 \\
\hline 6 & .81 & 3 & .52 \\
\hline 8 & .80 & 4 & .51 \\
\hline 11 & .80 & 5 & .50 \\
\hline 13 & .77 & 6 & .49 \\
\hline 17 & .75 & 8 & .48 \\
\hline 22 & .74 & 10 & .47 \\
\hline 27 & .70 & 12 & .46 \\
\hline 32 & .68 & 15 & .45 \\
\hline 37 & .65 & 17 & .43 \\
\hline 42 & .63 & 20 & .41 \\
\hline 52 & .60 & 25 & .39 \\
\hline 62 & .58 & 30 & .38 \\
\hline 82 & .54 & 35 & .36 \\
\hline 102 & .49 & 40 & .34 \\
\hline 122 & .43 & 50 & .32 \\
\hline 152 & .38 & 60 & .29 \\
\hline 177 & .33 & 69 & .27 \\
\hline 202 & .28 & 82 & .24 \\
\hline 302 & .24 & 100 & .22 \\
\hline 407 & .20 & 120 & .20 \\
\hline 527 & .14 & 150 & .16 \\
\hline 582 & .08 & 175 & .14 \\
\hline 667 & .06 & 225 & .10 \\
\hline 827 & .05 & 300 & .07 \\
\hline 927 & .04 & 400 & .04 \\
\hline
\end{tabular}

